\title{
Judicial Resolution of Nonconsensual Pornography Dissemination Cases
}

\author{
ERIC GOLDMAN* \& ANGIE JIN**
}

\section{CONTENTS}

I. MAPPING THE OBSERVABLE UNIVERSE ................................... 286

II. THE COMPILATION TAXONOMY .............................................291

III. ANALYSIS OF THE COMPILATION …………................................. 294

A. Demographics ..................................................................... 294

B. Claims Analysis ................................................................. 297

C. Remedies Analysis .............................................................. 302

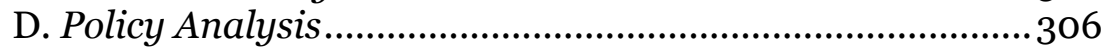

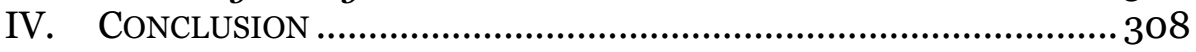

APPENDIX A: OFFLINE DISSEMINATION ………….............................. 309

APPENDIX B: ONLINE DISSEMINATION …………….......................... 312

APPENDIX C: THREATENED DISTRIBUTION ........................................ 332

APPENDIX D: ACTIONS AGAINST INTERMEDIARIES.............................. 345

Americans are creating and sharing historically unprecedented amounts of homemade non-commercial sexually explicit photos and videos-likely billions of pornographic items every year. ${ }^{1}$ Millions of

\footnotetext{
* Professor of Law, Santa Clara University School of Law. http://www.ericgoldman.org. egoldman@gmail.com. Thanks to Colleen Chien, Jason Farnon, Andrew Gilden, Bennet Kelley, Karl Kronenberger, Laura Schrauth, Scott Stroud, and the participants at the Santa Clara University School of Law Faculty Workshop for their comments.

${ }^{* *}$ J.D. May 2016, Cornell Law School.

${ }^{1}$ To get a sense of scale, see Sext Much? If So, You're Not Alone, ScI. AM., https://www.scientificamerican.com/article/sext-much-if-so-youre-not-alone [https://perma.cc/BU5F-5ZRY] (last visited Mar. 17, 2017) for a 2014 study that found
} 
Americans have had their private pornographic materials disseminated (or threatened to be disseminated) without their consent, ${ }^{2}$ and such nonconsensual dissemination can lead to serious and potentially life-altering consequences for victims. 3 Due to the volume and severity of the problems it creates, the dissemination of nonconsensual pornography (sometimes called "involuntary" pornography or "revenge" pornography) 4 has emerged as one of the key social issues of the digital age.

The widely held view is that our legal system does not sufficiently deter and punish the dissemination of nonconsensual pornography. 5 For example, when introducing the Intimate Privacy Protection Act of 2016, ${ }^{6}$ Rep. Jackie Speier said:

fifty-four percent of survey participants had shared intimate content, and How Common Is Sexting?, AM. PSYCHOL. ASs'N (Aug. 8, 2015),

http://www.apa.org/news/press/releases/2015/o8/common-sexting.aspx

[https://perma.cc/E47R-ZYNG] where $88 \%$ of survey participants shared intimate content.

${ }^{2}$ One study found that roughly 10.4 million Americans have been victims of threats or posts of such images without their permission. Amanda Lenhart et al., Nonconsensual Image Sharing: One in 25 Americans Has Been a Victim of "Revenge Porn", DATA AND SOC'Y RES. INST. (Dec. 13, 2016),

https://datasociety.net/pubs/oh/Nonconsensual_Image_Sharing_2016.pdf [https://perma.cc/U98M-TPAM].

3 In one study, ninety-three percent of victims said they suffered "significant emotional distress"; eighty-two percent claimed "significant impairment in social, occupational, or other important areas of functioning" due to being a victim; fifty-one percent had suicidal thoughts due to being a victim; and forty-one percent sought psychological services. CCRI's 2013 Nonconsensual Pornography (NCP) Research Results, CYBER CIVIL RIGHTS INITIATIVE, https://www.cybercivilrights.org/wp-content/uploads/2016/11/NCP-2013Study-Research-Results-1.pdf [https://perma.cc/68LC-M8RC].

4 Although "revenge porn" is often considered the generic term, we adopt the term "nonconsensual pornography" consistent with guidance from the Cyber Civil Rights Initiative: 'The term 'revenge porn,' though frequently used, is somewhat misleading. Many perpetrators are not motivated by revenge or by any personal feelings toward the victim. A more accurate term is nonconsensual pornography (NCP), defined as the distribution of sexually graphic images of individuals without their consent." See What is Revenge Porn?, CYBER CIVIL RIGHTS INITIATIVE, https://www.cybercivilights.org [https://perma.cc/TUY6-WFGB].

5 E.g., Erik Ortiz, Marines Photo Scandal: What Can Revenge Porn Victims Do?, NBC NEwS, (Mar. 10, 2017), http://www.nbcnews.com/news/us-news/marines-photo-scandalwhat-can-revenge-porn-victims-do-n731241 [https://perma.cc/M8US-G5FV].

${ }^{6}$ H.R. 5896, 114th Cong. (2d Sess. 2016). 
What makes these acts even more despicable is that many predators have gleefully acknowledged that the vast majority of their victims have no way to fight back. Celebrities and other high-profile victims might be able [to] take on these predators in civil courts, but the average person can't afford that option. Even more disturbing is the number of victims who have mustered the courage and strength to pursue criminal charges, only to learn there is no law that protects them.7

Based on the perceived insufficiency of existing law, states have enacted (or are considering) dozens of new "sui generis" laws to fill the purported gaps in the existing legal rules. Congress, too, is considering its options. The Intimate Privacy Protection Act did not pass Congress, but Rep. Speier and others have again proposed a new federal sui generis bill. ${ }^{8}$

Rep. Speier's statement, echoed by so many other commentators, raises significant questions about how much anti-nonconsensual pornography enforcement is actually taking place. Unfortunately, attempts to answer such questions are plagued by "a real data problem."9

As a step towards understanding the scope of existing enforcement activity, this article takes a snapshot of the "observable universe" of nonconsensual pornography enforcement actions. We compiled eighty-nine nonconsensual pornography dissemination enforcement actions dating from 1984 to the end of 2016. Some of these enforcement actions have received substantial media coverage; many others are obscure or were not previously publicized. As we will explain in some detail, our compilation is almost certainly a small subset of the actual universe of enforcement actions that have been brought. Nevertheless, we think additional insights into what

\footnotetext{
7 Press Release, Congresswoman Speier, Fellow Members of Congress Take on

Nonconsensual Pornography, AKA Revenge Porn, CONGRESSWOMAN JACKIE SPEIER (July 14, 2016), https://speier.house.gov/media-center/press-releases/congresswoman-speierfellow-members-congress-take-nonconsensual [https://perma.cc/3244-F36D].

8 Ending Nonconsensual Online User Graphic Harassment Act of 2017, H.R. 4472 \& S. 2162, 115th Cong. (1st Sess. 2017).

9 Emily Reynolds, Why There's No 'Silver Bullet' for Ridding the Web of Revenge Porn, WIRED, (Mar. 16, 2017), http://www.wired.co.uk/article/revenge-porn-facebook-socialmedia [https://perma.cc/5LLT-W43N] (quoting Prof. Mary Anne Franks).
} 
enforcement actions actually have been brought-and how they faredshould help inform ongoing deliberations about the regulatory infrastructure needed to effectively address nonconsensual pornography dissemination.

The article proceeds in three parts. Part I describes our compilation and its limitations. Part II explains the compilation's taxonomy. Part III analyzes the compilation. The compilation is presented in four appendices.

\section{MAPPING THE OBSERVABLE UNIVERSE ${ }^{10}$}

To examine the widespread skepticism about the regulations on nonconsensual pornography dissemination, we endeavored to measure as much as possible of the "observable universe" of enforcement actions involving nonconsensual pornography dissemination. This part will explain our compilation efforts and the differences between the observable and unobservable universes.

Universe Scope. The term "nonconsensual pornography" describes a wide range of activities. ${ }^{11}$ We focused only on one type of activity: the nonconsensual dissemination of non-commercial pornography, irrespective of whether the pornography was created or shared consensually. In virtually all of the compiled cases, the disseminator was motivated by "revenge," harassment, extortion or similar objectives, instead of a goal of catering to viewers' sexual interest. In addition to paradigmatic cases of "revenge porn," our compilation includes cases involving stolen pornography and model photo shoots gone wrong.

We excluded the following from our compilation:

\footnotetext{
${ }^{10}$ Where we refer to a case by a single name, the case is summarized in the appendices.

${ }^{11}$ In particular, nonconsensual pornography includes the nonconsensual creation of explicit photos or videos, whether or not the materials are disseminated further. For more discussion about the nomenclature problems and the wide range of anti-social behavior often semantically grouped together, see Eric Goldman, The Sex Tape Problem....and a Possible Legislative Solution?, TECH. \& MKTG. L. BLOG (July 11, 2008), http://blog.ericgoldman.org/archives/2008/o7/the_sex_tape_pr.htm [https://perma.cc/NW78-YCUU]; see also Scott R. Stroud \& Jonathan A. Henson, Social Media, Online Sharing, and the Ethical Complexity of Consent in Revenge Porn, THE DARK Side OF SOCIAL MEDia: A CONSUMER PSyChology PERSPECTIVE 13 (Angeline C. Scheinbaum ed. 2017).
} 
- Actions over the nonconsensual creation of pornography that was not disseminated (or threatened to be disseminated) to any third parties, such as voyeurism cases.

- Actions over the nonconsensual secondary dissemination of commercial pornography, such as infringement of a commercial pornographer's copyright.

- "Virtual" pornography cases, such as cases involving "photoshopped" images..$^{12}$

- Child pornography cases, including cases involving sexting by minors. Child pornography nominally fits within the compilation's scope because its creation and dissemination are, by definition, always nonconsensual. However, child pornography cases are voluminous, and they have been the subject of extensive analysis. Nevertheless, we included cases involving depictions of minors where we believed the dissemination was not done for viewers' sexual gratification.

- "Collateral" lawsuits prompted by an adverse consequence attributable to an actual or alleged dissemination of nonconsensual pornography. ${ }^{13}$ Examples include:

- malicious prosecution or similar claims against a government actor for an allegedly unlawful arrest, investigation or prosecution. ${ }^{14}$

- an employee suing for wrongful termination when the termination responded to the employee's threat to disseminate nonconsensual pornography of a coworker. ${ }^{15}$

\footnotetext{
${ }^{12}$ See, e.g., Ali v. Facebook, Inc., No. 4:14-cv-03066 (S.D. Tex. Oct. 24, 2014).

${ }^{13}$ However, if the underlying dissemination created an enforcement action with a substantive result, we included that action in our compilation. For example, we included Boschette because it produced a substantive ruling on the nonconsensual pornography legal questions before the malicious prosecution suit.
}

${ }^{14}$ E.g., Rivera v. Hopatcong Borough Police Dep't, No. 08-2721, 2010 WL 446040 (D.N.J. Feb. 3, 2010); Vaughan v. Ky. Army Nat'l Guard, No. 3:15-6-GFVT, 2016 U.S. Dist. LEXIS 53389 (E.D. Ky. Apr. 21, 2016) (and the many related cases, including Vaughan v. United States, No. 3:10-54-DCR (E.D. Ky. 2010) (resulting in the ruling 2012 WL 6048699 on Dec. 5, 2012); Vaughan v. Ky. Army Nat'l Guard, No. 3:12-34-DCR (E.D. Ky. 2012); Vaughan v. Ky. Army Nat'l Guard, No. 3:12-35-DCR (E.D. Ky. May 2, 2012); Vaughan v. Ky. Army Nat'l Guard, No. 3:12-53-DCR (E.D. Ky. 2012)).

15 Telish v. State Pers. Bd., 184 Cal. Rptr. 3d 873 (Cal. Ct. App. 2015). 
- an employee's lawsuit against an employer because coworkers had engaged in nonconsensual pornography dissemination. ${ }^{16}$

○ attorney discipline for disseminating nonconsensual pornography. ${ }^{17}$

o insurance coverage disputes for civil lawsuits involving nonconsensual pornography dissemination. ${ }^{18}$

How We Counted Actions. We compiled eighty-nine enforcement actions involving nonconsensual pornography dissemination. The compilation includes actions that never produced any substantive court opinion if we could find an original source material, such as a complaint. Actions that produced more than one court opinion were counted as a single action.

In some situations, we combined multiple lawsuits by the same plaintiffs into a single action. For example, the Tommy and Pamela Anderson Lee sex tapes resulted in lawsuits against several different defendants, but we counted all the lawsuits as a single enforcement action. Similarly, an enforcement action with the same plaintiff(s) and multiple defendants was counted as a single action. However, we counted parallel civil and criminal enforcements against the same defendant (e.g., Bollaert) as separate actions.

Compilation Methodology. We generated the compilation through numerous keyword searches in Westlaw and Lexis. ${ }^{19}$ We

\footnotetext{
${ }^{16}$ McCormick v. Donovan, 365 F. App’x 247 (2d Cir. 2010).

${ }_{17}$ People v. Saxon, No. 16PDJo18, 2016 WL 8540133 (Colo. O.P.D.J. Nov. 7, 2016); see also Keaton.

${ }^{18}$ See, e.g., Liberty Insurance Corp. v Anderson, No. 1:16CV2249, 2017 WL 2962333 (N.D. Ohio July 12, 2017). Note that this ruling is also outside of the compilation's time scope.

19 Our search queries included (among others) "revenge porn," "sexual or explicit and photos and 'posted online' and relationship," "sexual or explicit and photos and online and relationship," "sexual or explicit and photos and online," "revenge w/1 porn!"

"nonconsensual porn!," "nonconsensual porn! and not "child porn!," "explicit images and nonconsensual or 'without permission' and not child porn!," "involuntary porn!," "involuntary porn! and not child! porn!," and "relationship and send or sent w/2 nude or explicit w/1 photo! or image! or video! and not child porn!" "explicit w/2 image! or photo! or video! and relationship or intimate and not child!" Except where noted, we ran all queries in both Westlaw and Lexis.
}

We also reviewed case citations for the following statutes (except where nonconsensual pornography references were too commingled with a large number of other references): Alaska Stat. § 11.61.120; Ariz. Rev. Stat., § 13-1425; Ark. Code § 5-26-314; Cal. Penal Code § 647(j)(4); Colo. Rev. Stat. § 18-7-107; Conn. Gen. Stat. § 53a-189c; 11 Del. C. § 1335; Fla. 
supplemented this with cases we found ad hoc while doing other research, as well as by following up on news reports. We set a compilation cutoff date of December 31, 2016, but some keyword searches were conducted before then.

Electronic Database Limitations. Keyword searches in Westlaw and Lexis are subject to numerous limitations. First, the nomenclature confusion hinders the efficacy of keyword searches. Opinions rarely use terms like "revenge porn" or "nonconsensual pornography," so we tried an array of keyword searches. Despite our multitudinous efforts, our keyword searches surely did not identify all of the relevant cases in Westlaw or Lexis.

Furthermore, many case materials never make it into the Westlaw or Lexis databases. Each database includes court opinions selectively, and their coverage of state court proceedings is particularly spotty (more on that in a moment). Older opinions never may have been digitized (we also encountered this problem with PACER). Also, compared to other types of cases, nonconsensual pornography cases have a greater likelihood of being partially or fully sealed. ${ }^{20}$

We used PACER to supplement our research into federal court proceedings. However, PACER's "nature of suit" code, which categorizes cases based on the plaintiff's substantive claims, ${ }^{21}$ does not help because nonconsensual pornography dissemination cuts across a wide variety of claims.

Limited Visibility on State Court Proceedings. The electronic databases prioritize appellate rulings and federal district court opinions for inclusion, which leaves state court proceedings underrepresented in their databases. Most state courts do not have an electronic repository of case materials analogous to PACER, so their

Stat. § 784.049; O.C.G.A. § 16-11-90; Haw. Rev. Stat. § 711-1110.9; Idaho Code Ann. § 186609; 750720 Ill. Comp. Stat. Ann. 5/11-23.5; Kan. Stat. § 21-6101(a)(8); La. R.S. 14:283.2; 17-AM.R.S. § 511-A; Md. Code Ann., Crim. Law § 3-809; MCLS § 750.145e; Minn. Stat. § 617.261; Nev. Rev. Stat. Ann. § 200.604; N.H. Rev. Stat. § 644:9-a; N.J. Stat. § 2C:14-9; N.M. Stat. Ann. § 30-37A-1; N.C. Gen. Stat. § 14-190.5A; N.D. Cent. Code, § 12.117-07.2; 21 Okla. St. § 1040.13b; ORS § 163.472; 18 Pa. C.S. § 3131; Tenn. Code Ann. § 3917-318; Tex. Penal Code § 21.16; Utah Code § 76-5b-203; 13 V.S.A. § 2606; Va. Code Ann. § 18.2-386.2; Rev. Code Wash. (ARCW) § 9A.86.010; Rev. Code Wash. (ARCW) § 4.24.795; Wis. Stat. § 942.09.

${ }^{20}$ For example, Christman Hubbard proceeded under seal initially. The filings were not made public for several years after the judge's issuance of a permanent injunction.

${ }^{21}$ Nature of Suit Codes, PACER, https://www.pacer.gov/documents/natsuit.pdf [https://perma.cc/B6T6-UWBJ]. 
proceedings are not easily searchable and their filings are not easily retrievable. This makes state court nonconsensual pornography enforcement actions difficult or impossible to compile. In turn, the non-searchability and inaccessibility of state court records obscure a significant part of the total universe because state law and common law doctrines play important roles in the enforcement actions.

In particular, it is not possible to systematically find or track enforcements of the state sui generis laws. For example, as discussed in Part III(D) infra, we found news reports of fourteen sui generis prosecutions in Hawaii and Minnesota. However, we could not find the associated source materials, so none of those actions are included in the compilation. Assuming other states with sui generis laws are experiencing similar enforcement volumes, our compilation is likely missing hundreds of such enforcement actions.

Enforcement Actions Never Brought. The vast majority of nonconsensual pornography disseminations do not result in enforcement actions, and any compilation of enforcement actions necessarily has selection biases towards the attributes that cause plaintiffs to bring cases.

There are many good reasons why enforcement actions are not brought. On the civil side, ${ }^{22}$ victims may not be able to afford to litigate (because they cannot pay the legal fees, the defendants are judgment-proof, or both); it can be difficult to find a competent lawyer; victims may fear further victimization from participating in the litigation, including the Streisand Effect (the unwanted consequence of drawing further attention to private material by trying to suppress the material); ${ }^{23}$ or victims may determine for a wide range of reasons that a successful lawsuit will not be worth it.

On the criminal side, law enforcement and prosecutors may not pursue cases for a variety of reasons, including: they may not take violations seriously enough; they may face challenges securing

\footnotetext{
22 See Danielle K. Citron \& Mary Anne Franks, Criminalizing Revenge Porn, 49 WAKE FOREST L. REV. 345, 358 (2014); Susana Lichter, Unwanted Exposure: Civil and Criminal Liability for Revenge Porn Hosts and Posters, HARV. J. L. \& TECH. JOLT DIGEST (May 27, 2013), http://jolt.law.harvard.edu/digest/unwanted-exposure-civil-and-criminal-liabilityfor-revenge-porn-hosts-and-posters [https://perma.cc/32W7-J6FY]; Jessica Meiselman,'Our Society's Deep Sexual Dysfunction': Why It's So Hard to Stop Revenge Porn, VICE (Mar. 17, 2017), https://broadly.vice.com/en_us/article/our-societys-deepsexual-dysfunction-why-its-so-hard-to-stop-revenge-porn [https://perma.cc/3U44-R24L].
}

${ }^{23}$ See, e.g., Justin Parkinson, The Perils of the Streisand Effect, BBC (July 31, 2014), http://www.bbc.com/news/magazine-28562156 [https://perma.cc/5DHU-A9ZG]. 
credible evidence or witnesses; they may feel stymied by the need to fit the prosecution into antiquated or ill-fitting criminal laws; or they may face jurisdictional issues. ${ }^{24}$ We found several news reports of terminated nonconsensual pornography dissemination investigations, ${ }^{25}$ but we generally excluded these incidents because we lacked original source materials and could not confidently assess why the investigation stopped (public statements may not reflect the actual story).

What Can We Learn from the Observable Universe? If we had a truly comprehensive compilation, or if we thought our compilation reflected the actual universe without any distortions, we could use the total number of compiled action as a denominator to generate percentage-based statistics about the compilation, such as the percentage of compiled cases that resulted in a plaintiff win. While we do not know any reason why the compilation skews plaintiff- or defense-favorable, we are also not confident that the compilation proportionately reflects the actual enforcement universe. Therefore, we have chosen to present only absolute, not relative, statistics. We nevertheless think absolute statistics can provide substantial insights. The compilation also provides a helpful complement to individual anecdotes by illustrating repeating pathologies and patterns.

\section{THE COMPILATION TAXONOMY}

\footnotetext{
24 Factors that inhibit enforcement may be partially ameliorated, but are not eliminated, by the sui generis laws. See, e.g., Avlana K. Eisenberg, Criminal Infliction of Emotional Distress, 113 MICH. L. REv. 607, 653 (2015) (criticizing California's sui generis law for being too hard for prosecutors to enforce).

${ }^{25}$ See, e.g., Stacy St. Clair, Accuser 'Devastated' After Blackhawks Quickly Reinstate Prospect in Revenge Porn Case, CHI. TRIB., Mar. 30, 2016, http://www.chicagotribune.com/sports/hockey/blackhawks/ct-revenge-porn-accusergarret-ross-0331-20160330-story.html [https://perma.cc/TSP5-VGFH] (prosecutors dropping a case involving a hockey player's disclosure of an explicit video to a teammate, purportedly for jurisdictional reasons); Michael E. Miller, Revenge Porn Victim Holly Jacobs "Ruined My Life," Ex Says, Miami NeW Times (Oct. 17, 2013), http://www.miaminewtimes.com/news/revenge-porn-victim-holly-jacobs-ruined-my-lifeex-says-6393654 [https://perma.cc/WR6P-UAH4] (prosecutors dropping a prosecution against ex-boyfriend Ryan Seay for lack of evidence that he had disseminated the photos or created a fake email account); $c f$. Olsen v. Henderson, No. 2:12-CV-543 JCM (PAL) (D. Nev. Feb. 27, 2014), https://www.leagle.com/decision/infdco20140228f16 [https://perma.cc/26KW-QQ2H] (prosecutors declining to prosecute a student who borrowed a classmate's cellphone and used it to email nude photos from the cellphone to himself).
} 
We taxonomized the enforcement actions into four categories: offline dissemination, online dissemination, threatened dissemination, and actions against intermediaries. ${ }^{26}$

Offline Dissemination. Nonconsensual pornography is typically associated with Internet dissemination, but dissemination can take place offline as well. Indeed, enforcement actions against offline disseminations date back to the 1980s. Appendix A summarizes the six cases we found involving offline dissemination.

Online Dissemination. ${ }^{27}$ Many online dissemination cases are what most readers would colloquially refer to as "revenge porn." Indeed, we found numerous cases where an ex-romantic partner disseminates photos or videos over the Internet to harm the victim. Appendix B summarizes the thirty-nine cases we found involving online dissemination.

Threatened Disseminations. Threatened disseminations generally look similar to the offline and online dissemination cases-except that because dissemination has not yet taken place, a successful enforcement action can prevent the dissemination from ever occurring. At least twenty-one of these cases involve behavior that might be characterized as "sextortion," 28 including:

- Seven involving extortion for money.

- Six involving extortion for additional photos/videos.

- Six involving extortion for sexual favors.

Appendix C summarizes the thirty-one cases we found involving threatened dissemination. ${ }^{29}$

Actions Against Intermediaries. The first three taxonomy categories are based on the dissemination method. In contrast, the final taxonomy category is based on the defendant's status as an intermediary. An intermediary does not make the initial decision to

\footnotetext{
${ }^{26}$ Each appendix lists the actions roughly chronologically. Many cases had additional extenuating circumstances involving the parties that we omitted to focus the narrative tightly on just dissemination.

${ }_{27}$ We excluded State v. Zimmerman, 314 P.3d 850, 2013 WL 6507550 (Haw. Ct. App. Dec. 11,2013 ), because it was impossible to isolate the role that nonconsensual pornography played in the sentencing given the multiple other crimes involved in the case.

${ }^{28}$ What is Sextortion?, Federal Bureau of Investigation, https://www.fbi.gov/videorepository/newss-what-is-sextortion/view [https://perma.cc/3H4W-SCVW].
}

29 We excluded Walls v. Klein, No. 04-12-00615-CV, (Tex. App. Ct. Mar. 13, 2013), because we could not verify that the photos at issue were pornographic. 
disseminate nonconsensual pornography, but its publication tools can increase the dissemination's reach.

We felt that intermediary cases should be separated from the other cases for several reasons. First, intermediaries are often more compelling defendants than their uploaders. $3^{\circ}$ The actual disseminator may be anonymous or pseudonymous, while an intermediary may be easier to find. The intermediary also may have deeper pockets. ${ }^{31}$

Second, intermediaries can cut off further dissemination on its network..$^{2}$ Often, victims eagerly want to stop further dissemination, and intermediaries can provide that remedy with-or withoutjudicial proceedings. Indeed, several major online services have voluntarily adopted policies to remove nonconsensual pornography. ${ }^{33}$

Third, intermediaries are usually commercial enterprises, such as "revenge porn websites" that charge victims to remove the postings from their databases. Compared to an individual disseminator, the intermediaries' commerciality increases the number of potential claims and affects how the claim elements might be interpreted.

Finally, intermediaries may qualify for the immunity from liability provided by 47 U.S.C. $§ 230$ ("Section 230"), the law that Congress enacted in 1996 to absolve online publishers from liability for usersupplied materials. Section 230 plays an important role in enforcement actions against intermediaries, though it has not been insurmountable.

\footnotetext{
${ }^{30}$ See Mary Anne Franks, Sexual Harassment 2.o, 71 MD. L. REv. 655 (2009).

${ }^{31}$ See id. at 693-694; Lichter, supra note 22.

${ }^{32}$ See Lilian Edwards, Revenge Porn: Why The Right To Be Forgotten Is The Right Remedy, THE GUARDIAN (July 28, 2014),

https://www.theguardian.com/technology/2014/jul/29/revenge-porn-right-to-beforgotten-house-of-lords [https://perma.cc/JV6K-95NU] ("[W] hat victims of revenge porn really want most urgently is a remedy, not a prosecution").
}

33 See, e.g., Megan Geuss, Twitter Will Ban Revenge Porn And Non-Consensual Nudes, ARS TECHNICA (Mar. 12, 2015), https://arstechnica.com/tech-policy/2015/o3/twitter-willban-revenge-porn-and-nonconsensual-nudes/ [https://perma.cc/6FDF-KS4E]; Kashmir Hill, Google Will Let You Remove Nude Images of Yourself From Search, Fusion (June 19, 2015), http://fusion.net/story/15390o/google-bans-revenge-porn-too/ [https://perma.cc/R8J8-3AVJ]; Antigone Davis, Using Technology to Protect Intimate Images and Help Build a Safe Community, FACEBOOK NEWSROOM (Apr. 5, 2017), https://newsroom.fb.com/news/2017/04/using-technology-to-protect-intimate-imagesand-help-build-a-safe-community/ [https://perma.cc/8TUK-22JK]. 
Appendix D summarizes the thirteen cases we found against online intermediaries. 34

\section{ANALYSIS OF THE COMPILATION}

\section{A. Demographics}

Venerability of the Issues. Nonconsensual pornography dissemination is often viewed as a recent phenomenon associated with the Internet's growth. 35 No doubt, the Internet increases the number and perniciousness of such disseminations. ${ }^{36}$ However, the phenomenon is not "new." The earliest case in our compilation is from 1984. This histogram approximately 37 illustrates the dates for compiled cases:

\footnotetext{
34 We decided to include the Hudson actions in the offline dissemination category rather than here, even though the plaintiffs sued an offline magazine for publishing the images.

35 See Jack Simpson, Revenge Porn: What Is It and How Widespread Is The Problem?, INDEPENDENT (July 2, 2014), http://www.independent.co.uk/news/uk/home-news/whatis-revenge-porn-9580251.html [https://perma.cc/6NMD-E8NK].

${ }^{36} I d$.

37 We generally assigned a case's date by what we considered the most important court ruling in the case. Where the case did not produce a key ruling, we usually dated the case by its complaint. Recall the discussion in Part I about our challenges researching older cases.
} 


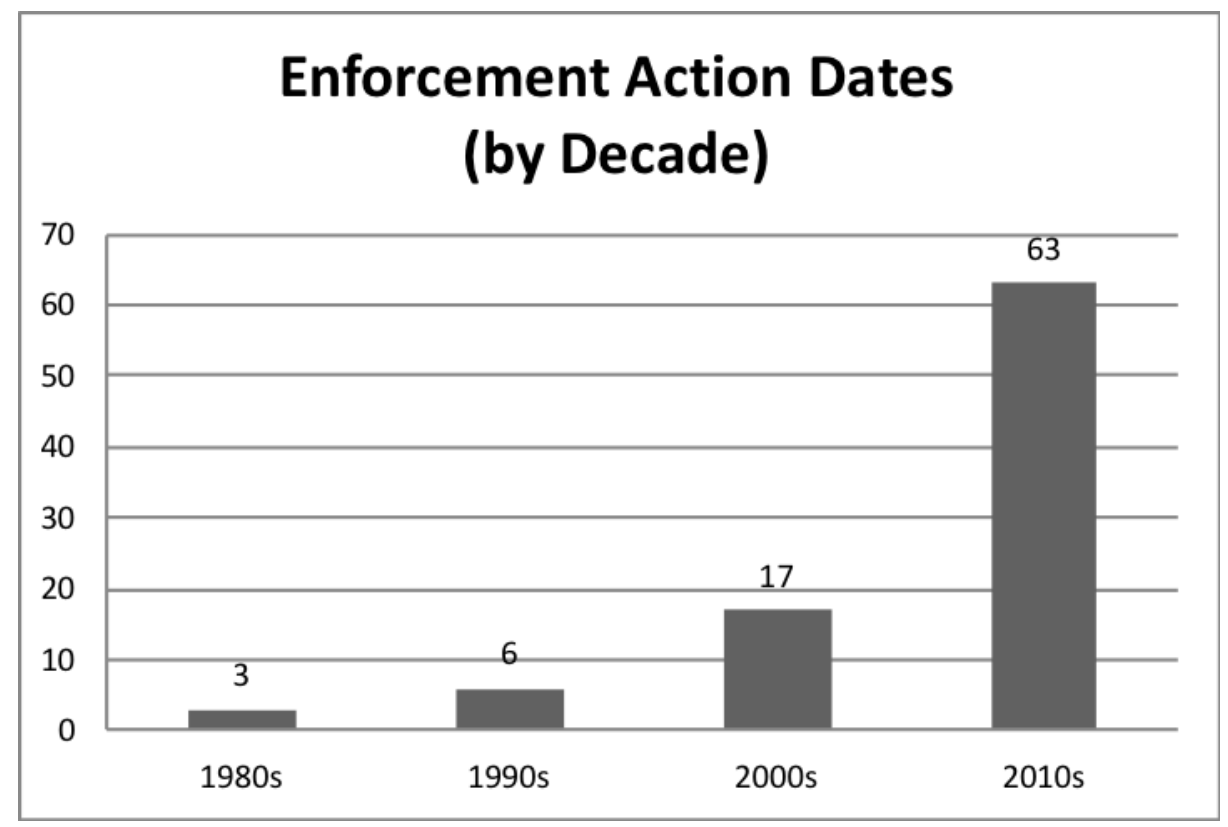

Male Victims. Consistent with the stereotypes, most of our compiled cases involve male defendants and female victims. However, men are often overshadowed as victims. Men are-and will remainan important minority segment of the victim community. In at least seven cases in our compilation, $3^{8}$ men were victims of nonconsensual pornography dissemination.

\footnotetext{
${ }^{8}$ See Farrell v. Narain, No. 2:05-cv-07244 (C.D. Cal. Oct 5, 2005); Farrell v. Narain, No. 2:05-cv-05668 (C.D. Cal. Aug. 3, 2005); Farrell v. Narain, No. BC336690, 2005 WL 6522674 (Cal. Super. Ct. 2005); Colin Farrell Sues Over Sex Tape, THE SMOKING GuN (July 19, 2005), http://www.thesmokinggun.com/documents/crime/colin-farrell-suesover-sex-tape [https://perma.cc/78VW-KAYF]; Jersevic v. Kuhl, No. oo-CV-10113-BC, 2000 U.S. Dist. LEXIS 21760 (E.D. Mich. Mar. 29Sept. 22, 2000); Jersevic v. Kuhl, No. 238808, 2003 WL 1558207 (Mich. Ct. App. Mar. 25, 2003); United States v. Esler, 531 F. App’x 502 (5th Cir. 2013); Tharpe v. Lawidjaja, 8 F.Supp. 3d 743 (W.D. Va. 2014); Rogers v. Brindle, 12-1-08807-53 (Ga. Superior Ct.); Caraccioli v. Facebook, Inc., 167 F.Supp.3d 1056 (N.D. Cal. 2016); Caraccioli v. Facebook, Inc., 2017 U.S. App. LEXIS 10040 (9th Cir. June 6, 2017); State v. Ravi, 147 A.3d 455 (N.J. App. Div. 2016); see also supra note 29 (the Walls case); Woman, 32, Arrested For Distributing Naked Photos Of Her ExHusband, THE SMOKING GUN (Nov. 22, 2016), http://www.thesmokinggun.com/buster/florida/hide-that-flash-drive-guys-017348 [https://perma.cc/L947-S3RL] (arrest of Eva Gaitan); Doe v. Ruiz, BC 640012 (Cal. Super. Ct. filed Nov. 8, 2016), https://localtvkdvr.files.wordpress.com/2016/11/von-millerlawsuit.pdf [https://perma.cc/X87S-7MJP].
} 
Celebrity Victims. Celebrity cases play a conspicuous role in the compilation. 39 Celebrity-related material can have high financial value if commercialized or used for extortion, 40 and celebrities may experience the Streisand Effect if they bring enforcement actions. This makes celebrities especially vulnerable to stolen pornography. Furthermore, celebrities often have the financial ability to obtain legal representation to bring enforcement actions while most victims cannot afford to do so.

Parallel Civil/Criminal Enforcement. At least five incidents involved both civil and criminal enforcement ${ }^{41}$ (because we counted

\footnotetext{
39 See e.g., Farrell v. Narain, No. 2:05-cv-07244 (C.D. Cal. Oct 5, 2005); Farrell v. Narain, No. 2:05-cv-05668 (C.D. Cal. Aug. 3, 2005); Farrell v. Narain, No. BC336690, 2005 WL 6522674 (Cal. Super. Ct. 2005); Colin Farrell Sues Over Sex Tape, THE SMOKING GuN (July 19, 2005), http://www.thesmokinggun.com/documents/crime/colin-farrell-suesover-sex-tape [https://perma.cc/78VW-KAYF]; Miranda v. Guerrero, 2009 WL 1381250 (S.D. Fla. May 14, 2009); Leviston v. Jackson, 980 N.Y.S.2d 716 (Sup. Ct. 2013); Bollea v. Gawker Media, LLC, 913 F. Supp. 2d 1325 (M.D. Fla. 2012), Lee v. Penthouse Int'l, 1997 WL33384309 (C.D. Cal. Mar. 19, 1997) (order granting summary judgment) (Tommy Lee and Pamela Andersen case); see also Ritchie et al v. World Wide Red Light District et al, 2006 WL 678840 (E.D. Mich. filed Feb. 21, 2006); Stapp v. Worldwide Red Light District, Docket No. 2:06-cv-01570 (C.D. Cal. filed Mar. 14, 2006); Doe v. World Wide Red Light District, No. 2006-004056-CA-01 (Fla. Cir. Ct. filed Mar. 2, 2006) (the Scott Stapp/Kid Rock cases). There also have been the wide-scale releases of stolen celebrity photos, such as the "Fappening" and the "Snappening."
}

${ }^{40}$ Celebrities and other wealthy individuals are especially vulnerable to the nonconsensual recording of sexual activity followed by an extortionate demand to keep the recording private. See, e.g., Doe v. Ruiz, BC 640012 (Cal. Super. Ct. filed Nov. 8, 2016), https://localtvkdvr.files.wordpress.com/2016/11/von-miller-lawsuit.pdf [https://perma.cc/X87S-7MJP]; Hubbard v. Azzara, No. 8:01-cv-1154-T-24 EAJ, 2008 WL 2782828 (M.D. Fla., July 16, 2008), Rogers v. Brindle, 12-1-08807-53 (Ga. Superior Ct.); United States v. Tarlow, No. 3:15-cr-00239 (N.D. Cal. filed Apr. 30, 2015).

${ }^{41}$ Azzara, Bollaert, Elam, Kuhl, and Roebuck. Hubbard v. Azzara, No. 8:01-cv-1154-T-24 EAJ, 2008 WL 2782828 (M.D. Fla. July 16, 2008); United States v. Azzara, No. 02-1739, 2003 WL 193738 (2d Cir. Jan. 29, 2003), United States v. Azzara, No. 04-0809-CR, 2005 WL 1331273 (2d Cir. June 6, 2005), Azzara v. United States, 2011 U.S. Dist. LEXIS 122689 (S.D.N.Y. Oct. 20, 2011); People v. Bollaert, 248 Cal. App. 4th 699 (2016); Complaint, Doe v. Bollaert, No. 2:13CV-486 (S.D. Ohio May 21, 2013), http://www.plainsite.org/dockets/download.html?id=3231146o\&z=ddo41fge; Order, Doe v. Bollaert, No. 2:13-CV-486 (S.D. Ohio Mar. 18, 2014),

http://www.plainsite.org/dockets/download.html?id=167384616\&z=ofib373e; U.S. v. Elam, Docket No. 2:14-cr-00368 (C.D. Cal. Jun 24, 2014); Complaint, Doe v. Elam, 2:14-cv-09788PSG-MAN (C.D. Cal. Dec. 24, 2014); People v. Kuhl, No. 203979, 1999 Mich. App. LEXIS 2257 (Mich. Ct. App. Dec. 28, 1999); Jersevic v. Kuhl, NoCASE NO. oo-CV-10113-BC, 2000 U.S. Dist. LEXIS 21760 (E.D. Mich. Sept. 22, 2000); Jersevic v. Kuhl, No. 238808, 2003 WL 1558207 (Mich. Ct. App. Mar. 25, 2003); Docket, Roebuck v. Scott, No. 2012-006627 (Pa. Ct. Com. Pl. complaint filed Aug. 2, 2012), 
each action separately, these incidents comprised ten of the eightynine compiled actions). It's likely that other cases in the compilation had parallel enforcement actions that we did not identify.

The parallel enforcements prompt some questions, such as: Why did these cases, and not others, have parallel actions? In terms of providing justice for victims, were the parallel actions additive or duplicative? If the civil and criminal cases reached different conclusions, what was the reason?

The parallel civil/criminal enforcement cases would benefit from closer study. They may be able to provide greater insights into the relative pros and cons of civil and criminal actions as ways to remediate nonconsensual pornography dissemination violations.

\section{B. Claims Analysis}

Diversity of Legal Claims. As the compilation's taxonomy illustrates, the dissemination of "nonconsensual pornography" involves heterogeneous activities. Not surprisingly, a large number of different laws were litigated in compiled cases. By our count, plaintiffs have succeeded with no less than twenty-six different legal doctrines at least once..$^{2} \mathrm{~A}$ breakdown of the successful legal theories, ordered by the frequency of their success (as far as we could determine):

\begin{tabular}{|l|l|l|}
\hline \multicolumn{1}{|c|}{ Doctrine } & \multicolumn{1}{|c|}{$\begin{array}{c}\text { Cases Where It } \\
\text { Succeeded }\end{array}$} & \multicolumn{1}{c|}{ Comments } \\
\hline $\begin{array}{l}\text { "Invasion of Privacy" (11 } \\
\text { times) }\end{array}$ & $\begin{array}{l}\text { Bollea, Bruce, } \\
\text { Christman Hubbard, } \\
\text { Del Mastro, } \\
\text { Hoewischer, Hudson, } \\
\text { Kid Rock, Leviston, } \\
\text { Patel, Peterson, Rogers }\end{array}$ & $\begin{array}{l}\text { It was not always clear } \\
\text { what courts meant by } \\
\text { "invasion of privacy." } \\
\text { At least two of the } \\
\text { cases (Patel and } \\
\text { Bollea) involve } \\
\text { intrusion into seclusion }\end{array}$ \\
\hline
\end{tabular}

http://roam.co.delaware.pa.us/delco/search.do?indexName=docketcase\&templateName=case \&lq=CASE_NUMBER\%3A\%222012-006627\%22 [https://perma.cc/CVZ5-99QT].

${ }^{42}$ It might be interesting to compile the causes of action that have been litigated but never successfully. However, we couldn't comprehensively compile the asserted causes of action or accurately determine if those claims pertained to nonconsensual pornography dissemination or other facts. 


\begin{tabular}{|c|c|c|}
\hline Doctrine & $\begin{array}{l}\text { Cases Where It } \\
\text { Succeeded }\end{array}$ & Comments \\
\hline $\begin{array}{l}\text { Child pornography or } \\
\text { child sex exploitation (10 } \\
\text { times) } 43\end{array}$ & $\begin{array}{l}\text { Beckett, Bollaert (the } \\
\text { civil case), Browne, } \\
\text { Esler, Hutchinson, } \\
\text { J.O., Kisling, } \\
\text { Schnitker, Shea, Talley }\end{array}$ & $\begin{array}{l}\text { For simplicity, we } \\
\text { combined torts and } \\
\text { crimes into a single } \\
\text { category }\end{array}$ \\
\hline $\begin{array}{l}\text { Intentional infliction of } \\
\text { emotional distress } \\
\text { (IIED) ( } 9 \text { times) }\end{array}$ & $\begin{array}{l}\text { Bollea, Del Mastro, } \\
\text { Hofstetter, Leviston, } \\
\text { Patel, Peterson, } \\
\text { Prezioso, Taylor, } \\
\text { Thomas }\end{array}$ & $\begin{array}{l}\text { Taylor also succeeded } \\
\text { with negligent infliction } \\
\text { of emotional distress } \\
\text { (NIED). Patel did not } \\
\text { get any damages for her } \\
\text { IIED claim }\end{array}$ \\
\hline Extortion (8 times) & $\begin{array}{l}\text { Azzara, Bollaert (the } \\
\text { criminal case), Hutson, } \\
\text { Kuhl, Meyering, } \\
\text { Pauling, Petrovic, } \\
\text { Vafaie }\end{array}$ & \\
\hline $\begin{array}{l}\text { Stalking/Cyberstalking } \\
\text { (8 times) }\end{array}$ & $\begin{array}{l}\text { Ackell, Brown, } \\
\text { Cavazos, D.C., } \\
\text { Franklin, Osinger, } \\
\text { Petrovic, Sayer }\end{array}$ & \\
\hline $\begin{array}{l}\text { Public Disclosure of } \\
\text { Private Facts ( } 7 \text { times) }\end{array}$ & $\begin{array}{l}\text { Backlund, Bollea, } \\
\text { Bruce, Hofstetter, } \\
\text { Patel, Peterson, Taylor }\end{array}$ & \\
\hline Identity Theft ( 5 times) & $\begin{array}{l}\text { Bollaert, Kisling, } \\
\text { Ledgard, Moore, Sayer }\end{array}$ & \\
\hline $\begin{array}{l}\text { Sui generis anti- } \\
\text { nonconsensual } \\
\text { pornography laws ( } 5 \\
\text { times) }\end{array}$ & $\begin{array}{l}\text { Barber, McLellan, } \\
\text { Morehead, Parsons, } \\
\text { Yarber }\end{array}$ & $\begin{array}{l}\text { As discussed, many } \\
\text { enforcements of the sui } \\
\text { generis laws are } \\
\text { outside the observable } \\
\text { universe }\end{array}$ \\
\hline Harassment (4 times) & $\begin{array}{l}\text { D.C., Kochanowski, } \\
\text { Roebuck, Vafaie }\end{array}$ & \\
\hline $\begin{array}{l}\text { Criminal Threat ( } 3 \\
\text { times) }\end{array}$ & $\begin{array}{l}\text { Azzara, Tarlow, } \\
\text { Ybarra }\end{array}$ & \\
\hline $\begin{array}{l}\text { Assault/Battery (3 } \\
\text { times) }\end{array}$ & $\begin{array}{l}\text { Cavazos, Stancl, } \\
\text { Vafaie }\end{array}$ & \\
\hline Publicity rights (3 times) & $\begin{array}{l}\text { Bollaert (the civil } \\
\text { case), Bollea, Talley }\end{array}$ & \\
\hline Obscenity (2 times) & Hutchinson, Roebuck & \\
\hline
\end{tabular}

43 As we mentioned, we generally excluded child pornography cases, so this category reflects the cases we felt were within the compilation's scope. 


\begin{tabular}{|l|l|l|}
\hline \multicolumn{1}{|c|}{ Doctrine } & \multicolumn{1}{|c|}{$\begin{array}{c}\text { Cases Where It } \\
\text { Succeeded }\end{array}$} & \multicolumn{1}{c|}{ Comments } \\
\hline $\begin{array}{l}\text { Computer Fraud \& } \\
\text { Abuse Act (2 times) }\end{array}$ & Ledgard, Moore & Kid Rock, Miranda \\
\hline Lanham Act (2 times) & $\begin{array}{l}\text { Miranda involved a } \\
\text { false designation of } \\
\text { origin. Kid Rock } \\
\text { involved trademark } \\
\text { infringement. }\end{array}$ \\
\hline Negligence (2 times) & Bruce, Vafaie & \\
\hline $\begin{array}{l}\text { Defamation/False Light } \\
\text { (2 times) }\end{array}$ & Backlund, Taylor & \\
\hline $\begin{array}{l}\text { Rape/Attempted Rape } \\
\text { (2 times) }\end{array}$ & Piznarski, Serrano & \\
\hline
\end{tabular}

We also found one successful assertion of each of the following claims: compelled prostitution (Dula), conspiracy (Wood), deterring a witness (Wood), witness retaliation (Kushner), Florida's "Security of Communications Act" (Bollea), fraudulent use of personally identifiable information (Roller), unlawful imprisonment (Piznarski), and unlawful surveillance (Piznarski).

Prosser's four common law privacy torts44-public disclosure of private facts, intrusion into seclusion, false light and publicity rightsplay a significant role in the successful enforcement actions. This makes some sense because common law doctrines naturally allow judges to apply them to new facts as justice requires. Thus, the Prosser privacy torts can cover novel anti-social behavior such as nonconsensual pornography dissemination.

Also, IIED cases are typically considered difficult for plaintiffs to win. ${ }^{45}$ Over the years, courts have been increasingly exacting about the requirements for a successful claim. Yet, nonconsensual pornography dissemination plaintiffs have had some success with IIED. In light of our compilation's scope, this makes sense because disseminators often seek to inflict emotional distress by disseminating

44 William L. Prosser, Privacy, 48 CAL. L. REV. 383 (1960).

45 See, e.g., Andrew Meerkins, Distressing Speech After Snyder - What's Left of IIED?, 107 NW. U. L. REv. 999 (2013); Sara Ruliffson, R.I.P. I.I.E.D.: The Supreme Court of Texas Severely Limits The Tort of Intentional Infliction of Emotional Distress, 58 BAYLOR L. REV. 587 (2006); Russell Fraker, Reformulating Outrage: A Critical Analysis of the Problematic Tort of IIED, 61 VAND. L. REV. 983 (2008) ("Despite this general acceptance of the tort, courts routinely assert that IIED is a disfavored cause of action.”). 
"revenge" pornography.46 Indeed, nonconsensual pornography dissemination seems to be a paradigmatic example of IIED.

In contrast, copyright plays less of a role in the compilation than we might have expected. Every photo and video at issue in every compiled case is likely owned by someone under copyright law. While the victims won't necessarily own those copyrights, many of the compiled cases involved situations where the victims seemed likely to own the copyrights. Furthermore, Section 230 does not immunize copyright claims, ${ }^{47}$ making it more fruitful to bring copyright claims against intermediaries than many other types of claims.

Yet, none of the compiled cases involved the victim winning a copyright claim. We can hypothesize with some possible selection biases that might explain a reduced role for copyright litigation, ${ }^{48}$ such as the likelihood that copyright takedown notices helped victims remove photos or videos without going to court, the possibility that the Digital Millennium Copyright Act's safe harbors49 reduced the exposure of intermediaries, and the likelihood that the victims were not eligible for statutory damages $5^{\circ}$ and actual damages were not worth pursuing. Nevertheless, it seems unlikely that nonconsensual pornography dissemination victims have never succeeded on copyright claims, so the paucity of copyright successes may reflect limitations in the compilation methodology.

The Role of Section 230. Section 230 has been heavily criticized for its alleged role in enabling nonconsensual pornography

\footnotetext{
46 RESTATEMENT (SECOND) OF TORTS $§ 46$ (1965) (defining liability under IIED to anyone "who by extreme and outrageous conduct intentionally or recklessly causes severe emotional distress); Citron \& Franks, supra note 22, at 350-354 (explaining how revenge porn increases the risks of offline stalking and physical attack, anxiety, panic attacks, Anorexia nervosa, depression, inability to find work, and humiliation).

4747 U.S.C. § 230(e)(2) (2012).

${ }^{48}$ Cf. Rebecca Tushnet, How Many Wrongs Make a Copyright?, 98 MINN. L. ReV. 2346 (2014) (discussing some conceptual problems with over-expansive applications of copyright law to nonconsensual pornography).

4917 U.S.C. $\S 512$ (2012).

${ }^{50}$ Eligibility for statutory damages requires timely registrations. 17 U.S.C. § 504(c) (2012). Most non-professional photographers/videographers do not regularly register copyrights in their works, and copyright registration requires submitting the work to a government agency (the Copyright Office), which conflicts with the victims' desire to keep the work private.
} 
dissemination. 51 $^{1}$ These concerns have some foundation. Unquestionably, Section 230 is a powerful immunity for intermediaries, and has supported defense wins in two cases (GoDaddy and Caraccioli).

However, Section 230 does not always produce a defense win. For example, in Barnes, Section 230 eliminated some of the victim's claims but not all of them. In Bollaert (the criminal prosecution), the prosecution overcame a vigorous Section 230 defense. In other cases, such as the Meyering and Moore cases, Section 230 did not appear to be a factor at all.

Also, some cases did not involve any targetable online intermediary, such as offline disseminations and disseminations by email. In cases without a targetable immunity, Section 230's immunity was irrelevant.

Furthermore, as noted above, several major intermediaries have adopted "house rules" against nonconsensual pornography dissemination, even in circumstances where Section 230 immunizes them from liability.

These and other considerations raise the possibility that Section 230 's role in nonconsensual pornography dissemination may not merit the substantial ire directed towards it. Furthermore, Section 230's immunity plays an important role in a wide range of online content, of which nonconsensual pornography is just one of many content categories. Any Section 230 reform may not materially improve the nonconsensual pornography dissemination issues and could substantially harm other essential aspects of the Internet. ${ }^{2}$

\footnotetext{
${ }^{51}$ Hundreds of articles have advanced this argument. For a small sampling, see for example, Lichter, supra note 22; Casey Martinez, An Argument For States To Outlaw 'Revenge Porn' And For Congress To Amend 47 U.S.C. \$ 230: How Our Current Laws Do Little To Protect Victims, 14 U. PITT. J. TECH. L. \& POL'Y 236 (2014); Allison Tungate, Bare Necessities: The Argument for a 'Revenge Porn' Exception in Section 230 Immunity, 23 INFO. \& COMMC'N TECH. L. 172, http://www.tandfonline.com/doi/full/10.1080/13600834.2014.916936.
${ }^{2}$ See Eric Goldman, Unregulating Online Harassment, 87 DENV. U. L. REV. ONLINE 59 (2010); Eric Goldman, Sex Trafficking Exceptions to Section 230, SANTA CLARA UNIV. LEGAL STUDIES RESEARCH PAPER No. 13-71 (Sept. 20, 2017), https://ssrn.com/abstract=3038632; Eric Goldman, Balancing Section 230 and Anti-Sex Trafficking Initiatives (Dec. 1, 2017), https://ssrn.com/abstract=3079193.




\section{Remedies Analysis}

Tort Damages. We identified at least eighteen cases where the court awarded damages that were not overturned on appeal. Additional cases resulted in a settlement with payment to the victim, but we did not include them in the table below. We did not include attorneys' fees except where noted, but some of these cases also had awards of fees and costs in addition to damages. Some of the damages were awarded in default judgments, where the amounts might have received more scrutiny in contested cases. We enumerate the court's initial award; subsequent proceedings may have adjusted the numbers.

The following table enumerates the cases:

\begin{tabular}{|l|l|l|l|}
\hline \multicolumn{1}{|c|}{ Case } & \multicolumn{1}{|c|}{$\begin{array}{c}\text { Regular } \\
\text { Damages }\end{array}$} & \multicolumn{1}{|c|}{$\begin{array}{c}\text { Punitive } \\
\text { Damages }\end{array}$} & \multicolumn{1}{|c|}{$\begin{array}{c}\text { Initial } \\
\text { Award53 }\end{array}$} \\
\hline Bollea & $\$ 115,000,000$ & $\$ 25,000,000$ & $\$ 140,000,000$ \\
\hline Leviston & $\$ 5,000,000$ & $\$ 2,000,000$ & $\$ 7,000,000$ \\
\hline Backlund & $\$ 500,320$ & $\$ 500,000$ & $\$ 1,000,320$ \\
\hline Conklin & $\$ 1,000,000$ & & $\$ 1,000,000$ \\
\hline Talley (2 defendants) & $\$ 600,000$ & $\$ 300,000$ & $\$ 900,000$ \\
\hline Del Mastro & $\$ 531,000$ & & $\$ 531,000$ \\
\hline Taylor & $\$ 425,000$ & & $\$ 425,000$ \\
\hline Thomas & $\$ 300,000$ & $\$ 125,000$ & $\$ 425,000$ \\
\hline Bollaert (civil case) & $\$ 310,000$ & $\$ 75,000$ & $\$ 385,000$ \\
\hline Patel & $\$ 345,000$ & & $\$ 345,000$ \\
\hline Prezioso & $\$ 300,000$ & & $\$ 300,000$ \\
\hline Bruce & $\$ 250,000$ & & $\$ 250,000$ \\
\hline Hudson & $\$ 225,000$ & & $\$ 225,000$ \\
\hline Hofstetter & $\$ 155,000$ & & $\$ 155,000$ \\
\hline Hoewischer & $\$ 50,000$ & $\$ 100,000$ & $\$ 150,000$ \\
\hline Moldofsky $(2$ plaintiffs $)$ & $\$ 25,500$ & $\$ 30,000$ & $\$ 55,500$ \\
\hline Grossman & $\$ 25,000$ & & $\$ 25,000$ \\
\hline D.C. & $\$ 14,89154$ & & $\$ 14,891$ \\
\hline Vafaie & Indeterminate & & \\
\hline Total & $\$ 124,056,711$ & $\$ 28,130,000$ & $\$ 153,186,711$ \\
\hline
\end{tabular}

\footnotetext{
53 Although we tried to ensure that the damages amounts related solely to the nonconsensual pornography dissemination, these numbers may include damages for other claims.

54 This total includes attorneys' fees.
} 
The bottom-line totals are skewed by Bollea and Leviston, which together account for over ninety-six percent of the aggregate damages.

The totals do not necessarily reflect the amounts plaintiffs actually received. For example, defendants may have defaulted, or the parties may have subsequently settled for less (or more) than the awarded damages.

The number of punitive damages awards is noteworthy. Punitive damages are rarely awarded, 55 but our compilation suggests that punitive damage awards are fairly common in nonconsensual pornography dissemination cases. This reinforces that such cases routinely involve egregious and abusive behavior by defendants.

Consequences of Bankruptcy. Tort remedies for nonconsensual pornography dissemination are sometimes considered inadequate because defendants may be judgment-proof, plus defendants might avoid large damages awards by declaring bankruptcy. ${ }^{56}$ Although these concerns are valid, we found two cases (Grossman and Hoewischer) where bankruptcy courts held that the defendants could not discharge nonconsensual pornography damages awards in bankruptcy. Furthermore, in two other high-profile cases (Leviston and Bollea), the plaintiffs were paid millions of dollars even though the defendants declared bankruptcy. These results suggest that nonconsensual pornography dissemination defendants cannot reliably use bankruptcy to avoid damages.

Criminal Sentences. As Representative Speier's remarks illustrate, there is a widespread view that there are not enough criminal laws against nonconsensual pornography, and the criminal enforcement system does not take these crimes seriously.57 Our compilation includes at least 30 defendants who have received jail sentences for nonconsensual pornography dissemination, plus another seven defendants who were convicted with probation, a diversion agreement, or a sentence that we could not determine. The following

\footnotetext{
55 For example, a 2011 study by the Bureau of Justice Statistics showed that "[p]unitive damages were awarded in $700(5 \%)$ of the 14,359 trials where plaintiffs prevailed." Bureau Of Justice Statistics, Punitive Damages In Civil Trials (June 7, 2011), https://www.bjs.gov/index.cfm?ty=tp\&tid=45111 [https://perma.cc/69G9-9TBMM].

${ }^{56}$ See Citron \& Franks, supra note 22, at 357-59.

57 Danielle K. Citron, Law's Expressive Value in Combating Cyber Gender Harassment, 108 MiCH. L. REV. 373, 403 (2009).
} 
table enumerates these actions by the initially imposed sentence, which may have subsequently changed: 58

\begin{tabular}{|c|c|c|c|}
\hline Case & Incarceration & $\begin{array}{c}\text { Other Punishments } \\
\text { (where known) }\end{array}$ & Notes \\
\hline Hutchinson & Life & & Child victim \\
\hline Shea & 396 months & & Child victim \\
\hline Kisling & $\begin{array}{l}240 \text { months (and } \\
180 \text { months } \\
\text { concurrent) }\end{array}$ & $\begin{array}{l}\text { Life term of supervised } \\
\text { release }\end{array}$ & Child victim \\
\hline Bollaert & 216 months & $\begin{array}{l}\$ 15, \text { ooo restitution; } \\
\$ 10, \text { ooo fine }\end{array}$ & \\
\hline Yarber & $\begin{array}{l}180 \text { months }(84 \\
\text { months } \\
\text { minimum) }\end{array}$ & & \\
\hline Stancl & 180 months & $\begin{array}{l}13 \text { years supervised } \\
\text { release, no contact } \\
\text { order, sex offender } \\
\text { registration }\end{array}$ & Child victim \\
\hline Schnitker & 168 months & & Child victim \\
\hline Azzara & 168 months & $\begin{array}{l}3 \text { years supervised } \\
\text { release, } \$ 300 \text { special } \\
\text { assessment }\end{array}$ & \\
\hline Ybarra & 148 months & & \\
\hline Dula & 120 months & $\$ 10,000$ fine & \\
\hline Beckett & 120 months & $\begin{array}{l}\text { Lifetime supervised } \\
\text { release }\end{array}$ & Child victim \\
\hline Petrovic & 96 months & & \\
\hline Esler & 70 months & $\begin{array}{l}20 \text { years supervised } \\
\text { release, } \$ 37,750 \\
\text { restitution }\end{array}$ & Child victim \\
\hline Sayer & 60 months & & \\
\hline Osinger & 46 months & & \\
\hline Meyering & 36 months & & \\
\hline Brown & 36 months & & \\
\hline Ackell & 33 months & $\begin{array}{l}3 \text { years supervised } \\
\text { release, } \$ 100 \text { special } \\
\text { assessment }\end{array}$ & \\
\hline Moore & $\begin{array}{l}30 \text { months } \\
\text { (Moore), } \\
25 \text { months }\end{array}$ & $\begin{array}{l}\text { Evens: } \$ 2,000 \text { fine, } 20 \\
\text { hours of community } \\
\text { service. Both: } \$ 147.50\end{array}$ & \\
\hline
\end{tabular}

$5^{8}$ Some sentences were later reduced, some defendants did not actually serve the full sentence, and some defendants did not spend time in jail at all. 


\begin{tabular}{|c|c|c|c|}
\hline Case & Incarceration & $\begin{array}{l}\text { Other Punishments } \\
\text { (where known) }\end{array}$ & Notes \\
\hline & (Evens) & restitution & \\
\hline Ledgard & 25 months & $\begin{array}{l}3 \text { years supervised } \\
\text { release }\end{array}$ & \\
\hline Kushner & 24 months & $\begin{array}{l}2 \text { years supervised } \\
\text { release, } \$ 4,000 \text { fine, } \\
\$ 100 \text { special } \\
\text { assessment }\end{array}$ & \\
\hline Cavazos & $\begin{array}{l}24 \text { months (and } \\
237 \text { days } \\
\text { concurrent) }\end{array}$ & & \\
\hline Kochanowski & 12 months & & \\
\hline Piznarski & $\begin{array}{l}\text { 12-36 months } \\
\text { (and other } \\
\text { shorter } \\
\text { concurrent) }\end{array}$ & $\begin{array}{l}\text { Protective order, Level } \\
1 \text { sex offender }\end{array}$ & \\
\hline J.O. & 6 months & $\begin{array}{l}3 \text { years conditional } \\
\text { release, no contact with } \\
\text { family }\end{array}$ & $\begin{array}{l}\text { Juvenile } \\
\text { defendant }\end{array}$ \\
\hline Barber & 6 months & 5 years & \\
\hline Kuhl & 6 months & 2 years & $\begin{array}{l}\text { We could not } \\
\text { determine co- } \\
\text { defendant } \\
\text { Hakes' } \\
\text { sentence }\end{array}$ \\
\hline Roebuck & 3-23 months & $\begin{array}{l}3 \text { years probation, sex } \\
\text { offender registration, } \\
\$ 660 \text { restitution }\end{array}$ & \\
\hline Pauling & 3 months & $\begin{array}{l}\text { No contact with victim; } \\
\text { domestic violence } \\
\text { treatment program; } \\
\text { costs of } \$ 2,861.32\end{array}$ & \\
\hline Roller & & 3 years probation & $\begin{array}{l}\text { Probation } \\
\text { revoked for } \\
\text { recidivism } \\
\end{array}$ \\
\hline Butler & & 3 years probation & \\
\hline Tarlow & & Diversion agreement & \\
\hline Franklin & & Indeterminate & \\
\hline Hutson & & Indeterminate & \\
\hline Morehead & & Indeterminate & \\
\hline Parsons & & Indeterminate & \\
\hline Wood & & Indeterminate & \\
\hline
\end{tabular}


Unsurprisingly, many of the cases with the longest sentences involve child victims, but the table includes some substantial sentences in cases without child victims. We enumerate four such cases that have sentences of ten years or longer. Bollaert's sentence particularly stands out because it highlights the significant exposure faced by intermediaries if they are not protected by Section 230's immunity.

Injunctions. We compiled at least fourteen actions that produced some form of injunction, 59 such as a restraining order, protective order, or substantive restriction on disseminating materials.

\section{Policy Analysis}

Ultimately, we aspire to answer the question: what package of legal regulation would optimally address the problems with nonconsensual pornography dissemination? To answer that question, we might run three comparisons:

Condition \#1 (the baseline): existing laws excluding any sui generis nonconsensual pornography laws. Though we included some cases predicated on the sui generis laws, our compilation basically models this condition.

Condition \#2 (the status quo): Condition \#1 plus the state sui generis laws. Although not every state has adopted a sui generis law, this is essentially the status quo.

Condition \#3 (expanded regulation): Condition \#2 plus a new federal sui generis law, such as the ENOUGH Act.

In an ideal world, we could model all three conditions side-by-side and compare the results before picking the best one. In the real world, we do not get to run rigorous A/B tests like this. Still, this article provides some data to inform condition \#1. For example, the compilation shows that dozens of existing laws (excluding the sui generis laws) apply to nonconsensual pornography dissemination, dozens of people have gone to jail based on existing laws, and significant civil damages have been awarded.

We know less about the consequences of the sui generis laws. For example, we found reports indicating the sui generis laws have led to

\footnotetext{
59 Backlund (injunction against defamation), Christman Hubbard (restriction on dissemination), Clarke (protective order), Conklin, D.C., Hofstetter, Kid Rock, L.Z. (restraining order), McGowan (restraining order), Miranda, Osno (restraining order), S.B. (restraining order), Talley, and Williams.
} 
at least ten prosecutions in Hawaii6o and four prosecutions in Minnesota. ${ }^{61}$ Extrapolating these fourteen prosecutions to other states that have adopted sui generis laws, the number of prosecutions under the sui generis laws likely already exceeds-possibly by a lot-the number of actions in our compilation. Projecting into the future, the number of sui generis enforcements may dominate all other bases for nonconsensual pornography dissemination enforcement.

Unfortunately, significant enforcement of the state sui generis laws does not confirm that the enforcement activity is beneficial. Perhaps more perpetrators are being brought to justice more efficiently; but perhaps law enforcement is spending more time on investigations and prosecutions that are not meritorious, or perhaps the new laws do not meaningfully change the results that would have been achieved in Condition \#1.62 The sui generis laws and their enforcement also raise substantial First Amendment concerns ${ }^{63}$ and may have an unintentional negative disparate impact on non-majority subcommunities. ${ }^{64}$ Clearly, we need more data and transparency about usage of the sui generis laws so we can evaluate them better.

\footnotetext{
${ }^{60}$ Lynn Kawano, Former UH Athlete Charged Under Rarely-Used 'Revenge Porn' Law, KFVE (Oct. 27, 2016), http://www.k5thehometeam.com/story/33502882/man-accusedof-kidnapping-sex-assault-also-charged-under-revenge-porn-law [https://perma.cc/3BLM-PJZ8] (saying there have been nine prosecutions pursuant to Hawaii's revenge porn law, and discussing the prosecution of a tenth defendant, Joseph Uglietto).

${ }^{61}$ Sarah Horner, Anoka Man Charged Under New 'Revenge Porn' Law For Posting Nudes of Ex, Charges Say, Twin CiTIEs PiONEER Press (Feb. 28, 2017, 7:05 PM), http://www.twincities.com/2017/o2/28/anoka-man-posted-nude-photos-of-his-ex-onfake-facebook-page-charges-say/ [https://perma.cc/STU6-7BGK].

${ }^{62}$ See Eric Goldman, California's New Law Shows It's Not Easy To Regulate Revenge Porn, TECH. \& MKTG. L. BLOG (Oct. 16, 2013), http://blog.ericgoldman.org/archives/2013/10/californias_new_1.htm [https://perma.cc/7SUA-LPL4].
}

${ }^{63}$ For example, Arizona's first sui generis law was not enforceable due to constitutionality concerns. See Antigone Books, LLC v. Horne, No. 2:14-cv-02100-PHX-SRB (D. Ariz. July 10, 2015) (Az. final decree). Rhode Island's governor vetoed a sui generis law for the same reason. Katherine Gregg, Governor Says She Worries About Its Broad Sweep and 'Chilling Effect on Free Speech, PROVIDENCE J. (June 21, 2016), http://www.providencejournal.com/news/20160621/raimondo-vetoes-revenge-porn-bill [https://perma.cc/JFH7-W7NV] (citing concerns that the law would reach the news media and works of art depicting the human body).

${ }^{64} C f$. Amy A. HASINOFF, SEXTING PANIC (2015) (discussing the disproportionate enforcement of anti-sexting laws against marginalized groups); ROGER N. LANCASTER, SEX 
As for condition $\# 3$, we wonder what unresolved problems in conditions \#1 and \#2 would require federal regulatory intervention, especially given the wide range of doctrinal tools that have been successfully deployed. We also wonder if additional criminalization is the best way to redress the underlying cultural and social roots of the problem. ${ }^{65}$

\section{CONCLUSION}

Many victims of nonconsensual pornography dissemination have horrific stories, including the stories behind many of the cases compiled in this article. It is essential that we not lose sight of victims' personal stories. At the same time, basing regulatory solutions on individual narratives can lead to suboptimal outcomes.

To supplement the individual narratives and probe the validity of some stereotypes, this article aggregates data from actual litigation involving nonconsensual pornography dissemination. Ideally, this article will contribute to efforts to gather more empirical data about the nonconsensual pornography dissemination phenomenon and how the law is handling it. That effort should help regulators make wellinformed choices.

PANiC AND THE Punitive STATE (2011) (discussing the disproportionate effects of sex offender laws on gay men).

${ }^{65}$ As Prof. Edwards explained: "Long term revenge porn ... is not a criminal law problem but a social problem. We need, by education in schools and homes, by peer pressure and, most immediately, by swift and resolute response from hosting social networks, to show that this behavior is unacceptable." Edwards, supra note 32. See also Meiselman, supra note 22 ("[R]evenge porn...is a conduct problem, it is a criminal problem, and unfortunately it is a cultural problem"). 


\section{APPENDIX A}

\section{OFFLINE DISSEMINATION}

\begin{tabular}{|c|c|c|}
\hline Case Name & Key Facts & Outcome \\
\hline $\begin{array}{l}\text { Hudson } v \text {. } \\
\text { Montcalm Pub. } \\
\text { Corp. }{ }^{66}\end{array}$ & $\begin{array}{l}\text { Gordon and the victim were } \\
\text { married. After they split, } \\
\text { Gordon submitted a nude } \\
\text { photo of her to Montcalm } \\
\text { for publication, along with a } \\
\text { forged publication consent } \\
\text { form. Montcalm published } \\
\text { the photo in its magazine. }\end{array}$ & $\begin{array}{l}\text { The invasion of privacy claim } \\
\text { against Gordon succeeded, } \\
\text { and the plaintiffs were } \\
\text { awarded } \$ 225,000 .{ }^{67} \\
\text { Despite the bogus consent } \\
\text { form, Montcalm avoided } \\
\text { liability based on a valid } \\
\text { release signed after the } \\
\text { photo was published. }\end{array}$ \\
\hline In re Thomas ${ }^{68}$ & $\begin{array}{l}\text { Ex-boyfriend mailed } \\
\text { sexually explicit } \\
\text { consensually-created photos } \\
\text { to victim's fiancé. }\end{array}$ & $\begin{array}{l}\text { The court found IIED and } \\
\text { awarded } \$ 300,000 \text { in actual } \\
\text { damages and } \$ 125,000 \text { in } \\
\text { punitive damages. }\end{array}$ \\
\hline $\begin{array}{l}\text { State } v . \\
\text { Pauling }\end{array}$ & $\begin{array}{l}\text { Ex-boyfriend mailed } \\
\text { sexually explicit photos to at } \\
\text { least } 20 \text { of victim's co- } \\
\text { workers, friends, and } \\
\text { neighbors after threatening } \\
\text { to do so to get a debt paid. }\end{array}$ & $\begin{array}{l}\text { The lower court convicted } \\
\text { defendant of extortion and } \\
\text { sentenced him to } 90 \text { days in } \\
\text { county jail on two counts- } \\
\text { the sentences ran } \\
\text { concurrently. He was } \\
\text { barred from contacting the } \\
\text { victim and ordered to } \\
\text { attend a domestic violence } \\
\text { treatment program. He was } \\
\text { also ordered to pay } \\
\$ 2,861.32 \text { in costs. } \\
\text { On appeal, the Washington } \\
\text { Supreme Court agreed that } \\
\text { the statute was overbroad, } \\
\text { but upheld the conviction }\end{array}$ \\
\hline
\end{tabular}

66 Hudson v. Montcalm Pub. Corp., 190 Ga. App. 629 (1989), 379 S.E.2d 572 (Ga.App. 1989).

${ }^{67}$ Hudson v. Windholz, 202 Ga. App. 882 (1992), 416 S.E.2d 120 (Ga.App 1992).

68 In re Thomas, 254 B.R. 879 (D.S.C. 1999).

69 State v. Pauling, 69 P.3d 331 (Wash. 2003); Pauling v. McKenna, No. C04-2203C, 2005 WL 3132213 (W.D. Wash. Nov. 22, 2005). 


\begin{tabular}{|c|c|c|}
\hline Case Name & Key Facts & Outcome \\
\hline & & $\begin{array}{l}\text { because the defendant } \\
\text { threatened the victim to } \\
\text { extract payment. A federal } \\
\text { district court denied his } \\
\text { habeas corpus petition. }\end{array}$ \\
\hline $\begin{array}{l}\text { United States } \\
v . \text { Kushner }{ }^{70}\end{array}$ & $\begin{array}{l}\text { The government investigated } \\
\text { the defendant's conduct. To } \\
\text { retaliate against a cooperating } \\
\text { witness, the defendant had a } \\
\text { prostitute seduce the witness } \\
\text { and surreptitiously record } \\
\text { their sexual activity. The } \\
\text { defendant then had the } \\
\text { recording sent to the witness' } \\
\text { wife. }\end{array}$ & $\begin{array}{l}\text { The defendant was charged } \\
\text { with witness retaliation (18 } \\
\text { U.S.C. } \$ 1513(\mathrm{e})) \text {. The } \\
\text { defendant entered into a } \\
\text { plea agreement. He was } \\
\text { sentenced to two years in } \\
\text { prison, two years of } \\
\text { supervised release, a } \\
\$ 4, \text { ooo fine, and a } \$ 100 \\
\text { special assessment. }\end{array}$ \\
\hline $\begin{array}{l}\text { McGowan v. } \\
\text { O'Rourke }{ }^{71}\end{array}$ & $\begin{array}{l}\text { Defendant mailed sexually } \\
\text { explicit photos to victim's } \\
\text { sister and threatened to } \\
\text { send photos to her co- } \\
\text { workers and son. }\end{array}$ & $\begin{array}{l}\text { Lewdness and stalking } \\
\text { charges were dismissed, but } \\
\text { lower court issued a Final } \\
\text { Restraining Order based on } \\
\text { harassment. The appeals } \\
\text { court affirmed. }\end{array}$ \\
\hline $\begin{array}{l}\text { Del Mastro v. } \\
\text { Grimado }^{72}\end{array}$ & $\begin{array}{l}\text { Ex-boyfriend disseminated } \\
\text { sexually explicit photos to } \\
\text { victim's family, friends, and } \\
\text { business clients. }\end{array}$ & $\begin{array}{l}\text { The lower court found } \\
\text { defendant guilty of IIED and } \\
\text { invasion of privacy, and } \\
\text { awarded over } \$ 531,000 \text { in } \\
\text { damages. The appeals court } \\
\text { affirmed. } \\
\text { The defendant allegedly } \\
\text { avoided payment by } \\
\text { fraudulently transferring } \\
\text { assets, and the lower court } \\
\text { found the victim's subsequent } \\
\text { suit over the asset transfer } \\
\text { barred by the statute of } \\
\text { limitations. The appeals court }\end{array}$ \\
\hline
\end{tabular}

70 United States v. Kushner, No. 2:04-cr-00580 (D.N.J. Aug. 18, 2004); United States v. Kushner, No. 2:04-mj-06120 (D.N.J. July 12, 2004).

${ }^{71}$ McGowan v. O'Rourke, 391 N.J. Super. 502, 918 A.2d 716 (App. Div. 2007).

72 Del Mastro v. Grimado, 2010 N.J. Super. Unpub. LEXIS 2315 (Ch. Div. Mar. 8, 2010); Del Mastro v. Grimado, No. A-1433-11T4, 2013 N.J. Super. Unpub. LEXIS 2204 (App. Div. Sept. 5, 2013). 


\section{APPENDIX B}

\section{ONLINE DISSEMINATION}

\begin{tabular}{|c|c|c|}
\hline Case Name & Key Facts & Outcome \\
\hline $\begin{array}{l}\text { People } v . \\
\text { Kochanowski } 73\end{array}$ & $\begin{array}{l}\text { Ex-boyfriend helped } \\
\text { to create a website } \\
\text { with "suggestive" } \\
\text { photos of the victim } \\
\text { and included her } \\
\text { contact information. }\end{array}$ & $\begin{array}{l}\text { Defendant was convicted of } \\
\text { aggravated harassment in the } \\
\text { second degree (N.Y. Penal Law } \S \\
240.30 \text { ). He was sentenced to one } \\
\text { year in prison. }\end{array}$ \\
\hline Osno v. Klein 74 & $\begin{array}{l}\text { The parties had an } \\
\text { intimate relationship. } \\
\text { Plaintiff sought } \\
\text { restraining order } \\
\text { after the defendant } \\
\text { told the plaintiff that } \\
\text { he had posted } \\
\text { sexually explicit } \\
\text { videos of her on the } \\
\text { Internet. }\end{array}$ & $\begin{array}{l}\text { The court issued a restraining } \\
\text { order against the defendant } \\
\text { under the Prevention of Domestic } \\
\text { Violence Act (N.J.S.A. § } 2 \text { C: } 25-17 \\
\text { to } 35 \text { ). The appeals court } \\
\text { affirmed. }\end{array}$ \\
\hline $\begin{array}{l}\text { Peterson } v . \\
\text { Moldofsky }\end{array}$ & $\begin{array}{l}\text { The parties had an } \\
\text { intimate relationship, } \\
\text { during which the } \\
\text { defendant took } \\
\text { explicit photos of the } \\
\text { victim having sex } \\
\text { with other people. } \\
\text { After they 'had a } \\
\text { falling out,' the } \\
\text { defendant emailed } \\
\text { explicit photos of the } \\
\text { victim to the victim's }\end{array}$ & $\begin{array}{l}\text { The victim and her mother } \\
\text { claimed IIED, invasion of privacy, } \\
\text { intrusion upon seclusion, and } \\
\text { public disclosure of private facts. } \\
\text { The court dismissed the intrusion } \\
\text { into seclusion claim on summary } \\
\text { judgment. The other claims } \\
\text { proceeded to a jury. The jury } \\
\text { found for the plaintiffs and } \\
\text { awarded the victim actual } \\
\text { damages of } \$ 18,000 \text { and punitive } \\
\text { damages of } \$ 25,000 \text {, and further }\end{array}$ \\
\hline
\end{tabular}

73 People v. Kochanowski, 719 N.Y.S.2d 461 (2d Dep’t. 200o).

74 Osno v. Klein, No. A-1040-06T2, 2007 N.J. Super. Unpub. LEXIS 115 (App. Div. July 10, 2007).

75 Peterson v. Moldofsky, No. 07-2603-EFM, 2009 WL 3126229 (D. Kan. Sept. 29, 2009). See Kashmir Hill, Ex Must Pay Piper Peterson and Her Mom \$55,5oo for E-Mailing Group Sex Photos, Forbes: The NOT-So PRIVATE PARTS BLOG (Nov. 10, 2009), http://www.forbes.com/sites/kashmirhill/2009/11/10/piper-peterson-and-motherawarded-55000-for-group-sex-photos [https://perma.cc/AFN4-SQ9E]. 


\begin{tabular}{|c|c|c|}
\hline Case Name & Key Facts & Outcome \\
\hline & $\begin{array}{l}\text { family members, } \\
\text { current boyfriend, } \\
\text { and coworkers. }\end{array}$ & $\begin{array}{l}\text { awarded the victim's mother } \\
\text { actual damages of } \$ 7,500 \text { and } \\
\text { punitive damages of } \$ 5,000 \text {. }\end{array}$ \\
\hline $\begin{array}{l}\text { Miranda } v . \\
\text { Guerrero }^{76}\end{array}$ & $\begin{array}{l}\text { The defendant took } \\
\text { photos of the victim } \\
\text { intended solely for } \\
\text { publication in } \\
\text { Playboy magazine. } \\
\text { The Playboy } \\
\text { publication } \\
\text { opportunity did not } \\
\text { materialize. The } \\
\text { defendant then } \\
\text { threatened to publish } \\
\text { the photos on the } \\
\text { Internet if the victim } \\
\text { did not pay her } \\
\$ 70, \text { ooo. When the } \\
\text { victim refused, the } \\
\text { defendant set up a } \\
\text { website pretending to } \\
\text { be the victim's } \\
\text { official website and } \\
\text { posted multiple nude } \\
\text { photos. }\end{array}$ & $\begin{array}{l}\text { Based on her Lanham Act false } \\
\text { designation of origin claim ( } 15 \\
\text { U.S.C. } \S 1125(a) \text { ), the court issued } \\
\text { an injunction against the website, } \\
\text { including an injunction on } \\
\text { "[p]ublishing, printing, displaying } \\
\text { or otherwise publicly using any } \\
\text { image or photograph of Plaintiff." }\end{array}$ \\
\hline Roller v. State 77 & $\begin{array}{l}\text { Ex-boyfriend created } \\
\text { a fake MySpace } \\
\text { profile in victim's } \\
\text { name and posted } \\
\text { explicit photos of her } \\
\text { taken during their } \\
\text { relationship. }\end{array}$ & $\begin{array}{l}\text { Defendant was convicted of } \\
\text { fraudulent use and possession of } \\
\text { identifying information (Tex. } \\
\text { Penal Code } \S 32.51 \text { ) and placed } \\
\text { on three years' probation. The } \\
\text { court revoked the probation when } \\
\text { it was discovered he had posted } \\
\text { more explicit photos to } \\
\text { www.oneclickchicks.com. The } \\
\text { appeals court affirmed. }\end{array}$ \\
\hline $\begin{array}{l}\text { Taylor } v . \\
\text { Franko }^{78}\end{array}$ & $\begin{array}{l}\text { Ex-boyfriend } \\
\text { disseminated } \\
\text { sexually explicit }\end{array}$ & $\begin{array}{l}\text { The victim sued for public } \\
\text { disclosure of private facts, } \\
\text { defamation, NIED and IIED. The }\end{array}$ \\
\hline
\end{tabular}

\footnotetext{
${ }^{76}$ Miranda v. Guerrero, No. 08-22326-CIV, 2009 WL 1381250 (S.D. Fla. May 14, 2009).

77 Roller v. State, No. 13-09-00175-CR, 2010 Tex. App. LEXIS 5522 (July 15, 2010).

${ }^{78}$ Taylor v. Franko, No. 09-00o02 JMS/RLP, 2011 WL 2746714 (D. Haw. June 12, 2011).
} 


\begin{tabular}{|c|c|c|}
\hline Case Name & Key Facts & Outcome \\
\hline & $\begin{array}{l}\text { photos (given to him } \\
\text { by the victim) on } \\
\text { Internet sites, } \\
\text { including Craigslist, } \\
\text { along with the } \\
\text { victim's personal } \\
\text { information and } \\
\text { solicitations for sex. }\end{array}$ & $\begin{array}{l}\text { defendant defaulted. The judge } \\
\text { awarded damages of } \$ 425,000 \text {. }\end{array}$ \\
\hline $\begin{array}{l}\text { State } v . \\
\text { Roebuck }\end{array}$ & $\begin{array}{l}\text { The parties dated, } \\
\text { and the defendant } \\
\text { made videos of them } \\
\text { having sex. After they } \\
\text { broke up, he posted } \\
\text { one of the videos } \\
\text { online. }\end{array}$ & $\begin{array}{l}\text { Defendant pleaded guilty to } \\
\text { selling obscene/sexual materials } \\
\text { and to harassment. He was } \\
\text { sentenced to } 3-23 \text { months in jail, } \\
\text { with a minimum of twelve } \\
\text { consecutive weekends with } \\
\text { electronic monitoring during the } \\
\text { week, followed by three years of } \\
\text { probation. Defendant also had to } \\
\text { attend sex offender classes and } \\
\text { pay } \$ 660 \text { in restitution for } \\
\text { victim's therapy bills. }\end{array}$ \\
\hline State v. Parsons ${ }^{80}$ & $\begin{array}{l}\text { While dating, the } \\
\text { parties exchanged } \\
\text { nude photos with the } \\
\text { understanding that } \\
\text { the photos were not } \\
\text { to be shared with } \\
\text { others. After they } \\
\text { broke up, the } \\
\text { defendant threatened } \\
\text { to disseminate the } \\
\text { photos to the victim's } \\
\text { employer, which he } \\
\text { ultimately did. }\end{array}$ & $\begin{array}{l}\text { The defendant was charged with } \\
\text { third-degree invasion of privacy } \\
\text { under New Jersey's revenge porn } \\
\text { law (N.J. Stat. § 2C:14-9). The } \\
\text { trial court denied a motion to } \\
\text { dismiss and the defendant } \\
\text { entered a plea. The appeals court } \\
\text { affirmed. }\end{array}$ \\
\hline $\begin{array}{l}\text { State } v . \\
\text { Franklin } \\
\end{array}$ & $\begin{array}{l}\text { The defendant posted } \\
\text { sexually explicit }\end{array}$ & $\begin{array}{l}\text { A jury convicted the defendant of } \\
\text { stalking, cyberstalking, and }\end{array}$ \\
\hline
\end{tabular}

79 Facts from

http://roam.co.delaware.pa.us/delco/search.do?indexName=delcoimages\&lq=EventEntry ID\%3A3466680 [https://perma.cc/7BK5-EZEQ]. See also case cited infra note 82.

8o State v. Parsons, No. A-3856-10T3, 2011 N.J. Super. Unpub. LEXIS 2972 (Super. Ct. App. Div. Dec. 8, 2011).

${ }^{81}$ State v. Franklin, No. 64033-0-I, 2012 Wash. App. LEXIS 451 (Wash. Ct. App. Mar. 5, 2012). 


\begin{tabular}{|c|c|c|}
\hline Case Name & Key Facts & Outcome \\
\hline & $\begin{array}{l}\text { photos of the victim } \\
\text { on Craigslist with her } \\
\text { contact information. }\end{array}$ & $\begin{array}{l}\text { perjury. The appeals court } \\
\text { affirmed. }\end{array}$ \\
\hline $\begin{array}{l}\text { Roebuck v. } \\
\text { Scott }^{82}\end{array}$ & $\begin{array}{l}\text { Same facts as State } v . \\
\text { Roebuck. }\end{array}$ & $\begin{array}{l}\text { The victim sued for invasion of } \\
\text { privacy, NIED, IIED, and } \\
\text { negligence. The case settled. }\end{array}$ \\
\hline $\begin{array}{l}\text { United States } v \text {. } \\
\text { Ledgard }^{8} 3\end{array}$ & $\begin{array}{l}\text { The parties dated. } \\
\text { After they broke up, } \\
\text { the defendant } \\
\text { engaged in a } \\
\text { campaign to } \\
\text { "destroy" the victim's } \\
\text { life-which included } \\
\text { emailing nude photos } \\
\text { to the victim's father, } \\
\text { the admissions } \\
\text { department of a } \\
\text { university where the } \\
\text { victim had applied, } \\
\text { and the victim's } \\
\text { friends. }\end{array}$ & $\begin{array}{l}\text { The district court convicted the } \\
\text { defendant of several Computer } \\
\text { Fraud \& Abuse Act counts (18 } \\
\text { U.S.C. § 1030). The victim's } \\
\text { severe emotional distress } \\
\text { provided support for the CFAA } \\
\text { conviction. The court explained: } \\
\text { "[I]t is hard to imagine something } \\
\text { more emotionally traumatic and } \\
\text { devastating to a young woman } \\
\text { living with her parents, with a } \\
\text { traditional cultural background, } \\
\text { then finding out that private } \\
\text { pornographic photos of her } \\
\text { engaging in sex acts with } \\
\text { someone she had loved and } \\
\text { trusted were sent by him to her } \\
\text { father, as well as numerous other } \\
\text { people she knew." } 84 \text { The } \\
\text { defendant was also convicted of } \\
\text { aggravated identify theft. The } \\
\text { appeals court affirmed. He was } \\
\text { sentenced to twenty-five months } \\
\text { in prison plus three years of }\end{array}$ \\
\hline
\end{tabular}

82 Roebuck v. Scott, No. 2012-006627 (Pa. Ct. Com. Pl. filed Aug. 2, 2012), http://roam.co.delaware.pa.us/delco/search.do?indexName=docketcase\&templateName= case\&lq=CASE_NUMBER\%3A\%222012-006627\%22 [https://perma.cc/CVZ5-99QT]. See also, Jilted Boyfriend Arrested for X-Rated Upload, THE SMOKING GuN (Nov. 16, 2011), http://www.thesmokinggun.com/documents/ex-posts-explicit-video-765319 [https://perma.cc/8YAV-5KMZ].

83 United States v. Ledgard, No. CR 08-00982 (B) DDP, 2012 U.S. Dist. LEXIS 130204 (C.D. Cal. Sept. 12, 2012); United States v. Ledgard, 583 F. App’x 654 (9th Cir. 2014); United States v. Ledgard, No. 3:15-cr-07127 (S.D. Cal. Oct. 6, 2015); Ledgard v. United States, No. 2:15-cv-08080 (C.D. Cal. Oct. 14, 2015).

84 United States v. Ledgard, No. CR 08-00982 (B) DDP, 2012 U.S. Dist. LEXIS 130204 at *47 (C.D. Cal. Sept. 12, 2012). 


\begin{tabular}{|c|c|c|}
\hline Case Name & Key Facts & Outcome \\
\hline & & supervised release. \\
\hline $\begin{array}{l}\text { Doe } v . \\
\text { Hofstetter } 85\end{array}$ & $\begin{array}{l}\text { The plaintiffs are } \\
\text { married. The } \\
\text { defendant published } \\
\text { two blogs containing } \\
\text { "intimate" photos of } \\
\text { Jane Doe plus false } \\
\text { statements about the } \\
\text { plaintiffs' marriage } \\
\text { and defendant's } \\
\text { relationship with } \\
\text { Jane Doe. The } \\
\text { defendant also } \\
\text { created two fake } \\
\text { Twitter accounts in } \\
\text { Jane Doe's name that } \\
\text { included the photos, } \\
\text { and emailed the } \\
\text { photos to both } \\
\text { plaintiff-victims. }\end{array}$ & $\begin{array}{l}\text { The plaintiff-victims asserted } \\
\text { numerous claims, including } \\
\text { ECPA (18 U.S.C. § 2510), CFAA } \\
\text { (18 U.S.C. § 1030), SCA (18 U.S.C. } \\
\S \text { 2701), IIED, intrusion into } \\
\text { seclusion, public disclosure of } \\
\text { private facts, stalking (C.R.S. § } \\
\text { 18-3-602) and harassment } \\
\text { (C.R.S. § 18-9-111). The defendant } \\
\text { defaulted. The court granted } \\
\text { judgment for the IIED and public } \\
\text { disclosure of private facts claims, } \\
\text { awarded the plaintiffs damages of } \\
\$ 155, \text { ooo, and issued an } \\
\text { injunction that included no } \\
\text { contact with the plaintiffs, no } \\
\text { further posting of photos about } \\
\text { them, deletion of the photos, and } \\
\text { no impersonation of them. }\end{array}$ \\
\hline $\begin{array}{l}\text { United States } v . \\
\text { Petrovic }^{86}\end{array}$ & $\begin{array}{l}\text { The parties dated, } \\
\text { married, and then } \\
\text { divorced. During } \\
\text { their relationship, } \\
\text { the parties created } \\
\text { sexually explicit } \\
\text { material, both with } \\
\text { and without the } \\
\text { victim's consent. } \\
\text { After the victim } \\
\text { ended the } \\
\text { relationship, the } \\
\text { defendant threatened } \\
\text { to disseminate the } \\
\text { material. The } \\
\text { defendant carried out } \\
\text { his threat, launching }\end{array}$ & $\begin{array}{l}\text { After a trial, the defendant was } \\
\text { convicted of } 4 \text { counts of interstate } \\
\text { stalking ( } 18 \text { U.S.C. } \S 2261 \mathrm{~A}(2)(\mathrm{A}) \text { ) } \\
\text { and } 2 \text { counts of interstate } \\
\text { extortionate threats ( } 18 \text { U.S.C. } \S \\
875(d) \text { ). The court sentenced him } \\
\text { to } 96 \text { months in prison. The } \\
\text { appeals court affirmed. }\end{array}$ \\
\hline
\end{tabular}

85 Doe v. Hofstetter, No. 11-CV-02209-DME-MJW, 2012 WL 2319052 (D. Colo. June 13, 2012); Doe v. Hofstetter, No. 11-CV-02209-DME-MJW, 2012 WL 3398316 (D. Colo. Aug. 14, 2012).

86 United States v. Petrovic, 701 F.3d 849 (8th Cir. 2012); Petrovic v. United States, No: 4:14CV334 HEA, 2015 WL 5853178 (E.D. Mo. Oct. 7, 2015). 


\begin{tabular}{|c|c|c|}
\hline Case Name & Key Facts & Outcome \\
\hline & $\begin{array}{l}\text { a public website } \\
\text { containing sexually } \\
\text { explicit material and } \\
\text { promoting it to the } \\
\text { victim's friends, } \\
\text { family, co-workers, } \\
\text { and neighbors. He } \\
\text { also mailed photos to } \\
\text { the victim's office } \\
\text { and home, her boss, } \\
\text { and her family } \\
\text { members. At one } \\
\text { point, the defendant } \\
\text { offered to shut down } \\
\text { the website if the } \\
\text { victim gave him some } \\
\text { personal property } \\
\text { plus } \$ 100, \text { ooo. }\end{array}$ & \\
\hline Jacobs v. Seay ${ }^{87}$ & $\begin{array}{l}\text { The parties dated. } \\
\text { During their } \\
\text { relationship, the } \\
\text { complaint alleges } \\
\text { Seay "took, obtained } \\
\text { or otherwise } \\
\text { appropriated" } \\
\text { pornographic images } \\
\text { of the plaintiff. After } \\
\text { they broke up, the } \\
\text { complaint alleges } \\
\text { Seay publicly } \\
\text { disseminated } \\
\text { pornographic videos } \\
\text { and photos of the } \\
\text { plaintiff. }\end{array}$ & $\begin{array}{l}\text { Plaintiff sued Seay and various } \\
\text { online websites for invasion of } \\
\text { privacy, public disclosure of } \\
\text { private facts and IIED. The court } \\
\text { denied Seay's motion to } \\
\text { dismiss. } 88 \text { The case settled. } 89\end{array}$ \\
\hline
\end{tabular}

87 Jacobs v. Seay, No. 2013-13626-CA-02 (Fla. Cir. Ct. filed Apr. 13, 2013), https://www.scribd.com/document/138909420/revenge-porn-complaint-holly-jacobs-vsryan-seay [https://perma.cc/EMX3-CPPQ].

88 Jacobs v. Seay, No. 2013-13626-CA-02 (Fla. Cir. Ct. Aug. 25, 2014), http://digitalcommons.law.scu.edu/cgi/viewcontent.cgi?article=2415\&context=historical [https://perma.cc/9X57-Q35B].

${ }^{89}$ Confirmed by an email from defense counsel dated February 10, 2017 (on file with Eric Goldman). 


\begin{tabular}{|c|c|c|}
\hline Case Name & Key Facts & Outcome \\
\hline $\begin{array}{l}\text { State } v . \\
\text { McLellan } 90\end{array}$ & $\begin{array}{l}\text { While dating, the } \\
\text { parties created nude } \\
\text { videos of the victim. } \\
\text { After they broke up, } \\
\text { the victim found the } \\
\text { video was posted } \\
\text { multiple websites. } 91\end{array}$ & $\begin{array}{l}\text { The state charged the defendant } \\
\text { with video voyeurism (I.C. } \S 18- \\
6609(2)(\mathrm{b})) \text {. The lower court } \\
\text { found that the state failed to show } \\
\text { the defendant obtained the videos } \\
\text { with intent to degrade the victim, } \\
\text { so it dismissed the case. The } \\
\text { appeals court affirmed. }\end{array}$ \\
\hline Doe v. Bruce ${ }^{92}$ & $\begin{array}{l}\text { While dating } \\
\text { defendant Bruce, the } \\
\text { victim shared } \\
\text { confidential photos. } \\
\text { After they broke up, } \\
\text { Bruce began dating } \\
\text { co-defendant Rodil. } \\
\text { Rodil uploaded the } \\
\text { victim's photos to a } \\
\text { fake Facebook profile } \\
\text { that she created in } \\
\text { the victim's name. } \\
\text { Many of the victim's } \\
\text { friends, family, and } \\
\text { work colleagues saw } \\
\text { the photos when they } \\
\text { were added to the } \\
\text { fake account. }\end{array}$ & $\begin{array}{l}\text { The victim sued for invasion of } \\
\text { privacy, negligence, IIED, NIED, } \\
\text { and false impersonation (Cal. } \\
\text { Penal Code } \S 528.5 \text { ). The jury } \\
\text { found Bruce and Rodil guilty of } \\
\text { invasion of privacy and } \\
\text { negligence, and found Rodil } \\
\text { guilty of publicly disclosing } \\
\text { private facts. The IIED, NIED and } \\
\text { impersonation claims failed. The } \\
\text { jury awarded } \$ 250,000 \text { in } \\
\text { damages. }\end{array}$ \\
\hline $\begin{array}{l}\text { Tharpe } v . \\
\text { Lawidjaja93 }\end{array}$ & $\begin{array}{l}\text { The parties entered } \\
\text { into a contract for a } \\
\text { photo shoot that } \\
\text { would help the }\end{array}$ & $\begin{array}{l}\text { The plaintiff sued for fraud, IIED, } \\
\text { tortious interference with } \\
\text { contract, and defamation. The } \\
\text { judge denied the defendant's }\end{array}$ \\
\hline
\end{tabular}

9o State v. McLellan, 154 Idaho 77, 294 P.3d 303 (Ct. App. 2013).

${ }_{91} I d$.

92 Although the case's public record contains the plaintiff's actual name, we use a "Doe" appellation consistent with her attorney's publicity of the ruling. See Karl S. Kronenberger, Firm Obtains Landmark \$250, ooo Civil Verdict in Revenge Porn Case, KRONENBERGER ROSENFELD (Feb. 19, 2014), https://www.krinternetlaw.com/news/article-detail/firmobtains-landmark-250000-civil-verdict-in-revenge-porn-case [https://perma.cc/5F28$658 \mathrm{G}]$. The key facts are allegations from Brief for Petitioner, Doe v. Bruce, No. 112 CV2333490 (Cal. App. Dep't Super. Ct. Jan. 31, 2014). See also Doe v. Bruce, No. 112CV2333490 (Cal. App. Dep’t Super. Ct. Feb. 18, 2014).

93 Tharpe v. Lawidjaja, 8 F. Supp. 3d 743 (W.D. Va. 2014). 


\begin{tabular}{|c|c|c|}
\hline Case Name & Key Facts & Outcome \\
\hline & $\begin{array}{l}\text { plaintiff's aspiring } \\
\text { modeling career. } \\
\text { Outside the } \\
\text { agreement's terms, } \\
\text { the defendant took } \\
\text { nude photos of the } \\
\text { plaintiff, but assured } \\
\text { the plaintiff that the } \\
\text { photos would not be } \\
\text { released. The parties' } \\
\text { relationship broke } \\
\text { down, and the } \\
\text { defendant posted } \\
\text { thousands of the } \\
\text { plaintiff's nude } \\
\text { photos online. }\end{array}$ & $\begin{array}{l}\text { summary judgment motion } \\
\text { because the facts sufficiently } \\
\text { alleged the defendant (1) } \\
\text { fraudulently induced the plaintiff } \\
\text { into posing nude by falsely } \\
\text { promising the photos would not } \\
\text { be revealed, and (2) interfered } \\
\text { with the defendant's profession } \\
\text { by disseminating the photos. The } \\
\text { court said the defendant's harms } \\
\text { may include the following: being } \\
\text { fired, passed over for a } \\
\text { promotion, denied a pay raise } \\
\text { and put on a leave of absence; as } \\
\text { well as emotional distress due to } \\
\text { treatment for panic attacks and } \\
\text { anxiety. The court also found that } \\
\text { a reasonable fact-finder could } \\
\text { determine that the defendant } \\
\text { defamed the plaintiff by editing } \\
\text { the photos and calling the } \\
\text { defendant a porn star. The parties } \\
\text { apparently settled the lawsuit.94 }\end{array}$ \\
\hline $\begin{array}{l}\text { Leviston } v . \\
\text { Jackson } 95\end{array}$ & $\begin{array}{l}\text { The victim made a } \\
\text { consensual sex } \\
\text { recording with } \\
\text { Murray and claimed } \\
\text { the parties agreed to } \\
\text { keep it private. } \\
\text { Murray allegedly } \\
\text { gave the recording to } \\
\text { defendant (better }\end{array}$ & $\begin{array}{l}\text { The victim sued for defamation } \\
\text { (which she later voluntarily } \\
\text { withdrew), privacy rights } \\
\text { violations and IIED. The jury } \\
\text { awarded the plaintiff } \$ 5 \text { million } \\
\text { in damages (split evenly between } \\
\text { the privacy and IIED claims), } \\
\text { plus } \$ 2 \text { million in punitive } \\
\text { damages. }{ }^{6} \text { The victim agreed to }\end{array}$ \\
\hline
\end{tabular}

94 Peter Vieth, Soccer Coach Settles Case Against Photographer, VA. LAWYERS WEEKLY (May 30, 2014), http://valawyersweekly.com/2014/05/30/soccer-coach-settles-caseagainst-photographer [https://perma.cc/UKY3-EYMZ]. The parties had additional disputes after the settlement agreement, but the case apparently has been dormant since October 2014.

95 Leviston v. Jackson, No. 102449/10 (N.Y. Sup. Ct. Dec. 3, 2013) (denying Jackson's motion for summary judgment).

96 See, e.g., Motion for Summary Judgment of Defendant, Leviston v. Jackson, No. 102449/10 (N.Y. Sup. Ct. 2015); Barbara Ross, 50 Cent Wants Judge to Lower the \$7M in Damages He Owes in Sex Tape Lawsuit, N.Y. DAILY NEWs (Jan 6, 2016), http://www.nydailynews.com/new-york/50-cent-7m-penalty-reduced-sex-tape-case- 


\begin{tabular}{|c|c|c|}
\hline Case Name & Key Facts & Outcome \\
\hline & $\begin{array}{l}\text { known as rapper } 50 \\
\text { Cent). 50 Cent had a } \\
\text { public feud with } \\
\text { Ross, who fathered a } \\
\text { child with the victim. } \\
\text { 50 Cent edited the } \\
\text { video to, among } \\
\text { other things, obscure } \\
\text { Murray's face but not } \\
\text { the victim's. 50 Cent } \\
\text { says he published a } \\
\text { video "trailer" but } \\
\text { didn't release the } \\
\text { complete edited } \\
\text { video publicly. } \\
\text { Instead, someone } \\
\text { else published the } \\
\text { full video. }\end{array}$ & $\begin{array}{l}\text { accept } \$ 6 \text { million after } 50 \text { Cent } \\
\text { declared bankruptcy. }{ }^{97} \\
\text { 50 Cent subsequently sued his } \\
\text { litigation counsel for malpractice, } \\
\text { seeking } \$ 32 \text { million in damages. } 98\end{array}$ \\
\hline $\begin{array}{l}\text { United States } v . \\
\text { Sayer } 99\end{array}$ & $\begin{array}{l}\text { The defendant and } \\
\text { victim dated. After } \\
\text { they broke up, the } \\
\text { defendant stalked } \\
\text { and harassed her. } \\
\text { Photos depicting the } \\
\text { defendant and victim } \\
\text { having sex were } \\
\text { posted to multiple } \\
\text { pornography } \\
\text { websites, and several } \\
\text { included the victim's } \\
\text { name and contact } \\
\text { info. The defendant }\end{array}$ & $\begin{array}{l}\text { The defendant was convicted of } \\
\text { cyber-stalking (18 U.S.C. } \S \\
2261 \mathrm{~A}(2)(\mathrm{A})) \text { and identity theft } \\
\text { (18 U.S.C. } \S 1028(\mathrm{a})(7)) \text {, and } \\
\text { sentenced to a statutory } \\
\text { maximum of sixty months' } \\
\text { imprisonment. The defendant } \\
\text { appealed the cyber-stalking } \\
\text { conviction on First Amendment } \\
\text { and overbreadth grounds, and } \\
\text { requested a downward sentencing } \\
\text { departure. The appeals court } \\
\text { affirmed the district court. }\end{array}$ \\
\hline
\end{tabular}

article-1.2487959 [https://perma.cc/U9AQ-LHVP]; Mary Emily O'Hara, Judge Rules 50 Cent Must Pay Revenge-Porn Victim \$7 Million, DAILY DOT (July 25, 2015, 8:32 AM), http://www.dailydot.com/lifestyle/50-cent-lawsuit-revenge-porn-victim-wins/ [https://perma.cc/8438-3FW] .

97 Stephen Singer, Judge: 50 Cent Worth \$2O Million In Assets, HARTFORD COURANT (May 18, 2016), http://www.courant.com/news/connecticut/hc-50-cent-bankruptcy-20160518story.html [https://perma.cc/EVL3-8ZPE].

98 Jackson v. Reed Smith LLP, No. 15-21233 (D. Conn. filed Jan. 27, 2017), http://pdfserver.amlaw.com/ca/JacksonSuit.pdf.

99 United States v. Sayer, 748 F.3d 425 (1st Cir. 2014). 


\begin{tabular}{|c|c|c|}
\hline Case Name & Key Facts & Outcome \\
\hline & $\begin{array}{l}\text { also posted sexually } \\
\text { explicit pictures of } \\
\text { the victim on fake } \\
\text { Facebook and } \\
\text { MySpace accounts } \\
\text { created in her name. }\end{array}$ & \\
\hline $\begin{array}{l}\text { United States } v . \\
\text { Osinger }\end{array}$ & $\begin{array}{l}\text { The defendant and } \\
\text { victim dated. After } \\
\text { their relationship } \\
\text { ended, the defendant } \\
\text { created a Facebook } \\
\text { page that displayed } \\
\text { nude photos of her, } \\
\text { and emailed } \\
\text { additional photos to } \\
\text { her work colleagues. }\end{array}$ & $\begin{array}{l}\text { The defendant was convicted of } \\
\text { cyber-stalking (18 U.S.C. } \S \\
\text { 2261A) and sentenced to } 46 \\
\text { months' imprisonment. The } \\
\text { appeals court rejected invalidity } \\
\text { and vagueness challenges to the } \\
\text { statute and rejected a downward } \\
\text { sentencing departure, thus } \\
\text { affirming the district court. }\end{array}$ \\
\hline Brown v. State ${ }^{101}$ & $\begin{array}{l}\text { The defendant and } \\
\text { victim dated. After } \\
\text { their relationship } \\
\text { ended, the defendant } \\
\text { disseminated nude } \\
\text { photos and videos to } \\
\text { the victim's Facebook } \\
\text { friends and landlord. }\end{array}$ & $\begin{array}{l}\text { The trial court issued a protective } \\
\text { order that the defendant violated. } \\
\text { The defendant pled guilty to a } \\
\text { reduced charge of Class D felony } \\
\text { stalking (Ind. Code } \S 35-45^{-10-5)} \\
\text { and was sentenced to the } \\
\text { maximum sentence of three } \\
\text { years. The appeals court affirmed. }\end{array}$ \\
\hline $\begin{array}{l}\text { People } v . \\
\text { Barber } 102\end{array}$ & $\begin{array}{l}\text { The defendant posted } \\
\text { nude photos of his } \\
\text { girlfriend to his } \\
\text { Twitter account and } \\
\text { sent the photos to the } \\
\text { girlfriend's employer } \\
\text { and sister without } \\
\text { authorization } \\
\text { (although he claims } \\
\text { the victim authorized } \\
\text { the disseminations). }\end{array}$ & $\begin{array}{l}\text { The defendant was prosecuted for } \\
\text { aggravated harassment in the } \\
\text { second degree (N.Y. Penal Law } \S \\
240.30(1)(a) \text { ), disseminating an } \\
\text { unlawful surveillance image in } \\
\text { the second degree (N.Y. Penal } \\
\text { Law } \S 250.55) \text {, and publicly } \\
\text { displaying offensive sexual } \\
\text { material (N.Y. Penal Law } \S \\
245.11(\text { a)). The court dismissed } \\
\text { all the charges. } \\
\text { The harassment charge failed } \\
\text { because the tweets were not a }\end{array}$ \\
\hline
\end{tabular}

100 United States v. Osinger, 753 F.3d 939 (9th Cir. 2014).

${ }^{101}$ Brown v. State, 15 N.E.3d 687 (Ind. Ct. App. 2014), transfer denied; Brown v. State, 17 N.E.3d 932 (Ind. Ct. App. 2014).

102 People v. Barber, 992 N.Y.S.2d 159 (N.Y. Crim. Ct. 2014). 


\begin{tabular}{|c|c|c|}
\hline Case Name & Key Facts & Outcome \\
\hline & & $\begin{array}{l}\text { communication to the victim and } \\
\text { did not encourage others to } \\
\text { contact the victim. The unlawful } \\
\text { dissemination charge failed } \\
\text { because the complaint was } \\
\text { factually insufficient. For } \\
\text { example, it did not explain how } \\
\text { the pictures were obtained. The } \\
\text { public display charge failed } \\
\text { because posting an image on } \\
\text { Twitter and sending an image to } \\
\text { individuals were private acts, not } \\
\text { a public display. Moreover, the } \\
\text { state did not sufficiently show the } \\
\text { requisite prurient interest in the } \\
\text { nude photos. }\end{array}$ \\
\hline $\begin{array}{l}\text { Keaton } v . \\
\text { Hannum }{ }^{103}\end{array}$ & $\begin{array}{l}\text { After they broke up, } \\
\text { the ex-boyfriend (a } \\
\text { lawyer) created a } \\
\text { blog about the victim } \\
\text { that included } \\
\text { sexually explicit } \\
\text { photos and sent the } \\
\text { photos to her friends } \\
\text { and family. }\end{array}$ & $\begin{array}{l}\text { The state dismissed criminal } \\
\text { charges against the ex-boyfriend } \\
\text { (without prejudice) "based on } \\
\text { personal privacy concerns raised } \\
\text { by" the victim. The ex-boyfriend } \\
\text { sued the police for allegedly } \\
\text { violating his civil rights. The } \\
\text { court dismissed his lawsuit } \\
\text { because the police had probable } \\
\text { cause to arrest him and charge } \\
\text { him with stalking. Separately, the } \\
\text { Indiana State Bar disbarred the } \\
\text { ex-boyfriend in part for his } \\
\text { conduct towards the victim. }\end{array}$ \\
\hline $\begin{array}{l}\text { United States } v . \\
\text { Elam }^{104}\end{array}$ & $\begin{array}{l}\text { The victim sent } \\
\text { intimate photos and } \\
\text { videos to her } \\
\text { boyfriend with the } \\
\text { understanding that }\end{array}$ & $\begin{array}{l}\text { Charges were filed for stalking, } \\
\text { aggravated identity theft, and } \\
\text { unauthorized access to a computer. } \\
\text { However, the government } \\
\text { dismissed the case, }{ }^{105} \text { saying it did }\end{array}$ \\
\hline
\end{tabular}

103 Keaton v. Hannum, No. 1:12-CV-00641-SEB, 2014 WL 941352 (S.D. Ind. Mar. 11, 2014); In the Matter of R. Mark Keaton, 29 N.E.3d 103 (Ind. 2015).

104 United States v. Elam, No. 2:14-cr-00368 (C.D. Cal. Jun 24, 2014).

105 Matthew Goldstein, Law Firm Founds Project to Fight 'Revenge Porn', N.Y. TIMES DEALBOOK (Jan. 29, 2015), http://dealbook.nytimes.com/2015/01/29/law-firm-foundsproject-to-fight-revenge-porn [https://perma.cc/Y35E-NM9E]. 


\begin{tabular}{|c|c|c|}
\hline Case Name & Key Facts & Outcome \\
\hline & $\begin{array}{l}\text { they would remain } \\
\text { private. After they } \\
\text { broke up, the } \\
\text { defendant allegedly } \\
\text { created a fake dating } \\
\text { profile for the victim } \\
\text { using suggestive } \\
\text { photos and } \\
\text { disseminated at least } \\
\text { one sex video to } \\
\text { multiple } \\
\text { pornography } \\
\text { websites. The } \\
\text { defendant also } \\
\text { allegedly posted } \\
\text { explicit material to } \\
\text { Tumblr, and } \\
\text { distributed videos by } \\
\text { impersonating } \\
\text { individuals in the } \\
\text { victim's social circle. } \\
\text { The defendant also } \\
\text { allegedly } \\
\text { disseminated the } \\
\text { victim's contact } \\
\text { information publicly. }\end{array}$ & $\begin{array}{l}\text { not think it could meet its burden } \\
\text { of proof at trial. }{ }^{106}\end{array}$ \\
\hline Doe v. Elam ${ }^{107}$ & $\begin{array}{l}\text { Same facts as United } \\
\text { States } v \text {. Elam. }\end{array}$ & $\begin{array}{l}\text { The victim sued for copyright } \\
\text { infringement, online } \\
\text { impersonation with intent to } \\
\text { cause harm, intrusion, IIED, } \\
\text { negligence, and NIED. } 108 \text { This } \\
\text { case was stayed pending } \\
\text { resolution of Elam's criminal } \\
\text { prosecution and remains active as } \\
\text { of July } 27,2017 \text {. }\end{array}$ \\
\hline
\end{tabular}

${ }^{106}$ Matthew Goldstein, In 'Revenge Porn' Case, Criminal Court Decision May Affect Lawsuit, N.Y. TIMES (Apr. 1, 2016), http://www.nytimes.com/2016/04/o2/business/dealbook/in-revenge-porn-casecriminal-court-decision-may-affect-lawsuit.html [https://perma.cc/Z9CW-8SKM]

107 Complaint, Doe v. Elam, No. 2:14-cv-09788-PSG-MAN (C.D. Cal. Dec. 24, 2014). $108 \mathrm{Id}$. 


\begin{tabular}{|c|c|c|}
\hline Case Name & Key Facts & Outcome \\
\hline $\begin{array}{l}\text { In re } \\
\text { Grossman }^{109}\end{array}$ & $\begin{array}{l}\text { The victim and } \\
\text { defendant created a } \\
\text { consensual sex } \\
\text { recording while } \\
\text { dating with the } \\
\text { understanding that it } \\
\text { would be kept } \\
\text { private. After they } \\
\text { broke up, the } \\
\text { defendant posted the } \\
\text { recording to a } \\
\text { pornographic } \\
\text { website. }\end{array}$ & $\begin{array}{l}\text { The victim sued for privacy } \\
\text { violations and IIED. The } \\
\text { defendant declared bankruptcy } \\
\text { and then made an offer of } \\
\text { judgment of } \$ 25, \text { ooo, which the } \\
\text { plaintiff accepted. The } \\
\text { bankruptcy court held that the } \\
\$ 25, \text { ooo may not be } \\
\text { dischargeable in bankruptcy } \\
\text { because the victim adequately } \\
\text { alleged that the defendant acted } \\
\text { maliciously/willfully. }\end{array}$ \\
\hline $\begin{array}{l}\text { United States } v \text {. } \\
\text { Kisling }^{110}\end{array}$ & $\begin{array}{l}\text { Defendant posed } \\
\text { online as a teenage } \\
\text { girl and enticed a } \\
\text { minor to send nude } \\
\text { photos of herself. The } \\
\text { defendant then } \\
\text { hacked into the } \\
\text { victim's Facebook } \\
\text { account and } \\
\text { uploaded the photos. } \\
\text { The defendant } \\
\text { repeated his actions } \\
\text { two years later when } \\
\text { he posted the photos } \\
\text { on a Facebook page } \\
\text { that he created using } \\
\text { a stolen } \\
\text { identification. }\end{array}$ & $\begin{array}{l}\text { The defendant pled guilty to } \\
\text { identity theft and distribution, } \\
\text { possession, and receipt of child } \\
\text { pornography. The defendant } \\
\text { received concurrent sentences of } \\
240 \text { months and } 180 \text { months. }\end{array}$ \\
\hline Crapps v. State ${ }^{111}$ & $\begin{array}{l}\text { The defendant logged } \\
\text { into his ex- } \\
\text { girlfriend's } \\
\text { Instagram account } \\
\text { and posted nude } \\
\text { photos of her. }\end{array}$ & $\begin{array}{l}\text { The trial court convicted the } \\
\text { defendant of willful and knowing } \\
\text { access to a computer or computer } \\
\text { system without authorization } \\
\text { (Fla. Stat. Ann. } § 815 \cdot 06(1)(a)) \text {. } \\
\text { The appeals court partially } \\
\text { reversed because the state had }\end{array}$ \\
\hline
\end{tabular}

109 In re Grossman, 538 B.R. 34 (Bankr. E.D. Cal. 2015).

110 United States v. Kisling, No. 1:14CRo157, 2015 WL 5055512 (N.D. Ohio Aug. 25, 2015).

${ }^{111}$ Crapps v. State, 180 So. 3 d 1125 (Fla. Dist. Ct. App. 2015). 


\begin{tabular}{|c|c|c|}
\hline Case Name & Key Facts & Outcome \\
\hline & & $\begin{array}{l}\text { not proved that the defendant } \\
\text { accessed a specific computer or } \\
\text { computer system. The appeals } \\
\text { court remanded to give the state } \\
\text { the opportunity to establish the } \\
\text { crime's elements. We did not find } \\
\text { subsequent reported proceedings. }\end{array}$ \\
\hline State v. Yarber 112 & $\begin{array}{l}\text { The defendant and } \\
\text { victim dated on-and- } \\
\text { off. During a period } \\
\text { of reconciliation, the } \\
\text { victim sent nude } \\
\text { images of herself to } \\
\text { Yarber. After their } \\
\text { relationship ended, } \\
\text { the defendant posted } \\
\text { nude photos to } \\
\text { Craigslist to solicit } \\
\text { sex, putatively in the } \\
\text { victim's name. These } \\
\text { postings caused } \\
\text { strangers seeking sex } \\
\text { to contact the victim. }\end{array}$ & $\begin{array}{l}\text { The defendant was convicted of } \\
\text { video voyeurism (Idaho Code } \\
\text { Ann. } § 18-6609(2))^{113} \text { and } \\
\text { sentenced to fifteen years, with a } \\
\text { minimum confinement of seven } \\
\text { years. The appeals court affirmed, } \\
\text { holding that the defendant had } \\
\text { the requisite scienter because he } \\
\text { knew the victim created the } \\
\text { images to arouse the defendant } \\
\text { sexually. }\end{array}$ \\
\hline $\begin{array}{l}\text { Patel v. } \\
\text { Hussain }\end{array}$ & $\begin{array}{l}\text { While they dated, the } \\
\text { victim shared explicit } \\
\text { photos with the } \\
\text { defendant, and the } \\
\text { defendant recorded } \\
\text { sexual videos without } \\
\text { her consent. After } \\
\text { they broke up, the } \\
\text { defendant harassed } \\
\text { the plaintiff, } \\
\text { including emailing }\end{array}$ & $\begin{array}{l}\text { A jury ruled in the victim's favor } \\
\text { on claims for IIED, intrusion on } \\
\text { seclusion, public disclosure of } \\
\text { private facts, and defamation; } \\
\text { and awarded her } \$ 500, \text { ooo for } \\
\text { past and future mental anguish } \\
\text { damages, past and future } \\
\text { reputation damages, and } \\
\text { exemplary damages. } \\
\text { The appeals court reversed the } \\
\text { defamation ruling and the IIED }\end{array}$ \\
\hline
\end{tabular}

${ }^{112}$ State v. Yarber, No. 42418, 2015 WL 9259888 (Idaho Ct. App. Dec. 18, 2015).

113 Despite the crime's name, it applies to the intentional dissemination of intimate images without consent.

114 Patel v. Hussain, 485 S.W.3d 153 (Tex. App. 2016). 


\begin{tabular}{|c|c|c|}
\hline Case Name & Key Facts & Outcome \\
\hline & $\begin{array}{l}\text { the victim's photos to } \\
\text { her mother and } \\
\text { posting the videos to } \\
\text { a pornography } \\
\text { website. The victim } \\
\text { said the videos } \\
\text { harmed her standing } \\
\text { in the Muslim } \\
\text { community. }\end{array}$ & $\begin{array}{l}\text { damages award. This reduced the } \\
\text { damage award to } \$ 345,000 .{ }^{115}\end{array}$ \\
\hline $\begin{array}{l}\text { Bollea } v . \\
\text { Gawker }\end{array}$ & $\begin{array}{l}\text { The victim, known as } \\
\text { Hulk Hogan, had sex } \\
\text { with Clem, his } \\
\text { friend's wife. }{ }^{117} \text { The } \\
\text { victim claims he did } \\
\text { not know he was } \\
\text { being recorded.118 } \\
\text { The recording made } \\
\text { its way to a Gawker }\end{array}$ & $\begin{array}{l}\text { The victim first sued for copyright } \\
\text { infringement but was denied a } \\
\text { TRO and later dismissed the } \\
\text { federal case. }{ }^{120} \text { The victim refiled } \\
\text { in state court, alleging privacy } \\
\text { violations (public disclosure of } \\
\text { private facts and intrusion into } \\
\text { seclusion), publicity rights } \\
\text { violations, IIED and Florida's }\end{array}$ \\
\hline
\end{tabular}

115 Id. at 184; Michelle Casady, Texas Appeals Court Reduces Revenge Porn Damages, LAW36o (Jan. 21, 2016), http://www.law36o.com/articles/749307/texas-appeals-courtreduces-revenge-porn-damages [https://perma.cc/JT6M-GPYY].

${ }_{116}$ See Bollea v. Gawker Media, LLC, 913 F. Supp. $2 d 1325$ (M.D. Fla. 2012). See also, Eriq Gardner, Hulk Hogan, Gawker Make Opening Statements in Sex Tape Trial, HollywOOD REPORTER (Mar. 7, 2016), http://www.hollywoodreporter.com/thr-esq/hulk-hogangawker-make-opening-873097 [https://perma.cc/N4ST-WKEF]; Eriq Gardner, Hulk Hogan Testifies That Gawker's Sex Tape "Turned My World Upside Down," HOLLYWOOD REPORTER (Mar. 7, 2016), http://www.hollywoodreporter.com/thr-esq/hulk-hogantestifies-gawkers-sex-87316o [https://perma.cc/9H85-6ZAL]; Eriq Gardner, Hulk Hogan Grilled About Sex-Filled TMZ, Howard Stern Interviews at Gawker Trial, HOLLYWOOD REPORTER (Mar. 8, 2016), http://www.hollywoodreporter.com/thr-esq/hulk-hogangrilled-sex-filled-873435 [https://perma.cc/GF6W-2Z88]; Eriq Gardner, At Trial, ‘Gawker' Staffers Explain Hulk Hogan Sex Tape Post, HOLLYWOOD REPORTER (Mar. 9, 2016), http://www.hollywoodreporter.com/thr-esq/at-trial-gawker-staffers-explain873817 [https://perma.cc/PH4N-ESK6]; Eriq Gardner, Hulk Hogan Offers up Expert Testifying to Gawker's Increased Value from Sex Tape, HOLLYWOOD REPORTER (Mar. 11, 2016), http://www.hollywoodreporter.com/thr-esq/hulk-hogan-offers-up-expert-874531 [https://perma.cc/CK5Z-DW9E]; Eriq Gardner, Judge Upholds Hulk Hogan's \$14O Million Trial Victory Against Gawker, HOLLYWOOD REPORTER (May 25, 2016), http://www.hollywoodreporter.com/thr-esq/judge-upholds-hulk-hogans-140-897301 [https://perma.cc/8PFU-RL3K].

117 Tom Kludt, Why Hulk Hogan Settles for \$5,ooo with the Man Who Made His Sex Tape, CNN MONEY (Mar. 12, 2016), http://money.cnn.com/2016/o3/12/media/hulk-hogangawker-settlement/ [https://perma.cc/7HCH-YXT2].

${ }^{118}$ Bollea v. Gawker Media, LLC, 913 F. Supp. 2 d 1325 (M.D. Fla. 2012). 


\begin{tabular}{|c|c|c|}
\hline Case Name & Key Facts & Outcome \\
\hline & $\begin{array}{l}\text { editor, who } \\
\text { published two } \\
\text { minutes of the thirty- } \\
\text { minute recording, } \\
\text { including ten seconds } \\
\text { of sexual activity.119 }\end{array}$ & $\begin{array}{l}\text { Security of Communications } \\
\text { Act. }{ }^{121} \text { A jury ruled for the victim } \\
\text { on all claims and awarded } \$ 115 \\
\text { million in compensatory damages } \\
\text { and } \$ 25 \text { million in punitive } \\
\text { damages. }{ }^{122} \text { The jury's damage } \\
\text { award contributed to Gawker } \\
\text { declaring Chapter } 11 \\
\text { bankruptcy } 123 \text { and its subsequent } \\
\text { sale to Univision. } .^{124} \text { The parties } \\
\text { settled for } \$ 31 \text { million plus a } \\
\text { share of the company's sales } \\
\text { proceeds. }{ }^{125}\end{array}$ \\
\hline
\end{tabular}

${ }^{120}$ Bollea, 913 F. Supp. $2 \mathrm{~d}$ at 1325.

119 Id. at 1325; Gawker, Hulk Hogan in Settlement Talks Over Privacy Case: WSJ, REUTERS (Aug. 7, 2016), http://finance.yahoo.com/news/gawker-hulk-hogan-settlementtalks-over-privacy-case-023354185--finance.html. [https://perma.cc/33Z4-R8Y2]; Lloyd Grove, A.J. Daulerio Doesn't Regret Child Sex Quip at Hogan-Gawker Trial, THE DAILY BEAST (Mar. 23, 2015), http://www.thedailybeast.com/articles/2016/03/23/a-j-dauleriodoesn-t-regret-child-sex-quip-at-hogan-gawker-trial.html [https://perma.cc/5E5GNQG5]; Nathan McAlone, Everything You Need to Know About the Hulk Hogan Sex-Tape Lawsuit That Could Cost Gawker Over \$115 Million, BUSINESS INSIDER (Mar. 20, 2016), http://www.businessinsider.com/hulk-hogan-versus-gawker-lawsuit-explained-2016-3 [https://perma.cc/7G9W-J8Z9].

${ }^{121}$ See First Amended Complaint and Demand for Jury Trial, Bollea v. Gawker, No. 12012447-CI-011 (Fla. 6th Cir. Ct. Dec. 28, 2012).

122 Steven Perlberg, Hulk Hogan Awarded Additional \$25 Million in Gawker Sex-Tape Case, WALL ST. J. (Mar. 21, 2016), http://www.wsj.com/articles/hulk-hogan-awardedadditional-25-million-in-gawker-case-1458598102 [https://perma.cc/FZV8-YVG8].

123 Lloyd Grove, Gawker Declared Bankruptcy to Stop Hulk Hogan from Taking It Over, DAILY BEAST (June 10, 2016),

http://www.thedailybeast.com/articles/2016/o6/10/gawker-declared-bankruptcy-tostop-hulk-hogan-from-taking-it-over.html [https://perma.cc/HMB4-CPH6]; Peter Sterne, Gawker Media Files for Bankruptcy, POLITICO (June 10, 2016),

http://www.politico.com/media/story/2016/o6/gawker-files-for-bankruptcy-to-protectassets-from-hogan-004593 [https://perma.cc/M6HU-TAEB].

124 Lukas I. Alpert \& Tom Corrigan, Gawker.com will Shut Down Next Week as Univision Acquires Rest of Company, WALL ST. J. (Aug. 18, 2016),

http://www.wsj.com/articles/univision-plans-to-shut-down-gawker-com-1471539451

[https://perma.cc/A96P-XARF].

125 Merritt Kennedy, Hulk Hogan Reaches Settlement With Gawker Worth Over \$31

Million, NPR (Nov. 2, 2016), http://www.npr.org/sections/thetwo- 


\begin{tabular}{|c|c|c|}
\hline Case Name & Key Facts & Outcome \\
\hline & & $\begin{array}{l}\text { During the trial, it was revealed } \\
\text { that Silicon Valley billionaire } \\
\text { Peter Thiel funded Bollea's } \\
\text { lawsuit (and other lawsuits } \\
\text { against Gawker) as retribution for } \\
\text { Gawker's outing of Thiel in } \\
\text { 2007.126 }\end{array}$ \\
\hline $\begin{array}{l}\text { Hoewischer } v \text {. } \\
\text { White (In re } \\
\text { White) }{ }^{127}\end{array}$ & $\begin{array}{l}\text { The defendant posted } \\
\text { nude photos of his } \\
\text { ex-girlfriend on a } \\
\text { revenge porn website } \\
\text { along with her } \\
\text { contact information. } \\
\text { The victim received } \\
\text { comments about her } \\
\text { body and } \\
\text { solicitations for sex, } \\
\text { which made her } \\
\text { depressed, shy, and } \\
\text { fearful for her safety. }\end{array}$ & $\begin{array}{l}\text { The victim's IIED claim failed } \\
\text { because it was not clear that the } \\
\text { emotional distress was serious } \\
\text { and of such a nature that no } \\
\text { reasonable person could be } \\
\text { expected to endure it. However, } \\
\text { the court granted a default } \\
\text { judgment for the privacy invasion } \\
\text { claim and awarded } \$ 50,000 \\
\text { compensatory damages, } \\
\$ 100, \text { ooo punitive damages and } \\
\$ 1,123 \text { for attorney fees. } \\
\text { Subsequently, the defendant filed } \\
\text { for bankruptcy. The Bankruptcy } \\
\text { Court held the judgment was not } \\
\text { dischargeable because the } \\
\text { defendant's conduct was willful } \\
\text { and malicious. }\end{array}$ \\
\hline In re J.O.128 & $\begin{array}{l}\text { The defendant, a } \\
\text { minor, received } \\
\text { sexually explicit } \\
\text { images from two high } \\
\text { school classmates. } \\
\text { Instead of deleting } \\
\text { the images as they } \\
\text { requested, the }\end{array}$ & $\begin{array}{l}\text { The defendant was found to have } \\
\text { violated Cal. Penal Code } \S \\
311.11 \text { (a) (possessing material } \\
\text { depicting a minor engaged in } \\
\text { sexual conduct) and Cal. Penal } \\
\text { Code } \S 311.3 \text { (misdemeanor } \\
\text { sexual exploitation of a child). } \\
\text { The juvenile court declared the }\end{array}$ \\
\hline
\end{tabular}

way/2016/11/02/500389355/hulk-hogan-reaches-settlement-with-gawker-worth-over-31million [https://perma.cc/5V5X-LT4Y].

${ }^{126}$ Andrew Ross Sorkin, Peter Thiel, Tech Billionaire, Reveals Secret War With Gawker, N.Y. TiMES (May 25, 2016), www.nytimes.com/2016/05/26/business/dealbook/peterthiel-tech-billionaire-reveals-secret-war-with-gawker.html [http://perma.cc/26BWKESV].

127 Hoewischer v. White (In re White), 551 B.R. 814 (Bankr. S.D. Ohio 2016).

${ }_{128}$ In re J.O., No. A145223, 2016 Cal. App. Unpub. LEXIS 1620 (Mar. 4, 2016). 


\begin{tabular}{|c|c|c|}
\hline Case Name & Key Facts & Outcome \\
\hline & $\begin{array}{l}\text { defendant circulated } \\
\text { the images to others. }\end{array}$ & $\begin{array}{l}\text { defendant a ward of the court, } \\
\text { committed him to a county } \\
\text { institution for six months (plus } \\
\text { an additional ninety-day } \\
\text { conditional release period), and } \\
\text { imposed probation conditions } \\
\text { that included having no contact } \\
\text { with the victims or their families. } \\
\text { The appeals court slightly } \\
\text { modified the no-contact } \\
\text { probation condition and } \\
\text { otherwise affirmed. }\end{array}$ \\
\hline L.Z.v. K.Q. ${ }^{129}$ & $\begin{array}{l}\text { The defendant and } \\
\text { victim dated. After } \\
\text { they broke up, the } \\
\text { defendant logged } \\
\text { into the victim's } \\
\text { Snapchat account } \\
\text { and disseminated a } \\
\text { sexually explicit } \\
\text { video of her to some } \\
\text { of her Snapchat } \\
\text { contacts. }\end{array}$ & $\begin{array}{l}\text { The judge issued a final } \\
\text { restraining order (FRO) against } \\
\text { defendant. The appeals court } \\
\text { affirmed, holding that a single act } \\
\text { can constitute domestic violence } \\
\text { for FRO purposes and that } \\
\text { harassment can include sending } \\
\text { images of plaintiff engaged in } \\
\text { private sexual acts. }\end{array}$ \\
\hline $\begin{array}{l}\text { United States } v \text {. } \\
\text { Fitzhugh }{ }^{130}\end{array}$ & $\begin{array}{l}\text { Defendant allegedly } \\
\text { used a fake alias to } \\
\text { communicate with } \\
\text { the minor victim via } \\
\text { a messaging app; } \\
\text { convinced her to } \\
\text { send him nude } \\
\text { photos of herself; and } \\
\text { then posted the } \\
\text { photos to a foreign } \\
\text { website. }\end{array}$ & $\begin{array}{l}\text { Defendant was charged with } \\
\text { producing child pornography ( } 18 \\
\text { U.S.C. } \S 2255 \text { ), online enticement } \\
\text { and coercion of a minor ( } 18 \\
\text { U.S.C. } \S 2422(b) \text { ), and } \\
\text { receipt/distribution of child } \\
\text { pornography (18 U.S.C. } \S \\
2252 A(a)(2)) \text {. The judge } \\
\text { approved the defendant's } \\
\text { detention. }\end{array}$ \\
\hline State v. Ravi ${ }^{131}$ & $\begin{array}{l}\text { Defendant used his } \\
\text { laptop's webcam to } \\
\text { surreptitiously }\end{array}$ & $\begin{array}{l}\text { A jury convicted the defendant of } \\
\text { invasion of privacy, bias } \\
\text { intimidation, attempted invasion }\end{array}$ \\
\hline
\end{tabular}

${ }^{129}$ L.Z. v. K.Q., No. A-4776-14T3, 2016 N.J. Super. LEXIS 1653 (App. Div. July 18, 2016).

${ }_{130}$ United States v. Fitzhugh, No. 16-mj-30364, 2016 U.S. Dist. LEXIS 122953 (E.D. Mich. Sept. 12, 2016).

${ }^{131}$ State v. Ravi, 147 A.3d 455 (N.J. Super. Ct. App. Div. 2016). 


\begin{tabular}{|c|c|c|}
\hline Case Name & Key Facts & Outcome \\
\hline & $\begin{array}{l}\text { broadcast (to several } \\
\text { other people) his } \\
\text { roommate having } \\
\text { sexual relations with } \\
\text { another man on } \\
\text { multiple occasions. }\end{array}$ & $\begin{array}{l}\text { of privacy, tampering with } \\
\text { physical evidence, hindering } \\
\text { apprehension or prosecution, } \\
\text { witness tampering, and } \\
\text { tampering with physical evidence } \\
\text { under New Jersey's criminal code } \\
\text { (N.J.S.A. \& 2C:14). The trial court } \\
\text { sentenced the defendant to three } \\
\text { years of probation, conditioned } \\
\text { upon serving thirty days at a } \\
\text { correctional center, along with } \\
\text { community service, counseling, } \\
\text { and paying an assessment of } \\
\$ 10, \text { ooo. } \\
\text { On appeal, the court vacated the } \\
\text { charges of bias intimidation and } \\
\text { hindering apprehension. The } \\
\text { remaining charges were tainted } \\
\text { by improper evidence, so the } \\
\text { appeals court remanded for a } \\
\text { retrial. }\end{array}$ \\
\hline $\begin{array}{l}\text { Somerville v. } \\
\text { White }^{132}\end{array}$ & $\begin{array}{l}\text { An ex-boyfriend sued } \\
\text { the victim over an } \\
\text { alleged debt. The } \\
\text { victim } \\
\text { counterclaimed that } \\
\text { the ex-boyfriend } \\
\text { harassed and } \\
\text { threatened her to } \\
\text { coerce payment. She } \\
\text { said the ex-boyfriend } \\
\text { accessed her email } \\
\text { and forwarded } \\
\text { sexually explicit } \\
\text { photos to her email } \\
\text { contacts and } \\
\text { uploaded the photos } \\
\text { to her social media } \\
\text { account. }\end{array}$ & $\begin{array}{l}\text { The court awarded the victim } \\
\$ 500 \text { compensatory damages and } \\
\$ 15, \text { ooo punitive damages } \\
\text { pursuant to Georgia's revenge } \\
\text { porn law (Ga. Code Ann. } \$ 16-11- \\
90) .133 \text { The appeals court } \\
\text { reversed the damages award } \\
\text { because the penal statute did not } \\
\text { support a civil cause of action. }\end{array}$ \\
\hline
\end{tabular}

${ }^{132}$ Somerville v. White, 787 S.E.2d 350 (Ga. Ct. App. 2016).

133 GA. CODE ANN. § 16-11-90 (2014) (criminalizing the transmission of photography or video depicting nudity or sexually explicit conduct of an adult without his or her consent). 


\begin{tabular}{|c|c|c|}
\hline Case Name & Key Facts & Outcome \\
\hline $\begin{array}{l}\text { Morehead } v . \\
\text { Commonwealth } \\
134\end{array}$ & $\begin{array}{l}\text { The victim's ex- } \\
\text { husband posted } \\
\text { intimate images of } \\
\text { the victim on a } \\
\text { pornography website. } \\
\text { The ex-husband then } \\
\text { emailed a link to the } \\
\text { victim and further } \\
\text { posted the link on the } \\
\text { victim's employer's } \\
\text { Facebook page. }\end{array}$ & $\begin{array}{l}\text { The trial court convicted the } \\
\text { defendant of unlawful } \\
\text { dissemination of images of } \\
\text { another person (Va. Code Ann. } \S \\
\text { 18.2-386.2). The appeals court } \\
\text { affirmed. }\end{array}$ \\
\hline $\begin{array}{l}\text { Barber } v . \\
\text { Vance }^{135}\end{array}$ & $\begin{array}{l}\text { Barber and Vance } \\
\text { had an intimate } \\
\text { relationship. They } \\
\text { consensually made } \\
\text { pornographic videos. } \\
\text { After they broke up, } \\
\text { Barber uploaded } \\
\text { several videos to } \\
\text { adult websites. He } \\
\text { claimed he produced } \\
\text { the videos with } \\
\text { Vance for } \\
\text { commercial } \\
\text { purposes. }\end{array}$ & $\begin{array}{l}\text { A state prosecutor charged } \\
\text { Barber with violating Oregon's } \\
\text { new revenge porn crime (Or. Rev. } \\
\text { Stat. § 163.472). Barber sought a } \\
\text { TRO against the prosecution, } \\
\text { claiming it violated his First } \\
\text { Amendment and copyright } \\
\text { ownership rights. The court } \\
\text { rejected the request on Younger } \\
\text { abstention grounds. At trial, } \\
\text { Barber was convicted of five } \\
\text { counts and sentenced to six } \\
\text { months in jail plus five years of } \\
\text { probation.136 }\end{array}$ \\
\hline
\end{tabular}

134 Morehead v. Commonwealth, 784 S.E.2d 301 (Va. Ct. App. 2016).

135 Barber v. Vance, No. 3:16-CV-2105-AC, 2016 WL 6647936 (D. Or. Nov. 9, 2016).

136 Press Release, Washington County (Or.) Sheriff's Office, Man First to be Prosecuted Under New Oregon Law (Dec. 1, 2016), http://www.co.washington.or.us/News/SONews/upload/PR161201-Man-First-to-beProsecuted-Under-New-Oregon-Law.pdf [https://perma.cc/64AN-97GW]. 


\section{APPENDIX C}

\section{THREATENED DistriBUTION}

\begin{tabular}{|c|c|c|}
\hline Case Name & Key Facts & Outcome \\
\hline Dula v. State 137 & $\begin{array}{l}\text { While they dated, the } \\
\text { victim posed for } \\
\text { explicit photos for the } \\
\text { defendant. The } \\
\text { defendant then forced } \\
\text { the victim to engage in } \\
\text { prostitution by } \\
\text { threatening to } \\
\text { disseminate the photos } \\
\text { to the victim's } \\
\text { contacts. }\end{array}$ & $\begin{array}{l}\text { The defendant was convicted of } \\
\text { compelling prostitution under } \\
\text { Tex. Penal Code } \S 43.05 \text { and } \\
\text { sentenced to ten years in prison } \\
\text { plus a } \$ 10,000 \text { fine. The appeals } \\
\text { court affirmed. }\end{array}$ \\
\hline $\begin{array}{l}\text { United States } \\
v . \text { Hutson }{ }^{138}\end{array}$ & $\begin{array}{l}\text { Defendant sent ex- } \\
\text { girlfriend a letter } \\
\text { demanding } \$ 10, \text { ooo to } \\
\text { satisfy an alleged } \\
\text { "debt" owed to him. He } \\
\text { threatened to send } \\
\text { explicit photos to her } \\
\text { parents, relatives, and } \\
\text { associates if she did } \\
\text { not pay. }\end{array}$ & $\begin{array}{l}\text { Defendant was convicted of } \\
\text { extortion under } 18 \text { U.S.C. } \S 876 \text {. } \\
\text { The appeals court affirmed. }\end{array}$ \\
\hline $\begin{array}{l}\text { Vafaie } v . \\
\text { Owens }{ }^{139}\end{array}$ & $\begin{array}{l}\text { The parties had } \\
\text { business and personal } \\
\text { relationships. To } \\
\text { resolve a debt dispute, } \\
\text { defendant threatened } \\
\text { to disseminate sexually } \\
\text { explicit photos. }\end{array}$ & $\begin{array}{l}\text { Lower court granted summary } \\
\text { judgment to the victim on } \\
\text { negligence per se, extortion, } \\
\text { assault, malicious harassment, } \\
\text { and civil conspiracy claims. The } \\
\text { jury found for defendant on } \\
\text { outrageous conduct and IIED } \\
\text { claims. The appeals court } \\
\text { reversed and remanded on } \\
\text { outrageous conduct, IIED and } \\
\text { civil conspiracy claims and }\end{array}$ \\
\hline
\end{tabular}

137 Dula v. State, 679 S.W.2d 601 (Tex. App. 1984).

${ }^{138}$ United States v. Hutson, 843 F.2d 1232 (9th Cir. 1988).

139 Vafaie v. Owens, C. A. No. 01A01-9510-CV-00472, 1996 Tenn. App. LEXIS 557 (Sept. 6, 1996). 


\begin{tabular}{|c|c|c|}
\hline Case Name & Key Facts & Outcome \\
\hline & & affirmed the rest. \\
\hline $\begin{array}{l}\text { Boschette v. } \\
\text { Bach }^{140}\end{array}$ & $\begin{array}{l}\text { Defendant stole } \\
\text { explicit videotapes of } \\
\text { the plaintiffs' son and } \\
\text { threatened to publicize } \\
\text { the videos if the } \\
\text { plaintiffs did not pay } \\
\text { the defendant. }\end{array}$ & $\begin{array}{l}\text { Plaintiffs sued for extortion } \\
\text { under Puerto Rico Laws } \\
\text { Annotated ( } 33 \text { P.R. Laws Ann. § } \\
\text { 4828), but the case was } \\
\text { dismissed because the criminal } \\
\text { code did not create a civil cause } \\
\text { of action. } \\
\text { The defendant counterclaimed } \\
\text { for malicious prosecution and } \\
\text { abuse of process, but this was } \\
\text { dismissed because criminal } \\
\text { proceedings had not been } \\
\text { brought against him. }\end{array}$ \\
\hline D.C.v.F.R. ${ }^{141}$ & $\begin{array}{l}\text { The parties dated. The } \\
\text { defendant persuaded } \\
\text { the victim to pose for } \\
\text { explicit photos. The } \\
\text { defendant then } \\
\text { threatened to send the } \\
\text { photos to the plaintiff's } \\
\text { parents if she did not } \\
\text { agree to create } \\
\text { additional photos. The } \\
\text { defendant also } \\
\text { harassed the plaintiff. }\end{array}$ & $\begin{array}{l}\text { The court found the defendant } \\
\text { violated New Jersey Statutes } \\
\text { Annotated (NJSA) § 2C:12-10 } \\
\text { (stalking) and NJSA } § 2 \mathrm{C}: 33-4 \\
\text { (harassment). The court } \\
\text { awarded } \$ 14,891 \text { compensatory } \\
\text { damages and attorneys' fees } \\
\text { plus } \$ 5,875 \text { punitive damages. } \\
\text { The court also issued a } \\
\text { restraining order. } \\
\text { The appeals court affirmed the } \\
\text { findings but vacated and } \\
\text { remanded the punitive damages } \\
\text { and modified the restraining } \\
\text { order. We could not determine } \\
\text { what happened on remand. }\end{array}$ \\
\hline $\begin{array}{l}\text { Peoplev. } \\
\text { Kuhl }{ }^{142}\end{array}$ & $\begin{array}{l}\text { Christina Hakes and } \\
\text { the victim dated. } \\
\text { Hakes thought the } \\
\text { victim gave her a } \\
\text { venereal disease, so } \\
\text { she took videos of } \\
\text { them having sex from }\end{array}$ & $\begin{array}{l}\text { Hakes and Kuhl were convicted } \\
\text { of extortion under Michigan } \\
\text { Compiled Laws (MCL) } \S \\
750.213 \text { and Michigan Statutes } \\
\text { Annotated (MSA) } \S 28.410 \text { and } \\
\text { conspiracy to commit extortion } \\
\text { under MCL } \S 750.157 \text { a and MSA }\end{array}$ \\
\hline
\end{tabular}

${ }^{140}$ Boschette v. Bach, 916 F. Supp. 91 (D. P.R. 1996); Boschette v. Bach, 925 F. Supp. 100 (D. P.R. 1996).

${ }^{141}$ D.C. v. F.R., 670 A.2d 51 (N.J. Super. Ct. App. Div. 1996).

142 People v. Kuhl, No. 203979, 1999 Mich. App. LEXIS 2257 (Dec. 28, 1999). 


\begin{tabular}{|c|c|c|}
\hline Case Name & Key Facts & Outcome \\
\hline & $\begin{array}{l}\text { the victim's home } \\
\text { without permission. } \\
\text { Hakes gave the videos } \\
\text { to Scott Kuhl, who } \\
\text { created a fourteen- } \\
\text { minute compilation. } \\
\text { Hakes then threatened } \\
\text { to share the } \\
\text { compilation with the } \\
\text { victim's family } \\
\text { members and political } \\
\text { colleagues if the victim } \\
\text { did not provide her } \\
\text { with health insurance } \\
\text { coverage, } \$ 100,000, \\
\text { and more. }\end{array}$ & $\begin{array}{l}\S 28.354(1) \text {. Kuhl was sentenced } \\
\text { to } 180 \text { days in jail and two years } \\
\text { of probation. We were not able } \\
\text { to determine Hakes' sentence. }\end{array}$ \\
\hline $\begin{array}{l}\text { Jersevic v. } \\
\text { Kuhl } 143\end{array}$ & $\begin{array}{l}\text { Same facts as People } v . \\
\text { Kuhl. }\end{array}$ & $\begin{array}{l}\text { The victim sued Carol Kuhl in } \\
\text { state court for } \\
\text { extortion/blackmail/threats and } \\
\text { public disclosure of private } \\
\text { facts, and conversion. The trial } \\
\text { court granted summary } \\
\text { disposition to the defendant. } \\
\text { The appellate court reversed } \\
\text { and remanded. We could not } \\
\text { determine what happened on } \\
\text { remand. } \\
\text { The court dismissed a federal } \\
\text { lawsuit against Scott Kuhl for } \\
\text { civil RICO. }\end{array}$ \\
\hline $\begin{array}{l}\text { Prezioso } v . \\
\text { Thomas }^{144}\end{array}$ & $\begin{array}{l}\text { Hardy and Thomas } \\
\text { dated. During their } \\
\text { relationship, Thomas } \\
\text { took intimate photos of } \\
\text { Hardy. Hardy and } \\
\text { Thomas broke up. }\end{array}$ & $\begin{array}{l}\text { The plaintiff sued for IIED and } \\
\text { invasion of privacy. The court } \\
\text { ruled for the plaintiff on the } \\
\text { IIED claim and awarded } \\
\$ 300,000 \text { compensatory } \\
\text { damages and } \$ 125,000 \text { punitive }\end{array}$ \\
\hline
\end{tabular}

143 Jersevic v. Kuhl, CASE NO. oo-CV-10113-BC, 2000 U.S. Dist. LEXIS 21760 (E.D. Mich. Sept. 22, 2000); Jersevic v. Kuhl, No. 238808, 2003 WL 1558207 (Mich. Ct. App. Mar. 25, 2003).

${ }_{144}$ In re Thomas, 211 B.R. 838 (Bankr. D. S.C. 1997); In re Thomas, 254 B.R. 879 (D. S.C. 1999); Prezioso v. Thomas, No. 99-1675, 2000 U.S. App. LEXIS 7740 (4th Cir. Apr. 25, 2000). 


\begin{tabular}{|c|c|c|}
\hline Case Name & Key Facts & Outcome \\
\hline & $\begin{array}{l}\text { Later, Prezioso and } \\
\text { Hardy got engaged. } \\
\text { Thomas sent Prezioso } \\
\text { explicit photos of } \\
\text { Hardy and demanded } \\
\text { payment to keep the } \\
\text { photos private. }\end{array}$ & $\begin{array}{l}\text { damages. } \\
\text { The appeals court affirmed the } \\
\text { compensatory damages but } \\
\text { certified a question about the } \\
\text { punitive damages to the South } \\
\text { Carolina Supreme Court. The } \\
\text { parties then voluntarily } \\
\text { dismissed the case. }\end{array}$ \\
\hline $\begin{array}{l}\text { Christman } \\
\text { Hubbard } v \text {. } \\
\text { Azzara }^{145}\end{array}$ & $\begin{array}{l}\text { While dating, the } \\
\text { parties created } \\
\text { consensual sex } \\
\text { recordings. After they } \\
\text { broke up, a court } \\
\text { ordered the ex- } \\
\text { boyfriend to destroy all } \\
\text { copies of the } \\
\text { recordings. The ex- } \\
\text { boyfriend registered a } \\
\text { domain name using } \\
\text { the victim's name, } \\
\text { created a website, } \\
\text { described sexually } \\
\text { explicit videos that } \\
\text { were coming, and } \\
\text { promised to promote } \\
\text { them widely. He also } \\
\text { told the victim's } \\
\text { husband about the } \\
\text { website and his plans. }\end{array}$ & $\begin{array}{l}\text { Based on the victim's invasion } \\
\text { of privacy claim, the lower court } \\
\text { enjoined the ex-boyfriend from } \\
\text { disseminating the recordings. } \\
\text { Subsequent proceedings did not } \\
\text { disturb the injunction. }\end{array}$ \\
\hline $\begin{array}{l}\text { Azzara } v . \\
\text { United States }^{146}\end{array}$ & $\begin{array}{l}\text { This involves the same } \\
\text { facts as the Christman } \\
\text { Hubbard case above. } \\
\text { The defendant wrote a } \\
\text { letter to his ex- } \\
\text { girlfriend's father } \\
\text { demanding } \$ 3 \text { million } \\
\text { or he would }\end{array}$ & $\begin{array}{l}\text { The defendant was convicted of } \\
\text { mailing threatening } \\
\text { communications (18 U.S.C. } \S \\
876 \text { ) and extortion per the } \\
\text { Hobbs Act (10 U.S.C. } \S 1951 \text { ). } \\
\text { He was sentenced to } 168 \\
\text { months' imprisonment, three } \\
\text { years of supervised release, and }\end{array}$ \\
\hline
\end{tabular}

145 Hubbard v. Azzara, No. 8:01-cv-1154-T-24 EAJ, 2008 WL 2782828 (M.D. Fla. July 16, 2008). Permanent injunction issued September 20, 2002 and filed April 3, 2003.

146 United States v. Azzara, No. 02-1739, 2003 WL 193738 (2d Cir. Jan. 29, 2003); United States v. Azzara, No. 04-0809-CR, 2005 WL 1331273 (2d Cir. June 6, 2005); Azzara v. United States, 2011 U.S. Dist. LEXIS 122689 (S.D.N.Y. Oct. 20, 2011). 


\begin{tabular}{|c|c|c|}
\hline Case Name & Key Facts & Outcome \\
\hline & $\begin{array}{l}\text { disseminate a sexually } \\
\text { explicit video of her. }\end{array}$ & $\begin{array}{l}\text { a } \$ 300 \text { special assessment. On } \\
\text { appeal, the Second Circuit } \\
\text { affirmed the conviction, but } \\
\text { remanded for resentencing. The } \\
\text { district court reiterated its } \\
\text { original sentence, which the } \\
\text { Second Circuit then affirmed. }\end{array}$ \\
\hline $\begin{array}{l}\text { Farrell } v . \\
\text { Narain }^{147}\end{array}$ & $\begin{array}{l}\text { The parties made a } \\
\text { videotape of them } \\
\text { having sex with the } \\
\text { alleged understanding } \\
\text { that both parties would } \\
\text { own the tape and } \\
\text { would keep it private. } \\
\text { Narain then allegedly } \\
\text { worked with other co- } \\
\text { defendants to } \\
\text { commercially exploit } \\
\text { the video. }\end{array}$ & $\begin{array}{l}\text { The victim sued for breach of } \\
\text { contract, invasion of privacy, } \\
\text { violation of California's } \\
\text { common law and statutory } \\
\text { rights of publicity (Civil Code } \S \\
\text { 3344), and unfair competition } \\
\text { and unfair business practices. } \\
\text { The case apparently settled. }\end{array}$ \\
\hline $\begin{array}{l}\text { People v. } \\
\text { Wood }^{148}\end{array}$ & $\begin{array}{l}\text { The victim hired the } \\
\text { defendant to take } \\
\text { intimate photos of her. } \\
\text { During the photo } \\
\text { shoot, the victim } \\
\text { claimed that the } \\
\text { defendant sexually } \\
\text { assaulted her. After the } \\
\text { victim reported the } \\
\text { incident to the police, } \\
\text { the defendant told the } \\
\text { victim to drop the } \\
\text { report or he would } \\
\text { release the photos. }\end{array}$ & $\begin{array}{l}\text { The jury convicted the } \\
\text { defendant of sexual battery (Cal. } \\
\text { Penal Code (CPC) } \S 243.4(\mathrm{e})(1) \text { ) } \\
\text { and (2)) and attempting to } \\
\text { dissuade a victim and witness } \\
\text { from reporting a crime (CPC } \S \\
\text { 146.1(b)(1)). The trial court } \\
\text { sentenced him to } 120 \text { days in } \\
\text { custody, three years of } \\
\text { probation, and sex offender } \\
\text { registration. } \\
\text { On appeal, the court reversed } \\
\text { the sexual battery charged but } \\
\text { affirmed the second charge. We } \\
\text { could not determine what } \\
\text { sentence the defendant actually } \\
\text { served. }\end{array}$ \\
\hline
\end{tabular}

147 Farrell v. Narain, No. 2:05-cv-07244 (C.D. Cal. Oct 5, 2005); Farrell v. Narain, No. 2:05-cv-05668 (C.D. Cal. Aug. 3, 2005); Farrell v. Narain, No. BC336690, 2005 WL 6522674 (Cal. Super. Ct. 2005); Colin Farrell Sues Over Sex Tape, THE SMOKING GuN (July 19, 2005), http://www.thesmokinggun.com/documents/crime/colin-farrell-suesover-sex-tape [https://perma.cc/78VW-KAYF].

148 People v. Wood, Nos. Do54112 \& Do55201, 2009 Cal. App. Unpub. LEXIS 9959 (Dec. 17, 2009). 


\begin{tabular}{|c|c|c|}
\hline Case Name & Key Facts & Outcome \\
\hline S.B.v. Duffy ${ }^{149}$ & $\begin{array}{l}\text { The victim's ex- } \\
\text { boyfriend threatened } \\
\text { to disseminate nude } \\
\text { photos of the victim on } \\
\text { a website and to her } \\
\text { daughter's father. Even } \\
\text { after a court hearing, } \\
\text { he kept emailing the } \\
\text { victim and posting } \\
\text { information about her } \\
\text { on his website. }\end{array}$ & $\begin{array}{l}\text { The trial court entered a } \\
\text { domestic violence final } \\
\text { restraining order. The appeals } \\
\text { court affirmed. }\end{array}$ \\
\hline $\begin{array}{l}\text { State } v . \\
\text { Stancl }{ }^{150}\end{array}$ & $\begin{array}{l}\text { Stancl pretended to be } \\
\text { a teenage girl on } \\
\text { Facebook and asked } \\
\text { his high school } \\
\text { classmates to send him } \\
\text { nude photos. At least } \\
\text { thirty-one male } \\
\text { classmates did so. } \\
\text { After receiving the } \\
\text { photos, he threatened } \\
\text { to disseminate the } \\
\text { photos unless the } \\
\text { senders had sex with } \\
\text { him. }\end{array}$ & $\begin{array}{l}\text { Stancl was charged with sexual } \\
\text { assault, possession of child } \\
\text { pornography, two counts each of } \\
\text { second- and third-degree sexual } \\
\text { assault, five counts of child } \\
\text { enticement and more. "As part of } \\
\text { a plea agreement, he pleaded no } \\
\text { contest to and was convicted Dec. } \\
22 \text { of two felonies - repeated } \\
\text { sexual assault of the same child } \\
\text { and third-degree sexual assault. } \\
\text { In exchange, the ten other felony } \\
\text { counts were dismissed...."151 He } \\
\text { was sentenced to fifteen years in } \\
\text { prison and thirteen years of } \\
\text { supervised release; he was subject } \\
\text { to a no-contact order; and he was }\end{array}$ \\
\hline
\end{tabular}

149 S.B. v. Duffy, No. A-4495-07T1, 2009 N.J. Super. Unpub. LEXIS 2334 (Ct. App. Div. Aug. 31, 2009).

${ }^{150}$ State v. Stancl, No. 2009 CFooo134 (Wis. Cir. Ct. 2009); Complaint, State v. Stancl, No. 2009CFoo0134 (Wis. Cir. Ct. 2009),

https://www.wired.com/images_blogs/threatlevel/files/redactedstancl.pdf [https://perma.cc/W3FG-GLUC]; Docket, State v. Stancl, No. 2009CFoo0134 (Wis. Cir. Ct. 2009), https://archive.is/ocoW (sentence was twelve years with ten years of supervised release); Susan Saulny, Sex Predator Accusations Shake a Wisconsin Town, N.Y. TimES (Feb. 10, 2009), http://www.nytimes.com/2009/02/11/us/11wisconsin.html [https://perma.cc/2JDV-RZDF]; Laurel Walker, Stancl Gets 15 years in Prison in Facebook Coercion Case, MILWAUKEE J. SENTINEL (Feb. 24, 2010), https://www.liveleak.com/view?i=228_1267116758 [https://perma.cc/CY4E-ZCKW].

${ }^{151}$ Walker, supra note 150. 


\begin{tabular}{|c|c|c|}
\hline Case Name & Key Facts & Outcome \\
\hline & & $\begin{array}{l}\text { required to register as a sex } \\
\text { offender. }{ }^{152}\end{array}$ \\
\hline $\begin{array}{l}\text { People v. } \\
\text { Cavazos }^{153}\end{array}$ & $\begin{array}{l}\text { After they broke up, } \\
\text { the victim's ex- } \\
\text { boyfriend made } \\
\text { unwanted calls and } \\
\text { visits. He also recorded } \\
\text { them having sex and } \\
\text { threatened to } \\
\text { disseminate the } \\
\text { recording to the } \\
\text { Internet or the victim's } \\
\text { family. }\end{array}$ & $\begin{array}{l}\text { A jury convicted the defendant } \\
\text { of stalking, misdemeanor } \\
\text { battery, and violation of a } \\
\text { restraining order. The court } \\
\text { sentenced him to state prison } \\
\text { for two years for stalking, and to } \\
\text { concurrent county jail terms of } \\
237 \text { days on the remaining } \\
\text { counts. The appeals court } \\
\text { affirmed. }\end{array}$ \\
\hline $\begin{array}{l}\text { United States } \\
v . \text { Beckett }^{154}\end{array}$ & $\begin{array}{l}\text { The defendant posed } \\
\text { as a teenage female on } \\
\text { MySpace and solicited } \\
\text { four underage boys to } \\
\text { send nude photos. } \\
\text { Once in possession of } \\
\text { the photos, the } \\
\text { defendant then } \\
\text { threatened to } \\
\text { disseminate photos if } \\
\text { they did not engage in } \\
\text { sexual activity with } \\
\text { him. None of the boys } \\
\text { actually did so. }\end{array}$ & $\begin{array}{l}\text { The defendant was convicted of } \\
\text { one count of child pornography } \\
\text { possession (18 U.S.C. } \S \\
2252 A(a)(5)(B)) ; \text { sixteen counts } \\
\text { of producing child pornography } \\
\text { (18 U.S.C. } \S 2251(a)) \text {; and ( } 3) \\
\text { attempted sexual coercion of } \\
\text { four victims (18 U.S.C. } \S \\
2422(b)) \text {. The appeals court } \\
\text { affirmed. The defendant was } \\
\text { sentenced to 180 months in } \\
\text { prison plus lifetime supervised } \\
\text { release. }\end{array}$ \\
\hline $\begin{array}{l}\text { People } v . \\
\text { Ybarra }^{155}\end{array}$ & $\begin{array}{l}\text { The parties dated. } \\
\text { After they broke up, } \\
\text { the defendant } \\
\text { threatened to send } \\
\text { sexually explicit photos } \\
\text { of the victim to the } \\
\text { victim's cellphone } \\
\text { contacts. }\end{array}$ & $\begin{array}{l}\text { The jury convicted the } \\
\text { defendant of two counts of } \\
\text { making criminal threats (Cal. } \\
\text { Penal Code } \$ 422 \text { ). Combined } \\
\text { with other criminal offenses, the } \\
\text { trial court sentenced him to } \\
\text { twelve years and four months. } \\
\text { The appeals court affirmed. }\end{array}$ \\
\hline
\end{tabular}

152 Id.

153 People v. Cavazos, No. A124274, 2010 Cal. App. Unpub. LEXIS 3420 (May 11, 2010).

154 United States v. Beckett, No. 09-10579, 2010 WL 776049 (11th Cir. Mar. 9, 2010); Beckett v. United States, No. 9:11-cv-80678 (S.D. Fla. June 10, 2011).

155 People v. Ybarra, No. B215202, 2010 WL 4886022 (Cal. Ct. App. Dec. 2, 2010). 


\begin{tabular}{|c|c|c|}
\hline Case Name & Key Facts & Outcome \\
\hline $\begin{array}{l}\text { Serrano v. } \\
\text { Butler }{ }^{156}\end{array}$ & $\begin{array}{l}\text { Ex-boyfriend } \\
\text { attempted to coerce his } \\
\text { ex-girlfriend into } \\
\text { having sex by } \\
\text { threatening to email a } \\
\text { video of her, engaging } \\
\text { in consensual sexual } \\
\text { acts with a previous } \\
\text { boyfriend, to her } \\
\text { employer, school } \\
\text { contacts, and amateur } \\
\text { porn websites. }\end{array}$ & $\begin{array}{l}\text { A jury convicted the defendant } \\
\text { of attempted rape through } \\
\text { coercion, and the court placed } \\
\text { him on three years' probation. } \\
\text { The appeals court affirmed. The } \\
\text { California Supreme Court } \\
\text { denied review. The defendant } \\
\text { sought a writ of habeas corpus, } \\
\text { which was denied. }\end{array}$ \\
\hline $\begin{array}{l}\text { United States } \\
v . \text { Shea }^{157}\end{array}$ & $\begin{array}{l}\text { Defendant captured } \\
\text { live web images of } \\
\text { minor females } \\
\text { exposing their breasts. } \\
\text { Defendant then } \\
\text { discovered the identity } \\
\text { of the girls and } \\
\text { threatened to send the } \\
\text { photos to the victim's } \\
\text { friends and family if } \\
\text { they did not send more } \\
\text { explicit images to the } \\
\text { defendant. }\end{array}$ & $\begin{array}{l}\text { Defendant pled guilty to sexual } \\
\text { exploitation of minors ( } 18 \\
\text { U.S.C. } § 2251(a) \text { ) and was } \\
\text { sentenced to } 396 \text { months in } \\
\text { prison. The appeals court } \\
\text { affirmed. }\end{array}$ \\
\hline $\begin{array}{l}\text { Williams } v . \\
\text { Williams }^{158}\end{array}$ & $\begin{array}{l}\text { The parties were } \\
\text { married. After they } \\
\text { separated, the } \\
\text { defendant harassed the } \\
\text { plaintiff, including } \\
\text { threats to send nude } \\
\text { photos of the plaintiff } \\
\text { to the plaintiff and her } \\
\text { church leader. }\end{array}$ & $\begin{array}{l}\text { The court issued a civil stalking } \\
\text { injunction against the } \\
\text { defendant. The appeals court } \\
\text { affirmed. }\end{array}$ \\
\hline $\begin{array}{l}\text { Backlund v. } \\
\text { Stone } 159\end{array}$ & $\begin{array}{l}\text { Stone operated a } \\
\text { website called }\end{array}$ & $\begin{array}{l}\text { Backlund sued Stone for public } \\
\text { disclosure of private facts, }\end{array}$ \\
\hline
\end{tabular}

${ }^{156}$ Serrano v. Butler, No. C 06-04433 JW, 2010 U.S. Dist. LEXIS. 137617 (N.D. Cal. Dec. 20, 2010).

157 United States v. Shea, Nos. 12-1190 \& 12-1191, 2012 U.S. App. LEXIS 20151 (7th Cir. Sept. 26, 2012).

${ }_{158}$ Williams v. Williams, 301 P.3d 1043 (Utah Ct. App. 2013). 


\begin{tabular}{|c|c|c|}
\hline Case Name & Key Facts & Outcome \\
\hline & $\begin{array}{l}\text { StickyDrama.com. He } \\
\text { posted a nude image of } \\
\text { a third-party child that } \\
\text { he falsely said depicted } \\
\text { Backlund, and } \\
\text { included her contact } \\
\text { information. } \\
\text { Subsequently, Stone } \\
\text { tweeted that he would } \\
\text { disseminate a topless } \\
\text { photo of Backlund if } \\
\text { she contacted Stone's } \\
\text { roommate again. }\end{array}$ & $\begin{array}{l}\text { defamation, and false light } \\
\text { based on his threatening tweet. } \\
\text { Stone brought an unsuccessful } \\
\text { anti-SLAPP motion. He also } \\
\text { cross-sued Backlund for } \\
\text { defamation and IIED based on } \\
\text { an interview she did. The } \\
\text { appeals court granted } \\
\text { Backlund's anti-SLAPP motion, } \\
\text { and the trial court awarded her } \\
\text { nearly } \$ 110, \text { ooo in attorney's } \\
\text { fees and costs. } \\
\text { On the merits, the trial court } \\
\text { awarded Backlund } \$ 250, \text { ooo for } \\
\text { pain and suffering, } \$ 250, \text { ooo } \\
\text { for emotional distress, } \$ 320 \text { for } \\
\text { lost earnings, } \$ 500, \text { ooo } \\
\text { punitive damages and attorney's } \\
\text { fees and costs of nearly } \\
\$ 130, \text { ooo (a total award of over } \\
\$ 1.1 \text { million).16o The court also } \\
\text { awarded an injunction against } \\
\text { further defamation. }\end{array}$ \\
\hline $\begin{array}{l}\text { E.C.v. C.B.T., } \\
\text { Sr. }{ }^{161}\end{array}$ & $\begin{array}{l}\text { The victim alleged that } \\
\text { her ex-boyfriend } \\
\text { stalked and threatened } \\
\text { her, including threats } \\
\text { to disseminate sexual } \\
\text { photos of her on } \\
\text { Craigslist and "other } \\
\text { dirty sites." }\end{array}$ & $\begin{array}{l}\text { The trial court issued a } \\
\text { restraining order based on the } \\
\text { Prevention of Domestic } \\
\text { Violence Act (N.J.S.A. } 2 \text { C:25-17 } \\
\text { to - } 35 \text { ). The appeals court } \\
\text { reversed because the record did } \\
\text { not prove the defendant's } \\
\text { conduct caused the victim to } \\
\text { fear for her safety. }\end{array}$ \\
\hline
\end{tabular}

159 Backlund v. Stone, No. B235173, 2012 WL 3800883 (Cal. Ct. App. Sept. 4, 2012); Complaint, Backlund v. Stone, No. BC449910, 2013 WL 3835962 (Cal. Super. Ct. May 13, 2013); Complaint, Backlund v. Stone, No. BC449910 (Cal. Super. Ct. Dec. 11, 2013), http://digitalcommons.law.scu.edu/cgi/viewcontent.cgi?article=2375\&context=historical [https://perma.cc/XM9D-3YV7].

${ }^{160}$ These damage amounts apparently cover both the dissemination-related claims and others.

${ }_{161}$ E.C. v. C.B.T., Sr., No. A-1185-12T2, 2013 WL 1858859 (N.J. Super. Ct. App. Div. May 6, 2013), http://njlaw.rutgers.edu/collections/courts/appellate/a1185-12.opn.html

[https://perma.cc/D9LQ-2ZL8]. 


\begin{tabular}{|c|c|c|}
\hline Case Name & Key Facts & Outcome \\
\hline $\begin{array}{l}\text { United States } \\
v . \text { Esler }^{162}\end{array}$ & $\begin{array}{l}\text { Defendant met the } \\
\text { minor victim online } \\
\text { and got the victim to } \\
\text { send explicit photos. } \\
\text { The defendant then } \\
\text { threatened to post the } \\
\text { photos if the victim did } \\
\text { not provide more } \\
\text { photos. }\end{array}$ & $\begin{array}{l}\text { Defendant pled guilty to receipt } \\
\text { of child pornography (18 U.S.C. } \\
\S 2252(\mathrm{a})(2)) \text {. The district court } \\
\text { sentenced him to seventy } \\
\text { months in prison followed by a } \\
\text { twenty-year term of supervised } \\
\text { release. The court further } \\
\text { ordered } \$ 37,750 \text { in mandatory } \\
\text { restitution pursuant to } 18 \text { U.S.C. } \\
\S 3663(\text { a) and } \S 2259 \text {. The } \\
\text { appeals court affirmed. }\end{array}$ \\
\hline $\begin{array}{l}\text { People v. } \\
\text { Piznarski163 }\end{array}$ & $\begin{array}{l}\text { While dating, Piznarski } \\
\text { made an unauthorized } \\
\text { recording of sexual } \\
\text { activity with the } \\
\text { victim. After they } \\
\text { broke up, Piznarski } \\
\text { threatened to } \\
\text { disseminate the first } \\
\text { recording if she did not } \\
\text { engage in more sexual } \\
\text { activity with him while } \\
\text { he recorded it. The } \\
\text { victim acquiesced to } \\
\text { this demand. } \\
\text { Investigators later } \\
\text { discovered that the } \\
\text { defendant had made } \\
\text { an unauthorized } \\
\text { recording of sexual } \\
\text { activity with a second } \\
\text { victim. }\end{array}$ & $\begin{array}{l}\text { Piznarski was charged with two } \\
\text { counts of unlawful surveillance } \\
\text { in the second degree, criminal } \\
\text { sexual act in the third degree, } \\
\text { two counts of coercion in the } \\
\text { second degree, unlawful } \\
\text { imprisonment in the second } \\
\text { degree, and (regarding the } \\
\text { second victim) three counts of } \\
\text { unlawful surveillance in the } \\
\text { second degree. A jury convicted } \\
\text { him of all charges except the } \\
\text { unlawful imprisonment. The } \\
\text { court sentenced him to one to } \\
\text { three years in prison (with } \\
\text { several concurrent sentences of } \\
\text { lesser duration), issued } \\
\text { protective orders for both } \\
\text { victims, ordered him to pay } \\
\text { restitution, and classified him as } \\
\text { a Level } 1 \text { sex offender. The } \\
\text { appeals court affirmed the } \\
\text { conviction. }\end{array}$ \\
\hline $\begin{array}{l}\text { United States } \\
v . \text { Tarlow }{ }^{164}\end{array}$ & $\begin{array}{l}\text { Tarlow and the victim } \\
\text { dated, and she }\end{array}$ & $\begin{array}{l}\text { Tarlow was prosecuted for } \\
\text { making a threat pursuant to } 18\end{array}$ \\
\hline
\end{tabular}

162 United States v. Esler, No. 11-30479, 2013 WL 3185779 (5th Cir. June 24, 2013).

163 People v. Piznarski, 2013 N.Y. App. Div. LEXIS 8089 (2013); People v. Piznarski, 2014 N.Y. Misc. LEXIS 5373 (Sup. Ct. 2014).

164 Complaint, United States v. Tarlow, No. 3:15-cr-00239 (N.D. Cal. Apr. 30, 2015); Billionaire's Kin Targeted In Naked Photos Extortion, THE SMOKING Gun (Apr. 23, 2014), http://www.thesmokinggun.com/documents/Khosla-family-extortion-plot-576432/ [https://perma.cc/7K72-43AP]. 


\begin{tabular}{|c|c|c|}
\hline Case Name & Key Facts & Outcome \\
\hline & $\begin{array}{l}\text { provided him with } \\
\text { nude photos. After } \\
\text { they broke up, he sent } \\
\text { some of the photos to } \\
\text { the victim's mom and } \\
\text { threatened to } \\
\text { disseminate the photos } \\
\text { more widely unless the } \\
\text { mom paid him money. }\end{array}$ & $\begin{array}{l}\text { U.S.C. § 875(d). He pled guilty } \\
\text { and was subject to a diversion } \\
\text { agreement, which he } \\
\text { successfully completed. }\end{array}$ \\
\hline $\begin{array}{l}\text { Clark v. } \\
\text { McLane }^{165}\end{array}$ & $\begin{array}{l}\text { The victim's ex- } \\
\text { boyfriend threatened } \\
\text { to post nude photos to } \\
\text { a website and share the } \\
\text { website with her } \\
\text { friends and colleagues. } \\
\text { The ex-boyfriend } \\
\text { created a placeholder } \\
\text { website that said nude } \\
\text { photos were coming. }\end{array}$ & $\begin{array}{l}\text { Before the photos were } \\
\text { disseminated, the court issued a } \\
\text { protective order to prevent } \\
\text { "abusive" humiliation of the } \\
\text { victim. }\end{array}$ \\
\hline $\begin{array}{l}\text { United States } \\
v \text {. } \\
\text { Hutchinson }^{166}\end{array}$ & $\begin{array}{l}\text { Defendant created fake } \\
\text { online profiles to } \\
\text { communicate with } \\
\text { underage female } \\
\text { victims and persuade } \\
\text { them to send nude } \\
\text { photos and contact } \\
\text { information. After } \\
\text { receiving the photos, } \\
\text { the defendant would } \\
\text { extort more photos by } \\
\text { threatening to post the } \\
\text { received photos online, } \\
\text { threatening to send } \\
\text { them to the victims' } \\
\text { families, or threatening } \\
\text { to harm the victim or } \\
\text { their families. On some } \\
\text { occasions, the } \\
\text { defendant did post } \\
\text { photos and videos of }\end{array}$ & $\begin{array}{l}\text { Defendant was charged with } \\
\text { twenty-four counts of federal } \\
\text { child-sex crimes. Defendant } \\
\text { pled guilty to sexual exploitation } \\
\text { of children (18 U.S.C. } \S 2251(a) \\
\text { and (e)), enticement of minors } \\
\text { of engage in criminal sexual } \\
\text { activity (18 U.S.C. } \S 2422(\mathrm{~b}) \text { ), } \\
\text { and transferring obscene } \\
\text { materials to minors (18 U.S.C. } \S \\
\text { 1470). Defendant was sentenced } \\
\text { to life imprisonment. The } \\
\text { appeals court affirmed. }\end{array}$ \\
\hline
\end{tabular}

165 Clark v. McLane, 86 A.3d 655 (Me. 2014).

166 United States v. Hutchinson, 588 F. App’x 894 (11th Cir. 2014). 


\begin{tabular}{|c|c|c|}
\hline Case Name & Key Facts & Outcome \\
\hline & $\begin{array}{l}\text { victims who did not } \\
\text { comply with his } \\
\text { demands. }\end{array}$ & \\
\hline $\begin{array}{l}\text { Rogers } v . \\
\text { Brindle }^{167}\end{array}$ & $\begin{array}{l}\text { A woman } \\
\text { surreptitiously } \\
\text { recorded a consensual } \\
\text { sexual encounter with } \\
\text { Rogers and then } \\
\text { threatened to } \\
\text { disseminate the } \\
\text { recording. }\end{array}$ & $\begin{array}{l}\text { Rogers sought to enjoin the } \\
\text { video's dissemination based on } \\
\text { invasion of privacy and IIED. }{ }^{168} \\
\text { The trial court ruled that Rogers } \\
\text { had a right to privacy in his } \\
\text { bedroom, where the recording } \\
\text { took place, and that the video } \\
\text { recording was illegal. }{ }^{169} \text { The } \\
\text { court awarded attorney's fees } \\
\text { and litigation expenses to } \\
\text { Rogers of } \$ 142,656.82 .{ }^{170} \\
\text { Rogers also sued the attorneys } \\
\text { representing the woman, } \\
\text { alleging they contributed to } \\
\text { extortion. }{ }^{171}\end{array}$ \\
\hline $\begin{array}{l}\text { State v. } \\
\text { Schnitker }{ }^{172}\end{array}$ & $\begin{array}{l}\text { Defendant searched } \\
\text { social media sites for }\end{array}$ & $\begin{array}{l}\text { Defendant entered a voluntary } \\
\text { plea agreement and was }\end{array}$ \\
\hline
\end{tabular}

167 Rogers v. Brindle, 12-1-08807-53 (Ga. Super. Ct.); Juan Carlos Rodriquez, Taped Sex Act Violated Waffle House CEO's Privacy: Judge, LAW360 (June 17, 2013), http://www.law36o.com/articles/450665/taped-sex-act-violated-waffle-house-ceo-sprivacy-judge [https://perma.cc/A85N-CWYQ]; Complaint, Rogers v. Cohen, No. 14-14143-53, 2014 WL 3107893 (Ga. Super. Ct. May 30, 2014),

|http://media.cmgdigital.com/shared/news/documents/2014/o6/10/1462684.pdf [https://perma.cc/4D6X-8TYD]. According to the complaint $\llbracket 51$, "On October 16, 2012, the Court in the Fulton County Action entered a written Order confirming the oral ruling made on the record during the evidentiary hearing, finding that Rogers had a right to privacy in his bedroom and bathroom and finding that the video recording of Rogers violated criminal statute O.C.G.A. § 16-11-62." ๆ61 further indicates an attorneys' fee award to Rogers of over $\$ 140,000$.

168 Cohen v. Rogers, 789 S.E.2d 352 (Ga. Ct. App. 2016), http://caselaw.findlaw.com/gacourt-of-appeals/1742437.html [https://perma.cc/8SPS-R5ME].

169 Jury Trial Demand, Rogers v. Cohen et al., No. 14-1-4143-53 (Ga. Super. Ct. 2014), http://media.cmgdigital.com/shared/news/documents/2014/06/10/1462684.pdf [https://perma.cc/4D6X-8TYD].

${ }^{170} \mathrm{Id}$. at 15 .

${ }^{171}$ Katheryn Hayes Tucker, Judge Rules Lawyers Must Face Suit Over Illegal Sex Video, LAW.COM (Feb. 17, 2016), http://www.law.com/sites/articles/2016/02/17/judge-ruleslawyers-must-face-suit-over-illegal-sex-video/ [https://perma.cc/NH2W-B5R6].

${ }_{172}$ State v. Schnitker, 2015 Ohio 1685 (Ohio Ct. App. 2015). 


\begin{tabular}{|c|c|c|}
\hline Case Name & Key Facts & Outcome \\
\hline & $\begin{array}{l}\text { girls aged nine to } \\
\text { fourteen, befriended } \\
\text { them, and convinced } \\
\text { them to send explicit } \\
\text { photos of themselves. } \\
\text { When girls refused to } \\
\text { send more photos, the } \\
\text { defendant threatened } \\
\text { to post the already- } \\
\text { received images online. }\end{array}$ & $\begin{array}{l}\text { convicted of pandering sexually } \\
\text { oriented materials involving a } \\
\text { minor (Ohio Rev. Code } \S \\
2907 \cdot 322 \text { ). Defendant was } \\
\text { sentenced to fourteen years in } \\
\text { prison. The appeals court } \\
\text { affirmed. }\end{array}$ \\
\hline $\begin{array}{l}\text { United States } \\
v \text {. Ackell } 173\end{array}$ & $\begin{array}{l}\text { Defendant threatened } \\
\text { to distribute explicit } \\
\text { photos of the victim if } \\
\text { she stopped } \\
\text { communicating with } \\
\text { him or failed to } \\
\text { provide additional } \\
\text { photos upon his } \\
\text { request. }\end{array}$ & $\begin{array}{l}\text { Defendant was convicted of } \\
\text { cyberstalking (18 U.S.C. } \S \\
2261 \mathrm{~A}(2)(\mathrm{B})) \text {. The district court } \\
\text { rejected the defendant's } \\
\text { constitutional challenges to the } \\
\text { statute and various post-trial } \\
\text { motions. He was sentenced to } \\
33 \text { months in prison, } 3 \text { years of } \\
\text { supervised release and a } \$ 100 \\
\text { special assessment. }\end{array}$ \\
\hline $\begin{array}{l}\text { United States } \\
v \text {. Browne }{ }^{174}\end{array}$ & $\begin{array}{l}\text { The defendant solicited } \\
\text { sexual photos from } \\
\text { minors and one adult } \\
\text { via Facebook. Once he } \\
\text { received the photos, he } \\
\text { threatened to } \\
\text { disseminate them } \\
\text { online unless the } \\
\text { victims agreed to } \\
\text { engage in sexual acts } \\
\text { with him. }\end{array}$ & $\begin{array}{l}\text { The jury convicted the } \\
\text { defendant of: four counts of } \\
\text { producing child pornography } \\
\text { (18 U.S.C. } \S 2251(\text { a)); coercion } \\
\text { and enticement of a minor to } \\
\text { engage in sex ( } 18 \text { U.S.C. } \S \\
2422(b) \text { ); three counts of receipt } \\
\text { of child pornography (18 U.S.C. } \\
\S 2252(\text { a) }(2) \text { ); and three counts } \\
\text { of transferring obscene material } \\
\text { to minors (18 U.S.C. } \S 1470) \text {. } \\
\text { The jury acquitted the } \\
\text { defendant on other counts, and } \\
\text { several charges were dismissed } \\
\text { before the jury trial. The appeals } \\
\text { court affirmed, and the } \\
\text { Supreme Court denied } \\
\text { certiorari. }\end{array}$ \\
\hline
\end{tabular}

173 United States v. Ackell, No. 15-cr-123-JL, 2016 U.S. Dist. LEXIS 149751 (D. N.H. Oct. 28, 2016); United States v. Ackell, 2017 WL 2913452 (D. N.H. July 7, 2017).

174 United States v. Browne, 834 F.3d 403 (3d Cir. 2016); cert denied, Browne v. United States, 137 S.Ct. 695 (2017). 


\section{APPENDIX D}

\section{ACTIONS AGAINST INTERMEDIARIES}

\begin{tabular}{|c|c|c|}
\hline Case Name & Key Facts & Outcome \\
\hline $\begin{array}{l}\text { The Pamela } \\
\text { Anderson and } \\
\text { Tommy Lee } \\
\text { cases }^{175}\end{array}$ & $\begin{array}{l}\text { A video of Pamela } \\
\text { Anderson Lee and } \\
\text { Tommy Lee having sex } \\
\text { was stolen and } \\
\text { disseminated widely. }\end{array}$ & $\begin{array}{l}\text { This recording spurred } \\
\text { numerous lawsuits. Some } \\
\text { of the most noteworthy } \\
\text { developments include: } \\
\text { publicity and privacy } \\
\text { claims against Penthouse } \\
\text { and Paramount failed } \\
\text { because the video was } \\
\text { deemed newsworthy; a } \\
\text { copyright claim against } \\
\text { Paramount failed on fair } \\
\text { use grounds; the court } \\
\text { denied an injunction } \\
\text { against Internet } \\
\text { Entertainment Group, } \\
\text { and eventually Pamela } \\
\text { and Tommy settled with } \\
\text { IEG but were not paid } \\
\text { some/all of the settlement } \\
\text { amounts. }{ }^{176}\end{array}$ \\
\hline $\begin{array}{l}\text { The Scott } \\
\text { Stapp/Kid Rock } \\
\text { Sex Tape cases }{ }^{177}\end{array}$ & $\begin{array}{l}\text { A website, World Wide } \\
\text { Red Light District, } \\
\text { published a video of } \\
\text { famous rock singers Kid }\end{array}$ & $\begin{array}{l}\text { One of the depicted } \\
\text { women sued the website } \\
\text { and Stapp for privacy } \\
\text { invasion, publicity rights }\end{array}$ \\
\hline
\end{tabular}

175 Lee v. Penthouse Int'l, No. CV 96-7069 SVW (JGx), 1997 U.S. Dist. LEXIS 23893 (C.D. Cal. Mar. 18, 1997); Michaels v. Internet Entm't Grp., Inc., 5 F. Supp. 2d 823 (C.D. Cal. 1998); Michaels v. Internet Entm't Grp., No. CV 98-0583 DDP (CWx), 1998 U.S. Dist. LEXIS 20786 (C.D. Cal. Sept. 10, 1998).

${ }^{176}$ Amanda Chicago Lewis, Pam and Tommy: The Untold Story of the World's Most Infamous Sex Tape, RolLING STONE (Dec. 22, 2014), http://www.rollingstone.com/culture/features/pam-and-tommy-the-untold-story-of-theworlds-most-infamous-sex-tape-20141222 [https://perma.cc/JVE7-8EN8].

177 Doe v. World Wide Red Light District, No. 2006-004056-CA-01 (Fla. Cir. Ct. complaint filed Mar. 2, 2006), http://www.thesmokinggun.com/file/groupie-sues-over-rock-stappsex-video; Stapp v. Worldwide Red Light District, Docket No. 2:06-cv-01570 (C.D. Cal. complaint filed Mar. 14, 2006); Ritchie v. World Wide Red Light District, No. 2:06-cv10769 (E.D. Mich. complaint filed Feb. 21, 2006). 


\begin{tabular}{|c|c|c|}
\hline Case Name & Key Facts & Outcome \\
\hline & $\begin{array}{l}\text { Rock and Scott Stapp } \\
\text { (from the band Creed) } \\
\text { having sex with four } \\
\text { women on a bus. }\end{array}$ & $\begin{array}{l}\text { violations, and IIED. The } \\
\text { court denied her request } \\
\text { to sue anonymously. } \\
\text { Stapp sued the website for } \\
\text { copyright infringement } \\
\text { and more. That case } \\
\text { settled. } \\
\text { Kid Rock sued the website } \\
\text { for publicity rights, } \\
\text { trademark infringement } \\
\text { and privacy invasion. The } \\
\text { court granted a TRO and } \\
\text { then approved a } \\
\text { stipulated injunction. }\end{array}$ \\
\hline $\begin{array}{l}\text { Barnes } v . \\
\text { Yahoo }^{178}\end{array}$ & $\begin{array}{l}\text { Ex-boyfriend created } \\
\text { fake profiles on Yahoo- } \\
\text { operated sites in the } \\
\text { victim's name and } \\
\text { posted nude photos } \\
\text { along with the victim's } \\
\text { contact information, } \\
\text { which led to unwanted } \\
\text { contact by third parties. }\end{array}$ & $\begin{array}{l}\text { The victim sued Yahoo for } \\
\text { negligence. The lower } \\
\text { court dismissed on } \\
\text { Section } 230 \text {. The appeals } \\
\text { court affirmed the } \\
\text { negligence dismissal but } \\
\text { said the plaintiff could } \\
\text { pursue a promissory } \\
\text { estoppel claim, which was } \\
\text { not preempted by Section } \\
\text { 230. The case } \\
\text { subsequently settled. }\end{array}$ \\
\hline Doe v. Peterson ${ }^{179}$ & $\begin{array}{l}\text { The victim provided } \\
\text { explicit photos to her ex- } \\
\text { boyfriend. Those photos } \\
\text { appeared on various } \\
\text { websites, including } \\
\text { exgfpics.com, run by } \\
\text { Peterson. The litigants } \\
\text { disputed whether the } \\
\text { victim was a minor or } \\
\text { adult when she took the } \\
\text { photos. }\end{array}$ & $\begin{array}{l}\text { The victim sued for civil } \\
\text { violations of the federal } \\
\text { child pornography } \\
\text { distribution law (18 U.S.C. } \\
\S 2252 \mathrm{~A}(\mathrm{a})(2)) \text {. The } \\
\text { district court denied the } \\
\text { victim's summary } \\
\text { judgment motion, and the } \\
\text { parties settled. }\end{array}$ \\
\hline GoDaddy.com & The plaintiffs alleged & The plaintiffs sued for \\
\hline
\end{tabular}

178 Barnes v. Yahoo!, Inc., 570 F.3d 1096 (9th Cir. 2009); Barnes v. Yahoo!, Inc., No. 05926-AA, 2009 U.S. Dist. LEXIS 116274 (D. Or. Dec. 8, 2009); see also Barnes v. Yahoo!, Inc., 2005 WL 3005602 (D. Or. Nov. 8, 2005).

179 Doe v. Peterson, 784 F. Supp. 2 d 831 (E.D. Mich. 2011). 


\begin{tabular}{|c|c|c|}
\hline Case Name & Key Facts & Outcome \\
\hline$L L C v$. Toups $^{180}$ & $\begin{array}{l}\text { that GoDaddy failed to } \\
\text { remove "revenge porn" } \\
\text { websites that it hosted. }\end{array}$ & $\begin{array}{l}\text { gross negligence and } \\
\text { IIED. GoDaddy defended } \\
\text { on Section 230. The lower } \\
\text { court denied GoDaddy's } \\
\text { motion to dismiss. The } \\
\text { appeals court reversed, } \\
\text { dismissing the case on } \\
\text { Section } 230 \text { grounds. }\end{array}$ \\
\hline $\begin{array}{l}\text { Conklin } v . \\
\text { PinkMeth.com } \\
181\end{array}$ & $\begin{array}{l}\text { The victim sued a } \\
\text { "revenge porn" website } \\
\text { and the TOR Network. }\end{array}$ & $\begin{array}{l}\text { The TOR Network was } \\
\text { dropped from the } \\
\text { lawsuit.182 Plaintiff's } \\
\text { counsel reported that the } \\
\text { court granted "a } \\
\$ 1,000,000.00 \text { default } \\
\text { judgment and a } \\
\text { permanent injunction." }{ }^{8} 3\end{array}$ \\
\hline Doe v. Bollaert ${ }^{184}$ & $\begin{array}{l}\text { Bollaert, Amy Chanson, } \\
\text { Roy Chanson and others } \\
\text { operated YouGotPosted, } \\
\text { a website that solicited } \\
\text { sexually explicit photos } \\
\text { along with the depicted } \\
\text { individuals' name, }\end{array}$ & $\begin{array}{l}\text { Bollaert and the Chansons } \\
\text { defaulted. The judge } \\
\text { found they knowingly } \\
\text { distributed child } \\
\text { pornography ( } 18 \text { U.S.C. } \S \\
2252 A \text { ) and violated the } \\
\text { victim's publicity rights }\end{array}$ \\
\hline
\end{tabular}

180 GoDaddy.com, LLC v. Toups, 429 S.W.3d 752 (Tex. App. 2014).

${ }^{181}$ Conklin v. PinkMeth.com, No. 14-04555431 (Tex. Dist. Ct. complaint filed June 17, 2014), https://www.scribd.com/doc/233081133/233038130-Pink-Meth-Summons-andComplaint [https://perma.cc/D8KN-8TB7].

182 Mike Masnick, Ridiculous Lawsuit Filed (And Now Dropped) Against Tor Project Gets Even More Ridiculous: Now Involving Hate Group Leader, TECHDIRT (July 10, 2014), https://www.techdirt.com/articles/20140709/18055527833/ridiculous-lawsuit-filedagainst-tor-project-gets-even-more-ridiculous-now-involving-hate-group-leader.shtml [https://perma.cc/RL5C-QKM4].

183 Email from Jason Lee Van Dyke to Eric Goldman (dated July 27, 2017) (on file with Eric Goldman).

184 Complaint, Doe v. Bollaert, No. 2:13-CV-486 (S.D. Ohio May 21, 2013), http://www.plainsite.org/dockets/download.html?id=3231146o\&z=ddo41foe [https://perma.cc/5MEV-24RR]; Order, Doe v. Bollaert, No. 2:13-CV-486 (S.D. Ohio Mar. 18, 2014), http://www.plainsite.org/dockets/download.html?id=167384616\&z=of1b373e [https://perma.cc/7PAM-T8VC]; see also Press Release, State of California Department of Justice, Office of the Attorney General, Attorney General Kamala D. Harris Announces 18 year Prison Sentence for Cyber-Exploitation Website Operator (Apr. 3, 2015), https://oag.ca.gov/news/press-releases/attorney-general-kamala-d-harris-announces-18year-prison-sentence-cyber [https://perma.cc/P5VP-UMBE]; supra note 176. 


\begin{tabular}{|c|c|c|}
\hline Case Name & Key Facts & Outcome \\
\hline & $\begin{array}{l}\text { location, age, and } \\
\text { Facebook profile link. } \\
\text { Bollaert operated a } \\
\text { second website where } \\
\text { depicted individuals } \\
\text { could pay-to-remove the } \\
\text { photos. The plaintiff } \\
\text { discovered that several } \\
\text { sexually explicit photos, } \\
\text { taken when she was a } \\
\text { minor, were posted to } \\
\text { the website. }\end{array}$ & $\begin{array}{l}\text { (Ohio Revised Code } \S \\
\text { 2741.02). The court } \\
\text { awarded } \$ 385, \text { ooo in } \\
\text { damages, consisting of } \\
\$ 300, \text { ooo for the child } \\
\text { porn violations, } \$ 10,000 \\
\text { for the publicity rights } \\
\text { violations, and } \$ 75, \text { ooo in } \\
\text { punitive damages. The } \\
\text { victim later settled with } \\
\text { the Chansons. } 185\end{array}$ \\
\hline $\begin{array}{l}\text { Talley } v . \\
\text { Chanson } \\
186\end{array}$ & $\begin{array}{l}\text { Similar facts to Doe } v \text {. } \\
\text { Bollaert. }\end{array}$ & $\begin{array}{l}\text { The judge granted a } \\
\text { default judgment } \\
\text { including a permanent } \\
\text { injunction. The judge } \\
\text { awarded the plaintiffs } \\
\$ 450, \text { ooo from each of } \\
\text { the two defendants (a } \\
\text { total of } \$ 900,000 \text { ). Each } \\
\text { damages award consisted } \\
\text { of } \$ 150, \text { ooo for the child } \\
\text { porn violations (18 U.S.C. } \\
\S \S 2252 \& 2252 A) \text {, } \\
\$ 150, \text { ooo for associated } \\
\text { punitive damages, and } \\
\$ 150,000 \text { for statutory } \\
\text { publicity rights violations } \\
\text { (Cal. Civil Code } \S \\
3344(a) \text { ) The defendants } \\
\text { were enjoined from using } \\
\text { the photos and ordered to }\end{array}$ \\
\hline
\end{tabular}

185 See Stipulation of Dismissal with Prejudice and Order by Plaintiff Jane Doe, No. 2:13CV-485 (S.D. Ohio June 16, 2014); Joint Stipulation for Dismissal with Prejudice and Order, Doe v. Bollaert, No. 2:13-CV-486 (S.D. Ohio June 17, 2014), http://www.plainsite.org/dockets/download.html?id=167384619\&z=95bc33b1 [https://perma.cc/24XT-A98A].

${ }^{186}$ Order Granting Motion for Default Judgment Against Defendants Eric Chanson and Kevin Bollaert, No. 13-CV-1238-CAB-BLM (S.D. Cal. Feb. 25, 2015), https://randazza.files.wordpress.com/2015/o2/040-order-granting-motion-for-defaultjudgment.pdf [https://perma.cc/VXW6-K4C2]. The Chansons also were sued over the "IsAnyoneUp?" trademarks. See ViaView, Inc. v. Chanson, 2013 WL 1405353 (D. Nev. Apr. 4, 2013); ViaView, Inc. v. Blue Mist Media, 2012 WL 6007204 (D. Nev. Nov. 30, 2012). 


\begin{tabular}{|c|c|c|}
\hline Case Name & Key Facts & Outcome \\
\hline & & destroy them. \\
\hline $\begin{array}{l}\text { People } v . \\
\text { Bollaert }^{187}\end{array}$ & $\begin{array}{l}\text { As described above, } \\
\text { Bollaert operated a } \\
\text { pornographic website } \\
\text { requesting user } \\
\text { submissions and a } \\
\text { separate service offering } \\
\text { a way to pay-to-remove } \\
\text { submissions. }\end{array}$ & $\begin{array}{l}\text { The court convicted } \\
\text { Bollaert of extortion (Cal. } \\
\text { Penal Code } \S 520 \text { ) and } \\
\text { identity theft (Cal. Penal } \\
\text { Code } \S 530.5 \text { ) and } \\
\text { sentenced him to eighteen } \\
\text { years in prison; later } \\
\text { reduced to eight years in } \\
\text { jail plus ten years } \\
\text { mandatory supervision in } \\
\text { the community. }{ }^{188} \text { He was } \\
\text { also ordered to pay } \\
\$ 15, \text { ooo in restitution and } \\
\text { a } \$ 10, \text { ooo fine. The } \\
\text { appeals court affirmed the } \\
\text { conviction, holding that } \\
47 \text { U.S.C. } \S 230 \text { did not } \\
\text { apply to Bollaert. }{ }^{2} 9\end{array}$ \\
\hline $\begin{array}{l}\text { WinByState } \\
\text { Prosecution } \\
\text { (Casey } \\
\text { Meyering)190 }\end{array}$ & $\begin{array}{l}\text { Defendant operated a } \\
\text { website, } \\
\text { WinByState.com, which } \\
\text { requested users to }\end{array}$ & $\begin{array}{l}\text { Defendant pled no contest } \\
\text { to extortion, attempted } \\
\text { extortion (three counts), } \\
\text { and conspiracy. }\end{array}$ \\
\hline
\end{tabular}

187 Press Release, State of California Department of Justice, Office of the Attorney General, Attorney General Kamala D. Harris Announces 18 year Prison Sentence for CyberExploitation Website Operator (Apr. 3, 2015), https://oag.ca.gov/news/pressreleases/attorney-general-kamala-d-harris-announces-18-year-prison-sentence-cyber [https://perma.cc/6W9Y-AQ8R].

188 Terry Carter, Revenge Porn Website Operator Has His Sentence Reduced by Judge, ABA J. (Sept. 22, 2015), http://www.abajournal.com/news/article/revenge_porn_site_operator_has_his_sentenc e_reduced_by_judge [https://perma.cc/BQV7-WJ42]; Laurie Hanna, 'Revenge Porn' Website Owner Kevin Bollaert Has Sentence Reduced by 10 Years, N.Y. DAILY NEWS (Sept. 23, 2015), http://www.nydailynews.com/news/national/revenge-porn-websiteowner-sentence-reduced-article-1.2370925 [https://perma.cc/UGL6-5DMV].

189 People v. Bollaert, 248 Cal. App. 4th 699 (2016).

190 Unfortunately, we have not found original source materials in this case, so we relied on press releases from the California Department of Justice. See Press Release, Attorney General Kamala D. Harris Announces Arrest of Revenge Porn Operator in Oklahoma, STATE OF CALIFORNIA DEPT. OF JUSTICE, OFFICE OF THE ATTORNEY GENERAL (Feb. 14, 2014), https://oag.ca.gov/news/press-releases/attorney-general-kamala-d-harris-announcesarrest-revenge-porn-operator-oklahoma [https://perma.cc/HN3E-VAZ7] ; Press Release, Attorney General Kamala D. Harris Announces Three-Year Sentence for Cyber Exploitation Website Operator, STATE OF CALIFORNIA DEPT. OF JUSTICE, OFFICE OF THE 


\begin{tabular}{|c|c|c|}
\hline Case Name & Key Facts & Outcome \\
\hline & $\begin{array}{l}\text { submit sexually explicit } \\
\text { photos, posted them } \\
\text { (including allegedly at } \\
\text { least one minor), and } \\
\text { charged victims } \$ 250 \text { to } \\
\text { remove postings. }\end{array}$ & $\begin{array}{l}\text { Defendant was sentenced } \\
\text { to three years in jail. }\end{array}$ \\
\hline In re Brittain ${ }^{191}$ & $\begin{array}{l}\text { The defendant allegedly } \\
\text { ran a website soliciting } \\
\text { the anonymous } \\
\text { submission of } \\
\text { nonconsensual } \\
\text { pornography (plus } \\
\text { personal information } \\
\text { about depicted } \\
\text { individuals, such as their } \\
\text { full names, locations, } \\
\text { phone numbers, and } \\
\text { Facebook profiles) and } \\
\text { then offering victims a } \\
\text { way to pay-to-remove } \\
\text { the items. Additionally, } \\
\text { the defendant allegedly } \\
\text { posed as a woman on } \\
\text { Craigslist and collected } \\
\text { nude photos from people } \\
\text { with whom he } \\
\text { communicated. }\end{array}$ & $\begin{array}{l}\text { The FTC alleged a } \\
\text { violation of the Federal } \\
\text { Trade Commission Act (15 } \\
\text { U.S.C. § 45). } \\
\text { The parties settled. The } \\
\text { defendant agreed to delete } \\
\text { all information gathered } \\
\text { during the website's } \\
\text { operation and not display } \\
\text { any intimate images } \\
\text { without the depicted } \\
\text { individuals' affirmative } \\
\text { consent. }\end{array}$ \\
\hline $\begin{array}{l}\text { United States } v . \\
\text { Moore }^{192}\end{array}$ & $\begin{array}{l}\text { Moore operated a } \\
\text { pornographic website, }\end{array}$ & $\begin{array}{l}\text { Moore and Evens both pled } \\
\text { guilty to violating the }\end{array}$ \\
\hline
\end{tabular}

ATTORNEY GENERAL (June 8, 2015), https://oag.ca.gov/news/press-releases/attorneygeneral-kamala-d-harris-announces-three-year-sentence-cyber [https://perma.cc/3E58US37]. We found the following case references but could not obtain any associated documentation: Meyering v. Superior Court, No. A143682 (Cal. App. Ct. Dec. 9, 2014); State v. Meyering, No. CF-2014-793 (Okla. Dist. Ct. Feb. 25, 2014).

${ }^{191}$ Complaint, In the Matter of Craig Brittain, No. C-4564 (F.T.C. Dec. 28, 2015); Decision and Order, In the Matter of Craig Brittain, No. C-4564 (F.T.C. Dec. 28, 2015); FTC Approves Final Order in Craig Brittain 'Revenge Porn' Case, FEDERAL TRADE COMMISSION (Jan. 8, 2016), https://www.ftc.gov/news-events/press-releases/2016/o1/ftc-approvesfinal-order-craig-brittain-revenge-porn-case [https://perma.cc/4YAE-6KRL].

192 Man Who Operated 'Revenge Porn' Website Pleads Guilty in Hacking Scheme That Yielded Nude Photos from Google E-Mail Accounts, FBI (Feb. 25, 2016), https://www.fbi.gov/losangeles/press-releases/2015/man-who-operated-revenge-pornwebsite-pleads-guilty-in-hacking-scheme-that-yielded-nude-photos-from-google-e-mailaccounts [https://perma.cc/R8M2-GA5X]. 


\begin{tabular}{|l|l|l|}
\hline Case Name & \multicolumn{1}{|c|}{ Key Facts } & \multicolumn{1}{c|}{ Outcome } \\
\hline & $\begin{array}{l}\text { isanyoneup.com, similar } \\
\text { to the website operated } \\
\text { by Bollaert. To expand } \\
\text { the database, the } \\
\text { defendant allegedly } \\
\text { retained Evens to hack } \\
\text { into Gmail accounts to } \\
\text { find more photos. }\end{array}$ & $\begin{array}{l}\text { Computer Fraud \& Abuse } \\
\text { Act and identity theft.194 } \\
\text { Moore was sentenced to } \\
\text { thirty months in prison. } 195 \\
\text { Evens was sentenced to one } \\
\text { month for the CFAA count } \\
\text { and a mandatory two-year } \\
\text { term for the identity theft } \\
\text { count.196 Evens also had to } \\
\text { pay a fine of } \$ 2,000 \text { and } \\
\text { perform twenty hours of } \\
\text { community service. }\end{array}$ \\
& & $\begin{array}{l}\text { defendants } \text { The } \\
\text { \$147.50 in restitution to a } \\
\text { victim. } 198\end{array}$ \\
&
\end{tabular}

193 Press Release, Operator of 'Revenge Porn' Website Sentenced to 21/2 Years in Federal Prison in Email Hacking Scheme to Obtain Nude Photos, DEP'T OF JusT., U.S. ATT'Y OFFICE, C.D. CAL. (Dec. 2, 2015), https://www.justice.gov/usao-cdca/pr/operator-revengeporn-website-sentenced-2-years-federal-prison-email-hacking-scheme [https://perma.cc/82XW-XT8U].

194 Plea Agreement for Hunter Moore, United States v. Moore, No. CR 13-917-DMG (C.D. Cal. Feb. 18, 2015); Press Release, Operator of 'Revenge Porn' Website Sentenced to 21/2 Years in Federal Prison in Email Hacking Scheme to Obtain Nude Photos, DEP'T OF JusT., U.S. ATT'Y OFFICE, C.D. CAL. (Dec. 2, 2015), https://www.justice.gov/usaocdca/pr/operator-revenge-porn-website-sentenced-2-years-federal-prison-email-hackingscheme [https://perma.cc/8EFB-NYTX]; Press Release, L.A. Man Who Hacked into Email Accounts and Obtained Nude Photos for 'Revenge Porn' Website Sentenced to Federal Prison, DEP'T OF JUST., U.S. ATT'Y OFFICE, C.D. CAL. (Nov. 16, 2015), https://www.justice.gov/usao-cdca/pr/la-man-who-hacked-email-accounts-and-obtainednude-photos-revenge-porn-website [https://perma.cc/EN27-SALA].

195 Judgment and Probation/Commitment Order, United States v. Moore, No. CR 13-917DMG (C.D. Cal. Dec. 2, 2015).

196 Press Release, L.A. Man Who Hacked into Email Accounts and Obtained Nude Photos for 'Revenge Porn' Website Sentenced to Federal Prison, DEP'T OF JusT., U.S. ATT'Y OFFICE, C.D. CAL. (Nov. 16, 2015), https://www.justice.gov/usao-cdca/pr/la-man-whohacked-email-accounts-and-obtained-nude-photos-revenge-porn-website [https://perma.cc/4Y27-X4NK].

197 Andrew Blake, Charles Evens, 'Revenge Porn' Hacker, Handed 25-Month Prison Sentence, WASH. TIMES (Nov. 18, 2015),

http://www.washingtontimes.com/news/2015/nov/18/charles-evens-revenge-pornhacker-handed-25-month-/ [https://perma.cc/F3BD-PTJ8].

198 Judgment and Probation/Commitment Order, United States v. Moore, No. CR 13-917DMG (C.D. Cal. Dec. 2, 2015). 


\begin{tabular}{|l|l|l|}
\hline \multicolumn{1}{|c|}{ Case Name } & \multicolumn{1}{c|}{ Key Facts } & \multicolumn{1}{c|}{ Outcome } \\
\hline $\begin{array}{l}\text { Caraccioli v. } \\
\text { Facebook, Inc. } 199\end{array}$ & $\begin{array}{l}\text { An unknown actor } \\
\text { created a fake Facebook } \\
\text { account called “Franco } \\
\text { Caracciolijerkingman," } \\
\text { which included sexually } \\
\text { explicit photos and } \\
\text { videos of the victim, and } \\
\text { sent friend requests to } \\
\text { people in the victim's } \\
\text { network. }\end{array}$ & $\begin{array}{l}\text { The victim sued Facebook } \\
\text { privacy violations, IIED, } \\
\text { NIED, contract breach } \\
\text { and other claims. The } \\
\text { court granted Facebook's } \\
\text { motion to dismiss based } \\
\text { on both Facebook's user } \\
\text { agreement and Section } \\
\text { 23o. The appeals court } \\
\text { affirmed. }\end{array}$ \\
\hline
\end{tabular}

199 Caraccioli v. Facebook, Inc., 167 F.Supp.3d 1056 (N.D. Cal. 2016); Caraccioli v. Facebook, Inc., 2017 U.S. App. LEXIS 10040 (9th Cir. June 6, 2017). 